
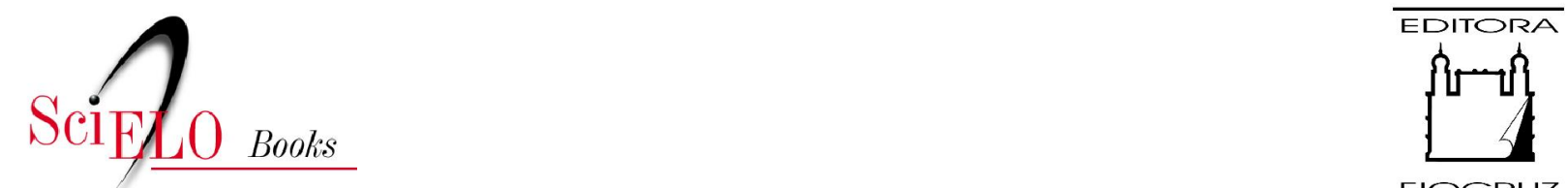

FIOCRUZ

\title{
Recursos humanos em saúde no Mercosul
}

\author{
Organização Pan-Americana da Saúde
}

Organização Pan-Americana da Saúde. Recursos Humanos em Saúde no Mercosul [online]. Rio de Janeiro: Editora FIOCRUZ, 1995. 147 p. ISBN 978-85-7541-398-2. Available from SciELO Books $<\underline{\text { http://books.scielo.org }>\text {. }}$

\section{(1) $(0)$}

All the contents of this work, except where otherwise noted, is licensed under a Creative Commons Attribution-Non Commercial-ShareAlike 3.0 Unported.

Todo o conteúdo deste trabalho, exceto quando houver ressalva, é publicado sob a licença Creative Commons Atribuição Uso Não Comercial - Partilha nos Mesmos Termos 3.0 Não adaptada.

Todo el contenido de esta obra, excepto donde se indique lo contrario, está bajo licencia de la licencia Creative Commons Reconocimento-NoComercial-CompartirIgual 3.0 Unported. 


\section{RECURSOS \\ HIIMANOS \\ EIV SAIUDE \\ NO MERCOSUL}

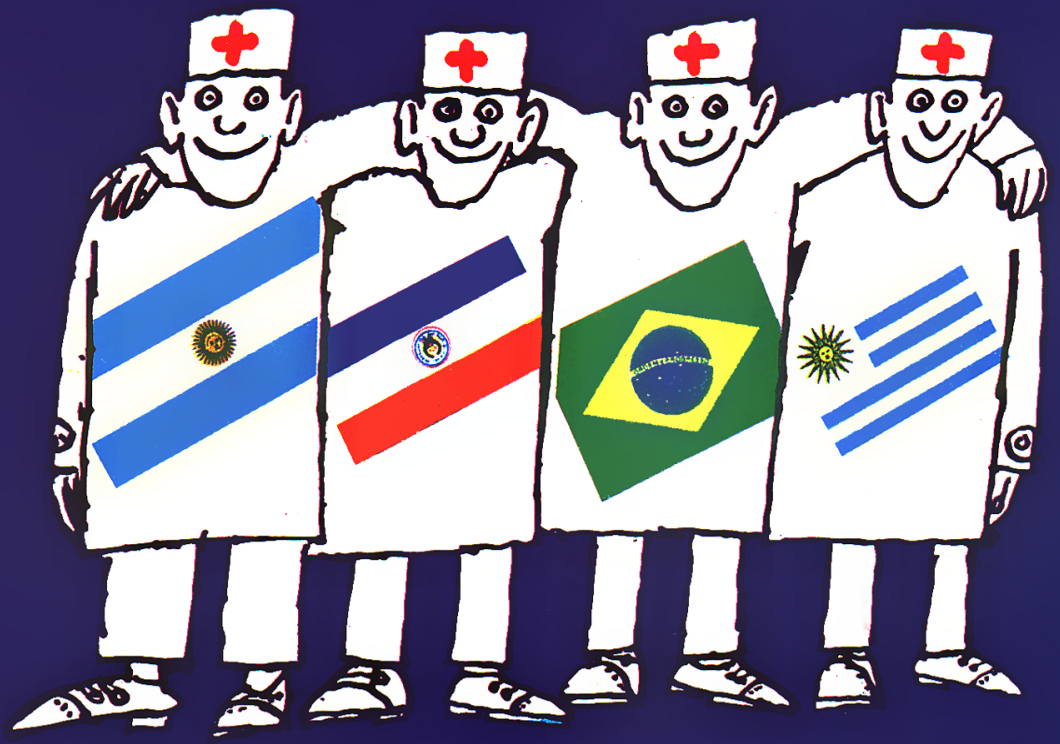

ORGANIZAÇÃo PAN-AMERICANA Da SAÚdE

ORGANIZAÇÃO MUNDIAL DA SAÚDE 
RECURSOS

HUMANOS

EM SAÚDE

NO MERCOSUL 


\section{FUNDAÇÃO OSWALDO CRUZ}

Presidente

Carlos Médici Morel

Vice-Presidente de Ensino e Informação

Paulo Marchiori Buss

\section{EDITORA FIOCRUZ}

Coordenador

Paulo Marchiori Buss

Conselho Editorial

Carlos E. A. Coimbra Jr.

Charles Pessanha

Hooman Momen

José da Rocha Carvalheiro

Luiz Fernando Ferreira

Paulo Gadelha

Paulo M. Buss

Sergio Goes de Paula

Zigman Brener

Coordenador Executivo

Francisco Edmilson M. Carneiro 
Organização Panamericana de Saúde Escritório Regional da OMS

Programa Especial de Desenvolvimento de Recursos Humanos

\section{RECURSOS}

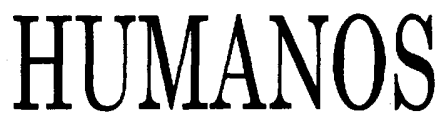

EM SAÚDE

\section{NO MERCOSUL}
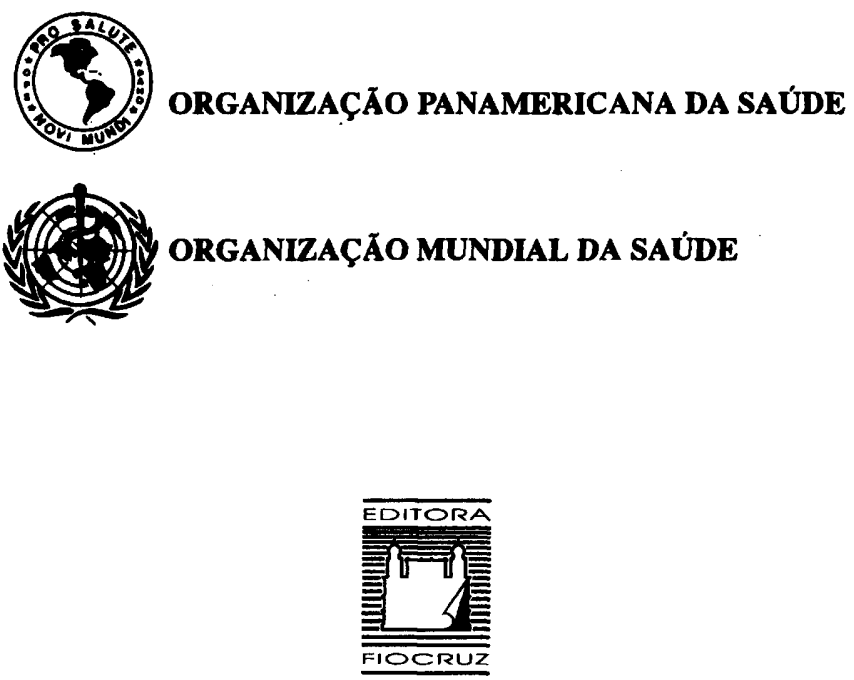
Copyright (C) 1995

Todos os direitos desta edição reservados à

EDITORA FIOCRUZ

ISBN: 85-85676-19-1

Revisão Técnica:

Célia Regina Pierantoni

Mário Roberto Dal Poz

Paulo Marchiori Buss

Capa:

llustração: Jaguar

Design: Carlos Prósperi

Projeto Gráfico: Heloisa Diniz

Editoração Eletrônica: Marilene Cardoso

Revisão: Marcionílio Cavalcanti de Paiva

Catalogação na Fonte

Centro de Informação Científica e Tecnológica

Biblioteca Lincoln de Freitas Filho

O 68r Organização Pan-Americana da Saúde

Recursos Humanos em Saúde no Mercosul/Organização

Pan Americana da Saúde.

Rio de Janeiro: Fiocruz, 1995.

147 p. tab.

1. Recursos Humanos em Saúde - Brasil. 2. Recursos Humanos em Saúde - Paraguai.

3. Recursos Humanos em Saúde - Argentina. 4. Recursos

Humanos em Saúde - Uruguai.

I. Título.

CDD - 20. ed. -331.11913621

1995

EDITORA FIOCRUZ

Rua Leopoldo Bulhões, 1480 - Manguinhos

21041-210 - Rio de Janeiro - RJ

Tel.: 590-3789 r. 2009

Fax.: (021) 280-8194 


\section{Autores}

- Alícia Arnau, Consultora Temporária da Organização Panamericana de Saúde, Paraguai.

- Mônica C. Abramzón, Professora da Universidade de Buenos Aires, Argentina.

- Pedro Brito, Consultor do Programa Especial de Desenvolvimento de Recursos Humanos da OPAS, Washington/USA.

- Francisco Eduardo de Campos, Consultor do Programa Especial de Desenvolvimento de Recursos Humanos da OPAS, Washington/USA.

- Mário Roberto Dal Poz, Professor do Instituto de Medicina Social da UERJ, Brasil.

- José Roberto Ferreira, Chefe do Programa Especial de Desenvolvimento de Recursos Humanos da OPAS, Washington/USA.

- Célia Pierantoni, Pesquisadora do Instituto de Medicina Social da UERJ, Brasil.

- Félix Rigoli, Diretor do Centro Assistencial do Sindicato dos Médicos, Uruguai.

- Rodolfo H. Rodriguez, Coordenador do Centro de Estudos de Recursos Humanos para a Saúde do Conselho de Médicos de Córdoba, Argentina.

- Joaquin Serra, Uruguai.

- Milagros Sugo, Uruguai.

- Tereza Christina Varella, Enfermeira do INAMPS e Pesquisadora do Instituto de Medicina Social da UERJ, Brasil. 



\section{Sumário}

Mercosul: um Processo de Integração

Rodolfo $H$. Rodríguez.. ......................... 9

O Campo dos Recursos Humanos em Saúde no Mercosul

Francisco Campos, Pedro Brito e Félix Rígoli.. ............... 31

Argentina: Situação dos Recursos Humanos em Saúde

Mônica C. Abramzón.

Estudo de Condições de Formação e Exercício Profissional em Saúde no Brasil

Mario Dal Poz e Tereza Christina Varella.. ................. 75

Formação e Mercado de Trabalho de Algumas Categorias

Profissionais de Saúde no Uruguai

Félix Rigoli, Milagros Sugo e Joaquin Serra,. . . . . . . . . . . . . . 107

Paraguai: Situação da Formação e Mercado de Trabalho na Área da Saúde Alicia Arnau e Célia Pierantoni ......................... 127

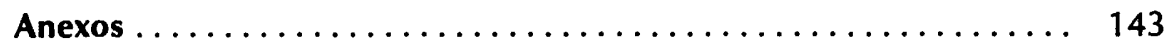

Tratado para a Constituição de um Mercado Comum entre a Argentina, o Brasil, o Paraguai e o Uruguai - Tratado de Assunção ........... 143

Regulamento da Comissão Parlamentar Conjunta do Mercosul. ..... 149 


\section{Mercosul: UM PROCESSO DE INTEGRAÇÃO}

Rodolfo H. Rodriguez

\section{ANTECEDENTES}

Em 1986, os presidentes do Brasil e da Argentina deram início a um processo de integração entre ambos os países, nos planos político, econômico e social. Logo em seguida, o Uruguai e, finalmente, o Paraguai, solicitaram participação no mencionado processo.

Desde então foi percorrido um longo caminho, que sem dúvida já resultou em benefícios concretos para os países-membros.

O primeiro efeito do processo de integração foi a modificação das hipóteses de conflitos sub-regionais. A repercussão dessa mudança fundamental nas políticas de defesa permitiu, por exemplo, uma associação estratégica entre a EMBRAER (fábrica brasileira de aviões) e a fábrica militar de aviões da Argentina. A nova concepção no tratamento dos problemas geopolíticos, por parte das empresas hidroelétricas em comum, facilitou o acesso ao crédito internacional para o prosseguimento dos projetos de Yaciretá Apipe e outras grandes obras.

O processo de integração econômica no campo da indústria aumentou significativamente o volume do intercâmbio comercial sub-regional e facilitou a implantação de projetos com financiamento privado binacional para a produção de bens comercializáveis com outros países.

Paralelamente, a solução do impasse de fronteiras entre Argentina e Chile com relação ao Canal de Beagle e o advento da democracia neste últi- 
mo país - e também no Paraguai - viabilizaram o tratamento sub-regional de diversos temas arquivados durante anos.

Dos diversos protocolos assinados entre o Brasil e a Argentina visando facilitar o intercâmbio de bens e serviços, destaca-se o de $\mathrm{n}^{\circ}$. 14. Por suas características, esse documento pode ser considerado o precursor do Tratado MERCOSUL.

\section{O TRATADO MERCOSUL}

Em 26 de março de 1991, na cidade de Assunção, capital da República do Paraguai, os Presidentes dos quatro países deram um passo decisivo para assegurar a continuidade desse processo, com a assinatura do TRATADO PARA A CONSTITUIÇÃO DE UM MERCADO COMUM entre os quatro países, deixando aberta a possibilidade (Art. 20) da incorporação de outros países que façam parte da ALADI!1 0 .

Na convicção de que o processo iniciado terá uma profunda repercussão em vários níveis - nas relações entre os signatários e entre esses e outros países, nas posições conjuntas a serem desenvolvidas em foros internacionais, no estabelecimento dos modelos de desenvolvimento em cada nação e na elevação do nível e da qualidade de vida dos povos da região -, a OPAS, por iniciativa de seu Diretor, decidiu participar ativamente do processo de integração, no campo de sua competência técnica!20.

$O$ presente documento de trabalho pretende fazer uma análise do tratado de integração do MERCOSUL e de seus efeitos diretos e indiretos sobre o setor Saúde, tal como a possibilidade de acesso dos países-membros à cooperação técnica e de intercâmbio entre eles.

Devido às características da dinâmica de integração e ao cronograma determinado pelos países, o presente documento focaliza o campo dos Recursos Humanos para a Saúde, principalmente porque nessa área surgirão as primeiras ações e reações setoriais em relação ao MERCOSUL.

\section{ANÁLISE DO TRATADO}

\section{Objetivos}

O principal objetivo é a constituição de um MERCADO COMUM que deverá estar em pleno funcionamento em 31 de dezembro de 1994.

A data escolhida tem implicações políticas e técnicas. As políticas visam assegurar que a totalidade do período de constituição desse Mercado Comum coincida com o mandato das atuais administrações, principalmente

1 A República da Bolívia solicitou sua adesão, em virtude dessa cláusula.

2 Guerra de Macedo, Carlyle: Mensagem do Diretor, OPAS, Washington DC, 1992. 
nos casos do Brasil e da Argentina!3Atém da propaganda política, a escolha dessa data pretende assegurar a unidade de critérios, garantindo assim o sucesso do Tratado. Do ponto de vista técnico, ela coincide com algumas datas já estabelecidas no quadro da ALADI para o decréscimo dos níveis de proteção - tarifas e impostos - sobre certos insumos e em alguns acordos firmados na reunião do GAT no Uruguai.

\section{Implicações}

São basicamente de quatro tipos:

a) Livre circulação de bens, serviços e insumos para a produção entre os países, através da eliminação dos direitos aduaneiros e das restrições não tarifárias, entre outros procedimentos.

b) Estabelecimento de uma tarifa comum no intercâmbio com países ou agrupamento de países não envolvidos e a coordenação de posições em foros econômico-comerciais regionais e internacionais.

c) Coordenação de políticas macroeconômicas e setoriais nos campos do comércio exterior, da agricultura, da indústria, da política fiscal, monetária, cambial e alfandegária, de transportes e comunicações e de outros campos a serem decididos.

d) Coordenação legislativa para a homogeneização do Direito, visando fortalecer o processo de integração.

Embora o texto sofra forte influência dos aspectos econômicos da integração, ele contém interessantes itens de caráter político, tais como a coordenação de posições de países fora do tratado e outros mercados comunitários e a coordenação de políticas macroeconômicas. Isso implica necessariamente no estabelecimento de novos acordos de natureza política, que certamente beneficiarão as populações dos países signatários do Tratado.

Do ponto de vista do setor saúde, a partir de uma visão moderna e integral do mesmo, a inclusão do conceito serviços entre os produtos de intercâmbio e a eliminação das restrições tarifárias (com a conseqüente reavaliação das não tarifárias) pressupõem a abertura de um camıpo de atividade de proporções interessantes.

O mesmo ocorre no que se refere à coordenação de políticas setoriais, por força do conceito abrangente da expressão "e outros campos a serem decididos".

3 O Presidente da República Federativa do Brasil, Itamar Franco, por exemplo, em seu discurso ao Congresso Nacional, comprometeu-se com a continuidade dos trabalhos e, poucos dias depois de sua posse, compareceu à reunião de rotina dos Presidentes do Tratado Mercosul. 
Finalmente, no campo do Direito, a revisão legislativa e a criação de novos foros de coordenação interparlamentar geram um ambiente sumamente fértil para a continuidade do projeto Democracia e Saúde ${ }^{4}$, que fora iniciado em 1990 pela OPAS e pela OEA (ver o Art. 24 do Tratado.).

\section{Fundamentação}

O Mercado Comum do Cone Sul tem como base a reciprocidade de direitos e obrigações entre os países-membros.

\section{As Etapas}

O Tratado prevê duas etapas: a primeira transcorre entre a assinatura do mesmo e o dia 31 de dezembro de 1994, e a segunda começa em 1 으 de janeiro de 1995.

Durante a primeira etapa, denominada "etapa de transição", o acordo prevê a adoção de um Regime Geral de Origem que estabelece as bases para o início das ações, um Sistema de Solução de Controvérsias e um conjunto de Cláusulas de Salvaguarda - estas últimas para dar espaço a alguns regimes alfandegários vigentes e permitir o ingresso do Uruguai e do Paraguai no Tratado.

A segunda etapa terá início no primeiro dia do ano de 1995 e será caracterizada pela plena vigência do conceito de livre mercado em sua acepção mais ampla (ver adiante).

Esse conjunto de normas tem especial valor técnico por estabelecer os percentuais anuais do decréscimo de impostos que será levado a cabo pelos países-membros, definir com clareza o que é um "produto nacional", determinar maior prazo (31 de dezembro de 1995) para a integração definitiva do Uruguai e do Paraguai, estabelecer as posições dos registros de produtos que terão sua proteção preservada até determinado grau etc.

\section{Os Instrumentos}

O tratado estabelece:

a) Um Programa de Liberação Comercial que consiste na redução linear, automática e progressiva de todas as restrições tarifárias e não tarifárias, visando chegar ao término da primeira etapa com tarifa zero para a totalidade dos bens, dos serviços e dos produtos que forem comercializados entre os países-membros.

4 O projeto Democracia e Saúde consistiu na reunião de parlamentares de diferentes países para a discussão de uma agenda comum, de temas vinculados à questão da saúde. No âmbito do Mercosul, realizou-se em Brasília (1991), sob os auspícios da OPAS, uma primeira reunião de parlamentares argentinos e brasileiros visando a análise de posições conjuntas a respeito de patentes de medicamentos. 

b) Um Programa Convergente de Coordenação de Políticas Macroeconômi- cas.
c) Um acordo de tarifa externa em comum.
d) Um sistema de adoção de acordos multilaterais de caráter setoria/5.

\section{A Administração}

O Tratado institui dois grandes órgãos para a administração do acordo:

a) O CONSELHO DO MERCADO COMUM, ao qual cabe a condução política e a tomada de decisões para assegurar o cumprimento dos objetivos e prazos estabelecidos. É integrado pelos Ministros da Economia e das Relações Exteriores dos países-membros, e reunir-se-á sempre que necessário. Além disso, há uma reunião anual com a presença dos Srs. Presidentes dos respectivos Governos.

b) O GRUPO MERCADO COMUM, que é o Órgão Executivo e será coordenado pelos Ministérios das Relações Exteriores. Ele executa as decisões tomadas pelo Conselho, dispõe sobre as normas e medidas para assegurar o cumprimento do programa de liberação comercial, a coordenação de políticas macroeconômicas e a negociação de acordos com países nãomembros. Dele dependerão os subgrupos de trabalho criados por força do Anexo 5 do tratado.

Esse órgão é integrado por quatro membros titulares e quatro suplentes (de cada país), com representação de: Ministério das Relações Exteriores, Ministério da Economia - ou equivalente - e Banco Central. Conta, ainda, com uma Secretaria Administrativa sediada na cidade de Montevidéu, que está funcionando desde 1992.

O Artigo 24, por sua vez, anuncia a intenção de constituir uma Comissão Parlamentar Conjunta do Mercosul, com o objetivo de facilitar a implementação do mesmo.

O Tratado é integrado por um conjunto de anexos, entre os quais vale destacar o no 5, que cria os subgrupos de trabalho dentro do âmbito do GRUPO MERCADO COMUM. São 11 comissões, que terão a seu cargo a coordenação das políticas macroeconômicas e setoriais. São elas:

5 Este ponto adquire importância fundamental como sustentação jurídica dos acordos que se estabeleçam entre as instituições do setor saúde. 


\begin{tabular}{lll}
\hline Subgrupo & 1 & Assuntos Comerciais \\
Subgrupo & 2 & Assuntos Alfandegários \\
Subgrupo & 3 & Normas Técnicas \\
Subgrupo & 4 & Política Fiscal e Monetária \\
Subgrupo & 5 & Transporte Terrestre \\
Subgrupo & 6 & Transporte Marítimo \\
Subgrupo & 7 & Política Industrial e Tecnológica \\
Subgrupo 8 & 8 & Política Agrícola \\
Subgrupo & 9 & Política Energética \\
Subgrupo 10 & Coordenação de Políticas Macroeconômicas \\
Subgrupo 11 & Relações Trabalhistas \\
\hline
\end{tabular}

Pela própria natureza dos assuntos, os subgrupos 3, 5, 7 e 8 têm componentes específicos, que exigem a participação técnica do setor saúde. No âmbito do Subgrupo 3 já foram iniciadas as atividades, com a colaboraçãa da OPAS ${ }^{6}$.

O Subgrupo 11 tem particular importância no campo dos Recursos Humanos. Entre outros temas, ele se ocupa das relações coletivas e individuais de trabalho, da livre circulação de trabalhadores, da formação profissional, do reconhecimento de habilitação profissional (títulos e diplomas) e de tudo que for relativo à Seguridade Social.

\section{EFEITOS DIRETOS E INDIRETOS SOBRE O SETOR SAÚDE}

Antes de estudarmos os efeitos e conseqüências que o processo de integração terá em nível setorial, bem como as contribuições que o próprio setor pode dar ao processo de integração, é necessário examinar a dimensão que damos neste documento ao conceito "setor saúde" e sua relação com o processo de desenvolvimento.

Em sua acepção estrita, costuma-se identificar o setor saúde como o conjunto de recursos humanos, materiais e econômicos que a sociedade destina principalmente à atenção de suas doenças e, em menor escala, à prevenção das mesmas. Sob esse ponto de vista, existe uma certa correspondência entre o setor e os denominados "serviços de saúde", seja qual for a natureza e a ação dos mesmos.

Mais ainda: em muitos países, o setor saúde ainda é identificado como

6 Com o apoio técnico e financeiro das representações da OPAS no Brasil e na Argentina, houve uma intensa colaboração na primeira etapa de conciliação de normas sanitárias entre os dois países. 
o sistema de que o Estado dispõe para a atenção aos doentes. Embora essa concepção esteja se modificando rapidamente, ainda subsiste, particularmente entre aqueles que têm como função o planejamento econômico do desenvolvimento, uma visão fundamentalmente assistencialista do setor, com tendência a tratá-lo de forma desagregada e a ignorar a natureza complexa e multifacetada do conhecimento e das capacidades nele enraizadas.

É nossa responsabilidade advertir sobre as conseqüências dessa conceituação restrita, gerando nossas próprias iniciativas e assumindo atitudes ativas que mostrem coesão setorial e clareza de objetivos.

Para isso, será necessário que as instâncias superiores da direção setorial, em nível dos países, assumam com firmeza seu papel e reclamem um espaço de maior relevância na discussão e na tomada de decisões sobre aspectos aparentemente extra-setoriais, porém importantes, pois atingem a situação da saúde.

A Conferência Sanitária Panamericana, em sua reunião de setembro de 1990, aprovou as novas "Orientações Estratégicas e Prioridades de Programa para a OPAS no quadriênio 1991-94", dentre as quais destaca-se, como eixo central, a colocação da Saúde no Processo de Desenvolvimento ${ }^{7}$.

Ali se enfatiza a necessidade de redimensionar o pensamento e a ação no campo da saúde, tanto em razão da estreita interdependência entre saúde e desenvolvimento humano, como pela contribuição que o setor pode levar ao progresso social dos povos da região.

O setor saúde pode:

a) Contribuir na busca da paz e na redução da violência.

b) Promover a integração e cooperação entre os países.

c) Fomentar a participação da cidadania responsável no processo de geração de melhores niveis de bem-estar social.

d) Propiciar maiores níveis de igualdade na instrumentalização das estratégias políticas e econômicas para o desenvolvimento, lutando para que a modernização do Estado implique na responsabilidade de assegurar à população a provisão de serviços de saúde adequados, e compatibilizar os processos de desenvolvimento com o necessário respeito ao meio ambiente.

e) Promover, na opinião pública e em todo o espectro político, um ambiente favorável ao processo de transformação do sistema de serviços de saúde, tornando-os mais eficazes e eficientes e com maiores níveis de igualdade.

7 Organização Panamericana de Saúde: "Orientações Estratégicas e Prioridades de Programa 1991/1994". OPAS, Washington DC, 126 págs., 1991. 
f) Propiciar a reorganização do setor para adequá-lo às novas modalidades de desenvolvimento.

g) Ampliar o espectro de relacionamentos intra e extra-setoriais, somando a vontade política e os recursos dos diferentes protagonistas públicos e privados, em busca de melhores níveis de saúde para a população.

h) Contribuir para o fortalecimento da democracia, esclarecendo os limites do direito do cidadão e contribuindo para a satisfação das necessidade sociais.

Estes e outros conceitos oferecem um referencial indispensável na hora de analisar os efeitos potenciais do MERCOSUL nas relações entre países no âmbito do setor saúde.

Identificamos três níveis de impacto:

\section{a) Nivel Político}

O Tratado MERCOSUl gera um conjunto de compromissos entre os países signatários que deve ser aproveitado para colocar em vigência a iniciativa sub-regional ${ }^{8}$, até agora de difícil viabilização.

Embora os principais envolvidos pareçam ser os Ministérios da Saúde (particularmente em seu papel regulador), abre-se um espaço extraordinário para a participação da Seguridade Social, das universidades, das sociedades profissionais, das empresas públicas e privadas do setor, dos Parlamentos, da esfera judicial e das próprias agências de cooperação internacionais que operam nos diferentes países.

Pelo grau de compromisso político assumido por outras áreas (Ministérios da Economia e das Relações Exteriores) no terreno concreto da instrumentalização das ações, abriu-se um espaço de trabalho no interior dos governos em que a saúde pode - por necessidade técnica - ampliar seu campo de participação dentro do que definimos conceitualmente como "setor" e suas vinculações com o processo de desenvolvimento.

Mesmo tratando-se de um acordo entre governos, de natureza eminentemente pública, ele exige a soma das vontades nacionais públicas e privadas para seu fortalecimento e sua continuidade. Assim, abre-se também aqui um espaço para o desenvolvimento de ONGs de natureza e composição variadas, onde os interesses da sociedade, acima das circunstâncias do momento político, acompanhem e fortaleçam o processo de integração, não

8 A iniciativa Cone Sul, promovida pela OPAS no quadro da estratégia de cooperação entre países, é um conjunto coordenado de ações em saúde entre os países da sub-região (Argentina, Brasil, Chile, Paraguai e Uruguai, com o acréscimo da Bolivia). Até o presente foi organizada uma agenda comum e um conjunto de intervenções setoriais - imunizações, saúde nas fronteiras etc. Os Ministros da Saúde e os grupos técnicos dos países signatários reúnem-se regularmente para coordenar suas políticas e programas de saúde. 
apenas nos aspectos comerciais (de mercado), mas também nos aspectos mais amplos da política social.

Finalmente, embora o tratado esteja restrito aos países signatários, vários de seus efeitos farão com que o Chile e a Bolivia manifestem interesse em participar dele. Esse aspecto deve ser levado em conta na área da Saúde, com o aproveitamento, inclusive, de certas conjunturas que demonstrem a necessidade imperiosa da cooperação entre todos os países da sub-região como, por exemplo, a eclosão do cólera.

\section{b) Nivel Técnico}

Neste nível, o impacto nasce, em grande parte, do próprio tratado, no que se refere à configuração e às responsabilidades dos subgrupos do GRUPO MERCADO COMUM. Mas será também uma conseqüência da visão política que o "setor saúde" adotar e mantiver em relação ao fenômeno da integração.

Aliás, os subgrupos que envolvem o setor saúde $(3,5,6,7,8,9$ e 11) exigem uma leitura técnica adequada, não apenas para estarmos preparados para responder a exigências específicas, como também para identificarmos nosso espaço natural dentro de cada um deles, fazendo valer nosso peso setorial $^{9}$.

\section{c) Nível Econômico}

Na dimensão setorial, cria-se uma oportunidade magnífica para dimensionar, quantificar e avaliar qualitativamente a contribuição que o setor saúde pode oferecer ao processo de integração em termos estritamente econômicos.

Além dos fundamentos éticos do discurso setorial (em função do valor do capital humano), será necessário iniciar rapidamente uma avaliação mais ampla da possível contribuição da saúde no processo de desenvolvimento.

Para isso, é imprescindivel identificar as ações, os agentes, o impacto do setor no mercado de serviços, a capacidade de expansão, a geração de empregos e outros fatores que dimensionem quantitativa e qualitativamente a oferta do setor.

Por outro lado, os Ministérios da Saúde deverão aproveitar a situação para fortalecer as áreas de participação direta (organização, normatização e controle) e gerar espaços apropriados para a participação ampla de grupos de trabalho multisetoriais que possam identificar e propor novos campos de ação dentro do processo de integração.

9 A reuniāo de Ministros da Saúde do Cone Sul, efetuada em Brasília em 1991, aprovou um acordo de constituição do Subgrupo Saúde dentro das estruturas do Grupo MERcosủl. Até o presente essa iniciativa não recebeu resposta por parte das autoridades nacionais. 
Isso virá favorecer o processo de fortalecimento dos níveis centrais dos Ministérios da Saúde e será útil para dar novo fôlego ao processo de transformação do sistema de serviços de saúde.

A Seguridade Social, de sua parte, deverá procurar mecanismos sub-regionais de extensão de proteção em suas coberturas e estudar os aspectos de política e direito trabalhista relacionados com a saúde.

\section{O PAPEL DA OPAS}

O papel da OPAS na esfera desse processo poderia ser concebido em quatro grandes áreas, sem prejuizo para a manutenção das atividades comuns e permanentes de cooperação que são levadas a cabo com os países. Essas quatro áreas são:

1 - Colaborar com os paises signatários e particularmente com as instituições do setor saúde na identificação das potencialidades do processo de integração no aperfeiçoamento da situação de saúde de todos os habitantes.

Para isso, é necessário:

- Elaborar análises estratégicas e formular propostas de trabalho com base em documentos técnicos abrangendo as diferentes áreas de interesse setorial.

- Fortalecer o processo de cooperação técnica entre os países da região e com países fora da região - priorizando, neste último caso, as relações com países da Comunidade Econômica Européia: Portugal, Espanha, França e Itália.

- Promover a constituição de foros de discussão regional intersetorial, vinculando instituições e técnicos ou especialistas de diferentes áreas de atividade, tanto públicas quanto privadas.

- Gerar uma comunicação técnica permanente para a difusão do conhecimento ligado ao processo de integração na área da saúde.

- Apoiar a criação e o fortalecimento de ONGs que tenham como objetivo o desenvolvimento e a consolidação da iniciativa.

2 - Vincular as atividades da iniciativa em saúde do Cone Sul com o processo de desenvolvimento e fortalecimento do Mercosul.

Isto implica:

- Identificar de uma nova agenda de ações comuns no âmbito de $\operatorname{TCC}^{10}$ entre os governos signatários do acordo.

- Unir os esforços de financiamento de atividades de TCC em projetos pre-

10 Do inglês Technical Cooperation among Countries (Cooperação Técnica entre Países), sigla adotada pelas Nações Unidas. 
viamente priorizados pelos governos, com metas, atividades e objetivos claramente definidos.

- Realizar reuniões de trabalho entre as representações da opAs de cada país para compatibilizar e priorizar uma agenda de cooperação técnica em nivel sub-regional.

3 - Fortalecimento institucional dos organismos de governo chamados a participar ativamente nos subgrupos de trabalho do CrUpo MERCOSUl.

Significa:

- Dar apoio técnico, bibliográfico e financeiro aos grupos de normatização como fator demonstrativo da capacidade do setor para dar respostas efetivas às necessidades do processo de integração.

- Numa segunda etapa, observar a necessidade de apoiar outras instituições públicas ou privadas para fortalecer a capacidade técnica do setor.

4 - Desenvolvimento de conhecimentos e capacidades no campo da comunicação social, para que o setor tenha destaque ante a opinião pública e dos próprios governos por sua capacidade de união e eficácia no processo de integração.

Vale dizer:

- Iniciar um processo diferente de cooperação, que terá por objeto a construção de uma imagem setorial ligada a um processo dinâmico e de alto valor político e econômico, como é o caso do processo de integração.

Suas formas e seus níveis de desenvolvimento serão analisados por especialistas na matéria, mas desde já é necessário assentar as bases para favorecer esse novo processo.

É claro que uma transformação dessa natureza requer uma revisão do próprio mecanismo da cooperação técnica com o país receptor e ao mesmo tempo uma forma diferente de relacionamento horizontal entre as representações da OPAS envolvidas.

5 - Criação de uma estratégia de cooperação específica no campo de formação, capacitação e dinâmica da força de trabalho nos Recursos Humanos em Saúde.

- Embora o campo da saúde não constitua uma atividade específica dentro das áreas de integração previstas no documento que estamos analisando, experiências prévias de integração de mercados, como foi o caso do Mercado Comum Europeu, demonstram que, com o avanço dos processos de integração econômica, coloca-se o problema da circulação da força de trabalho como componente dos processos de produção. No caso de mão-de-obra qualificada (profissionais, técnicos etc), a mobilidade fica in- 
dependente dos meios e das formas de produção, porém sem escapar a certos critérios gerais. Já existem antecedentes concretos, como ocorreu no caso de Argentina e Brasil com a contratação temporária de mão-deobra brasileira por firmas de capital binacional para desenvolver projetos na Argentina ${ }^{11}$.

Nesse ponto surgem de imediato alguns problemas a analisar, vinculados diretamente à nossa área de trabalho.

O primeiro problema decorre da necessidade de internacionalizar o alcance da atual legislação de proteção trabalhista ${ }^{12}$. Isso inclui, naturalmente, as forças de proteção da seguridade social médica e a necessidade de compatibilizar seguros e convênios de prestação de serviços com suas contrapartes nacionais.

Em outro nível, a contratação de profissionais de saúde, particularmente de enfermagem, intimamente ligada às diferenças de "preço" da mão-deobra em relação à valorização relativa das moedas nacionais, orientará o fluxo de recursos humanos qualificados em benefício de algumas regiões e em prejuízo de outras, requerendo o estabelecimento de reciprocidade de reconhecimento curricular e particularmente de mecanismos de habilitação e credenciamento.

Compatibilizar normas de prestação de serviços, procedimentos técni$\cos$ e, em algumas superespecialidades, reorganizar o "mercado de prestação de serviços" para dar-lhe eficiência em termos de custos, será uma necessidade crescente, principalmente nas áreas de fronteira e nas novas regióes internacionais de desenvolvimento econômico.

A "compra de capacidade" e a constituição de redes bi ou multinacionais de serviços estarão ligadas aos componentes de qualidade e custo da atenção médica, principalmente em algumas especializações (cirurgias de alta complexidade, plásticas restauradoras etc).

Por outro lado, a necessidade de formação de recursos humanos assumirá uma nova dimensão, ora expressa em termos de mercados nos quais alguns países, pela qualidade da oferta ou pelo baixo custo relativo, assumirão o papel de formadores (Uruguai?) e outros, o de consumidores (Argentina, Brasil?).

As novas áreas de desenvolvimento que se mostrem mais dinâmicas, em termos de crescimento econômico, atrairão mais recursos assistenciais do que as regiões mais afastadas do processo.

11 Recentemente, a UOCRA (União Operária da Construção da República Argentina) denunciou a contratação, fora dos limites da legislação trabalhista argentina, de trabalhadores paraguaios e bolivianos por empresas nacionais e internacionais da área de comunicações. Clarín, Bs. As., janeiro de 1993.

12 Uma proposta concreta nesse sentido é tomar como referência os convênios básicos da OIT que, até o presente, não foram subscritos por todos os países integrantes do Tratado. 
Mais uma vez, isso afetará a distribuição dos recursos humanos e obrigará os países a elaborarem projetos comuns de incentivos ao trabalho nas áreas prejudicadas, que em muitos casos coincidirão com as chamadas fronteiras excluidas.

Definitivamente, o campo dos recursos humanos constituirá um terreno de grande mobilidade e impacto, sobre o qual devemos desenvolver uma estratégia adequada de cooperação sub-regional.

\section{MERCOSUL: UM MERCADO COMUM DE TRABALHO}

Do ponto de vista etmológico, "mercado" continua sendo o lugar ou espaço em que vendedores (ou produtores) convidam eventuais interessados (consumidores) a adquirir seus produtos ${ }^{13}$.

Atualmente utiliza-se uma acepção extensiva do conceito, referindo-se a âmbitos físicos, jurídicos, normativos ou informáticos onde é possível comercializar desde capitais e produtos até marcas e direitos de utilização.

Nesta acepção, um mercado obedece a uma série de fatores condicionantes: os que se relacionam com a atividade de produzir (volume, tipo, qualidade, distribuição, preço, etc) e aqueles que caracterizam a demanda (necessidade, capacidade econômica, leis, informação etc).

A atividade regulamentadora por parte dos governos em relação aos diferentes mercados tem especial impacto no comportamento dos agentes.

Desde a sua capacidade de intervenção nos custos de produção (através de impostos ou subsídios) até o controle da circulação de produtos, e, mais diretamente, a modificação dos preços relativos dos mesmos (imposto de consumo), o Estado exerce (ou, pelo menos, pode exercer) uma influência decisiva sobre o comportamento dos mercados.

Essa ação do Estado materializa-se no contexto de um quadro jurídico e normativo.

Quando essa atividade é exercida dentro dos territórios nacionais, os preceitos básicos para a construção de um mercado podem ser resumidos no que doutrinariamente é reconhecido como o exercício das cinco liberda$\operatorname{des}^{14}$ :

- A livre circulação de mercadorias, com a abolição de barreiras alfandegárias dentro dos países.

- O livre estabelecimento da força de produção em qualquer lugar do território nacional.

13 Direito Comunitário, Lisboa, , $2^{\text {a }}$. Edição. Fundação Calouste Gulbekian, p. 439, 1988.

14 Batista, L. O.: Assuntos Comerciais em Documentos do Instituto de Estudos Avançados da Universidade de São Paulo. (Mimeo), 30 págs. Apresentado no Seminário Mercosul BRA/Fase I, 1992. 
- A livre circulação da força de trabalho (os trabalhadores) dentro do espaço nacional.

- A livre circulação de capitais baseados em moedas únicas de circulação legal e reconhecimento nacional.

- A livre competição, através de regras igualitárias para todos os produtores, que assegurem a possibilidade, no mínimo, de produção a custo igual.

Pelo menos do ponto de vista teórico, e lançando mão de uma simplificação aceitável neste tipo de trabalho, pode-se dizer que a integração de mercados entre países deve basear-se na extensão das cinco liberdades ao conjunto das populações consideradas dentro do território a ser integrado.

Até aqui, analisamos as duas fases vigentes dentro do processo de construção do mercado comum: a primeira, caracterizada pelos acordos prévios que culminaram na Ata de Assunção e a atual, que pressupõe a redução progressiva de impostos sobre produtos, num cronograma fixado que desembocará na eliminação de barreiras tarifárias a partir de 1995.

A essa fase de livre comércio deverá suceder uma fase de mercado comum, na qual será acrescentada a livre circulação dos chamados fatores de produção, isto é, capital e trabalho.

As fases posteriores num processo de integração (a união econômica e a união monetária) não estão, por enquanto, na mira dos países envolvidos.

Isto quer dizer: tanto do ponto de vista da inclusão dos serviços entre as mercadorias de livre circulação, quanto do ponto de vista da necessidade de extensão da liberdade de trabalho, a questão dos recursos humanos torna-se um importante capítulo do processo, merecendo uma análise mais detalhada por parte dos diversos setores que compõem a nova sociedade a ser integrada.

\section{O MERCOSUL E OS RECURSOS HUMANOS}

"As tendências demográficas atuais, o progresso científico e tecnológico, a crescente luta por espaços de competição no comércio internacional e a diminuição da importância estratégica da importação e exportação de produtos primários - nada disso constitui grande ameaça às bases econômicas dos países do futuro MERCOSUL. Pelo menos, não tanto quanto a deplorável situação do mercado de trabalho regional, onde falta mão-de-obra qualificada e sobram trabalhadores com pouca ou nenhuma habilitação" 15.

Uma maneira original de qualificar a crise de nossos países não se limita à análise da situação das balanças comerciais nem ao incrivel volume da divida externa acumulada, mas abrange também a extraordinária concentra-

15 Scuro Neto, P. Instituto de Estudos Avançados da USP, em Seminário sobre Mercosul BRA/Fase I. Opus cit., 19 págs., 1992. (Mimeo) 
ção de renda e o número cada vez maior de famílias que lutam para encontrar um lugar no mercado de trabalho - que, por sua vez, caracteriza-se por seus salários baixíssimos.

Um mecanismo para reverter essa situação exige a elevação do nível de vida de grande parte da população, diminuindo, através do aumento da produtividade, o valor dos bens e serviços que o trabalhador consome.

Isso só será possível investindo-se na qualificação da mão-de-obra e provocando mudanças profundas na organização do trabalho.

No entanto, paradoxalmente, o mercado não foi o maior causador dessas transformações, como demonstra o fato de que, tanto no caso dos países do sudeste asiático quanto no dos que integram o Mercado Comum Europeu, o Estado tem sido o agente e - em muitos casos - o instrumentalizador das transformações na qualificação dos recursos humanos.

As experiências desenvolvidas na Alemanha, na Dinamarca e no Japão, onde as empresas contribuem para um fundo de educação administrado pelo Estado para a qualificação de mão-de-obra, ou ainda as da Suécia, da Ir-. landa e de Cingapura, onde a contribuição toma a forma de uma percentagem $(2,5 \%)$ sobre a folha de pagamento para esse mesmo fim, demonstram a necessidade da intervenção estatal no planejamento estratégico do desenvolvimento.

Se isso acontece no plano da capacitação técnica de nível pré-terciário, algo semelhante, embora com características próprias, acontece no mercado de trabalho profissional dos países que integram o MERCOSUL.

O grupo de especialistas convocado pelo Programa Regional de Desenvolvimento dos Recursos Humanos para a Saúde, da OPAS, em Assunção, Paraguai, para a análise dessa problemática, identificou cinco áreas de interesse para a investigação e o desenvolvimento dentro do processo de integração regional. São elas:

- Formação e capacitação de mão-de-obra.

- O mercado de trabalho.

- A planificação dos recursos humanos.

- A regulamentação e a normatização setoriais.

- As características dos modelos de prestação de serviços e seu financiamento.

Em cada uma dessas áreas, a transição de critérios ordenadores de mercados nacionais para critérios de mercado sub-regional significará profundas transformações, que exigirão uma nova capacidade de resposta, gerando, por sua vez, grandes conflitos de interesses.

São esses interesses que estão regendo a dinâmica de trabalho do campo de recursos humanos no processo de integração.

Os governos nacionais parecem, até o presente, motivados por esse assunto, que, por razões óbvias, constituiu o eixo do interesse das associações de trabalhadores e de profissionais liberais. 
Os sindicatos de trabalhadores e suas organizações terciárias (as confederações) realizaram algumas reuniões com intercâmbio de informações, tentando conciliar as posições diante dos desafios colocados pela integração ${ }^{16}$.

Os reitores de universidades nacionais tiveram um primeiro - e único encontro no Brasil (São Paulo, 1992), quando ficou estabelecida uma agenda mínima de trabalho, que neste momento está sendo analisada por cada um deles para sua efetiva instrumentalização. A Universidade Nacional de Córdoba, por sua vez, sediou em setembro de 1992 um encontro entre Universidades da Argentina, do Uruguai e do Sul do Brasil, intitulada "A Problemática da Universidade no MERCOSUL". As áreas de trabalho identificadas nesse encontro foram ${ }^{17}$ :

a) A transferência tecnológica ao setor de produção.

b) A qualidade no sistema universitário.

c) A normatização do currículo e a criação de normas em comum para o exercício profissional.

Alguns institutos de pesquisa dentro das universidades avançaram ainda mais, realizando seminários como o que citamos no presente documento (USP/Brasil, Instituto de Estudos Avançados, UNC/Argentina, Centro de Estudios sobre Derecho de la Seguridad Social).

Entidades empresariais, particularmente na Argentina e no Brasil, contando com o apoio dos Ministérios da Economia e das Relações Exteriores, realizaram encontros em que assuntos referentes à força de trabalho foram mencionados paralelamente.

Onde, porém, a mobilização é sem dúvida mais intensa é no campo das organizações profissionais (deontológicas ou gremiais) dos países envolvidos.

Em alguns casos, como o do Sindicato dos Médicos do Uruguai e o Conselho Federal de Medicina do Brasil, foram promovidas reuniões internacionais (em Montevidéu, Uruguai; Córdoba, Argentina; Foz do Iguaçu, Brasil); em outros casos, foram assinados convênios de cooperação bilateral para dar início a trabalhos sistemáticos visando a análise de incumbências, a formação e habilitação de profissionais (Conselho de Médicos da Província de Córdoba, Argentina, com o Conselho Federal de Medicina do Brasil). A julgar pelos dados disponíveis, são os profissionais da engenharia que se en-

16 A reunião mais recente realizou-se em Buenos Aires entre representações dos trabalhadores do Brasil, do Uruguai e da Argentina. A agenda incluiu a análise das políticas de privatização de empresas públicas e o regime trabalhista entre os três países. Cadernos da Cut. $n^{2} .8$, 1993.

17 Hoy la Universidad: Ano II $\mathrm{n}^{\circ}$. 20. Outubro-novembro de 1992. Editora da Universidade Nacional de Córdoba, Córdoba, República Argentina. 
contram em etapas mais avançadas de organização de critérios para a força de trabalho setorial.

A reunião convocada pelo Programa Regional de Desenvolvimento dos Recursos Humanos da OPAS (18 a 20 de novembro de 1992) em Assunção, Paraguai, à qual já nos referimos, contribuiu para a identificação de um conjunto de áreas de interesse específico para o desenvolvimento do conhecimento e o intercâmbio de experiências entre instituições vinculadas especificamente ao setor saúde.

Como resultado dessa reunião, a OPAS, através de suas representações, realizou uma copilação de informações básicas que faz parte da presente publicação e que cumprirá a importante função de permitir a identificação dos problemas concretos que surgirão ao longo do processo de integração.

O mencionado grupo de trabalho foi unânime em reconhecer que "o campo dos recursos humanos na saúde sofrerá, nesse processo, o impacto conjunto das transformações surgidas no desenvolvimento dos processos produtivos, nos serviços de saúde, no setor educativo e no movimento da força de trabalho setorial".

No primeiro caso (desenvolvimento de processos produtivos), o setor saúde terá importante participação na elaboração de normas e padrões de qualidade para os produtos que circularão livremente entre os países-membros, assim como para aqueles que resultem de produções integradas para outros mercados.

Nesse nivel, a alimentação, a química geral, a química fina e os insumos tecnológicos para a saúde constituirão as áreas mais destacadas. Não podemos esquecer que, eliminadas as restrições de natureza econômica, as denominadas barreiras não tarifárias adquirem grande importância.

Em relação ao segundo aspecto (serviços de saúde), destacam-se as questões inerentes aos processos assistenciais, as coberturas de atendimento médico por seguradoras privadas internacionais, as competência de graduação e pós-graduação e o comportamento de um mercado regional em termos de captação ou exclusão de recursos humanos e seu impacto sobre os serviços públicos e particulares.

Com relação ao terceiro componente (o sub-setor Educação), será necessário analisar as questões ligadas ao processo formativo em seus diferentes aspectos:
a) Currículo.
b) Qualificação docente.
c) Grau de abertura das universidades.
d) Reconhecimento de diplomas. 
Como conseqüência do processo de integração, também serão afetados os aspectos relativos à capacitação de pós-graduação, no que se refere a:

a) Exigências do serviço social obrigatório.

b) Habilitação de instituições e processos de capacitação.

c) Reconhecimento de especializações - habilitação.

d) Incumbências e

e) Âmbito e processos de controle do exercício profissional.

Finalmente, será necessário analisar o impacto sobre os recursos humanos produzido pela criação de um mercado de trabalho regionalizado, tanto em termos de sua mobilização quanto nos aspectos inerentes à sua utilização por parte dos serviços públicos e privados dos diferentes países.

\section{INSTRUMENTOS DA INTEGRAÇÃO NO CAMPO DOS RECURSOS HUMANOS EM SAÚDE}

O Tratado de Assunção prevê aspectos instrumentais que é conveniente analisarmos sob a ótica adotada no presente documento de trabalho.

Convém recordar, de início, que os protocolos de integração (Anexo no. 5 do tratado) adquirem categoria de legislação comum ao serem ratificados pelos respectivos parlamentos nacionais. Daí a importância dos acordos entre os governos.

No entanto, no campo dos recursos humanos existem divergências profundas com relação à natureza jurídica das instituições do subsetor e com relação ao âmbito político-jurisdicional onde são exercidos seus direitos e suas incumbências.

Assim, por exemplo, as universidades argentinas gozam de um nível de autonomia em suas decisões acadêmicas que as transformam quase num foro extraordinário. Será preciso, portanto, prever a necessidade de acordos de instrumentalização de políticas que ajustem os aspectos operacionais (interinstitucionais) aos limites jurídicos criados como conseqüência do processo de integração.

O mesmo ocorre com o regime de controle do exercício profissional, que na região estende-se desde o caso de um limitado exercício estatal do controle (Paraguai) até a descentralização por províncias em entidades autárquicas administradas pelos próprios interessados, como é o caso do Brasil e da Argentina.

Nesse último país, por sua vez, o fato de as províncias - ou estados não delegarem o poder de Polícia Sanitária cria uma situação particular, onde não existe um organismo nacional com capacidade de agir como representante de cada província ou estado. 
Esses tipos de problemas instrumentais ganharão uma vasta legislação e normatização, que se expressarão em convênios interinstitucionais de alcance particular.

Não seria de estranhar, portanto, o surgimento de movimentos e tendências no interior dos países que - como tentativa de proteção corporativa ou, ao contrário, por interesse em aplicar ao subsetor a lógica do mercado introduzam novos elementos de conflito que afetem o processo de integração que se deseja levar a cabo.

Nesse sentido, é importante observar as experiências em curso, tanto na Comunidade Européia como no NAFTA, e prever as influências que essas associações terão no processo MERCOSUL ${ }^{18}$.

O processo de integração terá conseqüências também nos aspectos ligados ao planejamento setorial. Não apenas porque os planos nacionais de desenvolvimento já estão prevendo as conseqüências macroeconômicas da criação de um mercado comum ${ }^{19}$ em relação ao impacto sobre a mobilidade e o emprego da população economicamente ativa, mas porque começa a desenvolver-se - embora incipiente - um mercado secundário de ofertas educativas para a sub-região ${ }^{20}$.

Nesse sentido, é preciso levar em conta que o Acordo de Integração traduz as tendências dos grandes grupos econômicos para ampliar seus mercados e atingir níveis de produção competitivos em escala supranacional. Os fatores econômicos, territoriais e de concentração de consumidores, que sustentam o crescimento produtivo desses grupos, terão impactos diferentes segundo os setores sociais considerados e as áreas que fiquem incluídas ou excluídas na nova dinâmica do mercado.

A essa altura dos acontecimentos, fica claro que existe uma tendência ao incremento da acumulação de riqueza em grupos de alta capacidade de consumo, e, por sua vez, à concentração dos mesmos em áreas escolhidas.

Os eixos Buenos Aires-São Paulo e Montevidéu-Assunção marcarão os limites reais do mercado consumidor de bens e serviços, ao passo que as áreas excluídas tornar-se-ão os novos (antigos?) provedores de matéria-prima e insumos, acentuando as desigualdades regionais já existentes.

Nesse contexto possível, a descentralização do sistema de serviços de saúde corre o risco de aprofundar a marginalização das pequenas e médias localidades da periferia dos países do MERCOSUL, privando-as dos benefícios do desenvolvimento incentivado pela dinâmica do novo mercado regional.

Para prevenir essas indesejadas conseqüências do processo de integra-

18 Ver Orzack, L. The Ceneral Systems Directive. Education and the Liberal Professions.

19 Paraguai: Secretaria de Planejamento, Presidência da Nação, Plano Nacional de Desenvolvimento 92-94.

20 Projeto de Mestrado na Escola Nacional de Saúde da FIOCRUZ, no Brasil, e Mestrado em Administração de Serviços de Saúde da Universidade Nacional de Córdoba, na Argentina. 
ção, é preciso desenvolver uma nova capacidade estratégica de planificação, que terá necessariamente uma visão regional.

Retirar do Estado sua função regulamentadora, produto das políticas de ajuste em execução, pode significar, no campo da saúde, uma manifesta acentuação das desigualdades e injustiças existentes.

Também nesse sentido é imperativa a produção de novos conhecimentos, que agora terão uma dimensão mais ampla do que a dimensão histórica.

$\mathrm{O}$ apoio dos organismos internacionais aos projetos cooperativos de pesquisa que envolvam as instituições setoriais dos diferentes países-membros aparece nesse contexto como um investimento de alto potencial de rentabilidade.

\section{COMO CONCLUSÃO}

Aos dois anos de sua vigência, o projeto MERCOSUL ingressou numa etapa de múltiplas dificuldades e crescente ceticismo quanto à realização das propostas contidas no Tratado de Assunção ${ }^{21}$.

Apesar disso, o cronograma de retirada de impostos vem sendo cumprido - $68 \%$ até agora - e existe uma crescente dinâmica de integração no campo das empresas líderes em diferentes campos da produção.

Tudo isso leva à conclusão de que, além da vocação política repetidamente alegada pelos governos dos países envolvidos, os avanços e retrocessos que surgem na etapa presente representam as influências e os interesses dos grupos econômicos comprometidos no processo.

Os investimentos em curso, as fusões empresariais, a criação de um incipiente mercado de capitais e os efeitos já alcançados pelo processo de destarifação em termos de intercâmbio comercial - tudo isso direciona o processo e o mantém distante das dificuldades identificadas.

A institucionalização do processo, com a instalação do GRUPO MERCOsul em sua Secretaria Executiva de Montevidéu (Uruguai), está produzindo, nos diferentes grupos de trabalho, permanentes acordos (protocolos adicionais) que fortalecem o processo e criam, de fato, um novo corpo de legislação sobre o qual se assentará a estrutura jurídica do MERCOSUL. Até agora, diversas resoluções (protocolos adicionais) foram aprovadas durante as deliberações do GRUPO MERCOSUL diretamente vinculadas ao campo da saúde 22 .

Dada a fase de livre comércio que atravessamos, nenhum governo ou grupo empresarial manifestou interesse pela aplicação ampla da terceira condição de liberdade que caracteriza a construção de um mercado: a criação de um mercado de trabalho.

21 Silvero Silvagni, R.: em ABC, edição de 28 de fevereiro de 1993, Assunção, Paraguai.

22 Ver as Resoluções $N^{0 s}$. 55, 56, 60, 61 e 62 da VIII Reunião de Trabalho do Grupo Mercado Comum. Montevidéu, 1993. 
No entanto, como já descrevemos, já começam a surgir atividades de grupos e instituições com interesse nessa problemática; lentamente - e às vezes sem uma agenda explícita - esses grupos procuram posicionar-se na prevenção dos efeitos setoriais da política de integração.

$E$, portanto, o momento adequado para que os organismos internacionais e as instituições nacionais do setor comecem a desenvolver atividades conjuntas visando compatibilizar interesses e desenvolver novos conhecimentos que garantam um processo de integração fluido e proveitoso no que diz respeito à saúde de nossa população e às ações que competem ao setor.

Já foram identificadas, particularmente no campo dos recursos humanos para a saúde, diversas áreas resultantes do interesse das instituições do setor em suas diversas expressões públicas e particulares.

A copilação de informações iniciada pelas representações da OPAS nos quatro países constituirá, nesse sentido, uma contribuição substancial ao processo de discussão iniciado.

No futuro imediato, novas atividades, que merecem ser acompanhadas pela OPAS, virão juntar-se às já realizadas e às que estão em curso.

A temática resgatada em termos de áreas de interesse na reunião de Assunção contribuirá, sem dúvida, para a construção de uma Agenda Setorial Regional, e permitirá que os esforços de pesquisa e cooperação sejam direcionados em sentido positivo. 


\title{
O campo dos Recursos HUMANOS PARA A SAÚDE NO MERCOSUL
}

\author{
Francisco Campos \\ Pedro Brito \\ Félix Rigoli
}

O Programa Especial de Desenvolvimento de Recursos Humanos da OPS/OMS vem promovendo há dois anos uma série de estudos e grupos de trabalho, objetivando responder a um conjunto de questões derivadas do processo de integração do MERCOSUL.

Os avanços que têm se verificado neste processo, nos últimos anos, têm produzido inquietudes e preocupações entre os diversos atores institucionais e sociais do setor saúde e do campo de recursos humanos nos quatro países signatários.

Está presente, para tais atores, a experiência da Comunidade Econômica Européia e as dificuldades que teve de enfrentar.

Um primeiro sinal destas preocupações foi recebido do Sindicato de Médicos do Uruguai, preocupado com os possiveis desequilíbrios derivados da livre circulação de profissionais na sub-região.

Logo receberam-se pedidos de cooperação de outras entidades gremiais e de secretarias municipais e estaduais das zonas limítrofes, em algumas das quais já se estavam verificando deslocamentos e outras situações não previstas. 
Isto levou o Programa a definir um plano de trabalho centrado na realização de estudos visando prevenir eventuais desajustes e situações problemáticas.

A OPS tem permanecido alerta, acompanhado os avanços diplomáticos e comerciais do processo de integração e procurando articular estratégias e projetos da Iniciativa do Cone Sul - que reúne periodicamente os Ministros de Saúde da sub-região e Chile - com as possibilidades do MERCOSUL.

A Terceira Reunião de Ministros de Saúde do Cone Sul, realizada em junho de 1991, em Brasília, permitiu aos países do MERCosul firmar um acordo em que propõem ao Grupo Mercado Comum a criação de um subgrupo "destinado a atender às questões derivadas do processo de integração que tenham relação com a saúde das pessoas e o meio ambiente e com os aspectos sanitários do fluxo de bens e serviços".

Nesta linha de ação, o Programa de Desenvolvimento de Recursos Humanos começou um trabalho de reflexão a respeito do impacto prospectivo do acordo sobre a dinâmica do mercado de trabalho em saúde na região, incluindo aspectos da preparação de pessoal. Um Grupo de Trabalho reunido em Assunção (novembro de 1992), formado por representantes dos Ministérios de Saúde e Representações da ops nos quatro países e na Bolívia, examinou os possíveis desenvolvimentos no campo dos recursos humanos e, ao mesmo tempo, constatou a insuficiência de dados para que se pudessem aprofundar as conclusões.

Foi proposta então a realização de quatro estudos subsetoriais de recursos humanos nos países signatários, com o objetivo de colher evidências empíricas para a análise proposta.

Uma vez realizados os estudos, promoveu-se uma reunião de trabalho em Montevidéu, mais uma vez com representações dos quatro países, com o objetivo de identificar uma agenda de problemas e as principais áreas de interesse que pudessem reorientar a cooperação técnica em recursos humanos para esta sub-região.

O presente documento reúne e sintetiza as discussões do Grupo e as informações colhidas. O objetivo explícito é apresentá-lo à consideração e análise das direções do setor saúde, tanto dos governos da sub-região como das instituições interessadas e da própria Organização, a fim de promover a tomada de consciência e o debate.

O propósito último não é outro senão contribuir para a prevenção de desequilíbrios e dificuldades e preservar o desenvolvimento dos serviços e recursos humanos em saúde, no marco de critérios de eqüidade, qualidade, eficácia e eficiência.

O Programa Especial de Desenvolvimento de Recursos Humanos da OPS/OMS promovem, assim, estudos nacionais sobre a situação dos recursos humanos nos quatro países do acordo. 
O Grupo de Trabalho identificou, com base nos estudos e nas principais preocupações explicitadas pelos atores considerados, um conjunto de áreas de interesse que se resumem a seguir.

Sobre a base da informação colhida se apontará, em seguida, um conjunto de situações e tendências problemáticas que, na opinião do Grupo de Trabalho, caracterizam a situação dos recursos humanos de saúde na sub-região.

\section{FORMAÇÃO DE PROFISSIONAIS DE SAÚDE}

Um obstáculo previsível dos processos de integração são as inevitáveis e históricas diferenças existentes entre os sistemas de formação profissional nos países signatários. No caso dos médicos, contrapor-se-ão os diferentes desenvolvimentos curriculares de muitas dezenas de escolas com modelos formativos específicos para brindar um produto aparentemente uniforme.

Porém, apesar da complexidade deste caso, será sem dúvida mais simples que a normatização do que se há de entender no MERCOSUL por "enfermeira" ou "técnico de serviços auxiliares", para os quais existem inclusive diferenças de definição no interior de cada país.

Muitas das universidades públicas dos países debatem-se entre os problemas orçamentários e a superpopulação estudantil, deixando pouco espaço para o trabalho de preparação para os processos de integração. Até agora, tais esforços têm-se resumido aos procedimentos gerais de revalidação de títulos estrangeiros, em geral embaraçosos devido às dificuldades intrínsecas já mencionadas e pela inexistência de um marco geral favorecedor, pelo que o intento de revalidação é visto como uma ameaça à Universidade Nacional.

Dever-se-á ter em mente a experiência do General Systems Directive (CSD), documento que rege o exercício profissional na Comunidade Européia, que define normas muito liberais de intercâmbio profissional. Mas deve-se assinalar que a sua implementação foi praticamente forçada pelos acontecimentos políticos, uma vez que os acordos profissão por profissão resultaram altamente burocráticos e seguramente não se teriam completado (ver Orzack, L.: The Ceneral Systems Directive: Education and the liberal professions).

Talvez a circunstância da integração reative, sobre outras bases, as instâncias de planejamento educacional, agora com um conteúdo regional, onde ele atue como um sistema de monitoramento da produção e distribuição de profissionais e se vincule a sistemas de informação de mercado de trabalho em nivel subregional.

É neste sentido que adquirem importância as diferentes condições de acesso às instituições de formação superior vigente nos países e até entre regiões. As restrições já em vigência através de numerus clausus, vestibulares e 
cobrança de matrículas significativas, já estão produzindo migrações de estudantes para aqueles centros de menores barreiras, o que sem dúvida há de se acentuar criticamente a partir da perspectiva de livre prática profissional entre os países.

A fim de se antecipar às reações defensivas que inevitavelmente se gerarão, as Escolas afetadas pelos intercâmbios devem definir ações conjuntas, sendo imprescindivel o relançamento do antes mencionado planejamento educacional, agora em caráter regional.

\section{Deterioração da capacidade docente e perda da liderança universitária}

A base institucional universitária de formação de pessoal na sub-região segue sendo principalmente pública, apesar do significativo incremento do setor privado nos últimos anos (ver Tabela 1), especialmente na Argentina e Brasil e no que se refere à Medicina e Enfermagem.

É necessário apontar que as escolas privadas são menores e com número pequeno de alunos em relação às públicas e que se localizam em áreas de maior desenvolvimento socioeconômico, como o sudeste brasileiro e a área de Buenos Aires, na Argentina.

\section{TABELA 1}

Instituições de Formação de Profissionais de Saúde Medicina, Odontologia e Enfermagem,

Países do Mercosul, 1993

\begin{tabular}{|c|c|c|c|c|c|c|c|c|c|c|c|}
\hline \multirow[t]{2}{*}{ Carreiras } & \multicolumn{2}{|l|}{ Argentina } & \multicolumn{3}{|c|}{ Brasil } & \multicolumn{3}{|c|}{ Paraguai } & \multicolumn{3}{|c|}{ Uruguai } \\
\hline & Tot Pub & Pri & Tot & Pub & Pri & Tot & Pub & Pri & Tot & Pub & Pri \\
\hline Medicina & 137 & 6 & 80 & 45 & 35 & 2 & 1 & 1 & 1 & 1 & - \\
\hline Odontologia & 108 & 2 & 81 & 46 & 46 & 35 & 2 & 1 & 1 & 1 & - \\
\hline Enfermagem & $95 \quad 64$ & 31 & 102 & 57 & 45 & 1 & 1 & - & 1 & 1 & - \\
\hline
\end{tabular}

Fonte: HRD, Sistema de Informação em Recursos Humanos em Saúde.

As escolas universitárias públicas da sub-região debatem-se com sérios problemas orçamentários (que não só se referem à diminuição das evasões, senão à estrutura das despesas que se destinam quase que exclusivamente ao pagamento de salários) e institucionais, tais como superpopulação estudantil e aumento da precariedade das relações do pessoal docente com a instituição, conseqüência dos baixos salários e da deterioração da infra-estrutura existente. 
As universidades públicas têm sustentado um mercado de trabalho docente que se expandiu de forma significativa nos últimos trinta anos nos países da sub-região, tanto no Brasil, que experimentou um crescimento sustentado de escolas, como nos outros países, que não sofreram esse fenômeno. Porém, nos últimos anos esse mercado tendeu à precariedade da inserção institucional. Um dado comum aos quatro países é a diminuição dos cargos docentes de dedicação exclusiva, o incremento da carga horária e a marcada diminuição dos salários docentes.

Essas tendências são preocupantes, já que afetam as funções básicas da instituição, como a docência e a pesquisa. É um fato patente na sub-região que as faculdades e escolas têm perdido protagonismo e liderança na definição dos critérios sociais dominantes de qualidade da Medicina.

\section{A formação de médicos}

Em quase todos os países se observou um incremento constante da matrícula de profissionais de saúde e, em especial, de médicos, até a primeira metade dos anos oitenta. A partir dessa data observa-se uma perda de qualidade da formação, especialmente na Argentina e no Uruguai, que têm matrícula livre.

O exame da disponibilidade de instituições de formação de médicos na sub-região mostra um desequilíbrio ou polaridade entre o Brasil (80 escolas ou faculdades), por um lado, e o Uruguai ( 1 faculdade) e o Paraguai (2 escolas). Além das simples diferenças quantitativas, que podem ser decorrentes de um problema de demanda em relação às diferentes populações, chama a atenção o grau de dispersão e fragmentação da oferta no Brasil, em relação à concentração da mesma nos demais países.

A Argentina se encontraria num lugar intermediário, com 13 faculdades, com a peculiaridade da criação de quatro escolas privadas durante os últimos dois anos. Chama a atenção que estes três últimos países não tenham incrementado o número de escolas (embora tenham aumentado suas matrículas) durante os anos de expansão na região.

Em geral, as faculdades ou escolas privadas de Medicina são "pequenas", com uma média de 50 a 60 alunos por turma, enquanto as públicas, ao contrário, têm um número bem mais elevado de alunos. Entretanto, estas diferenças de "tamanho institucional", de um modo geral com algumas exceções, compartilham critérios similares de orientação e estrutura curricular, determinadas pelo modelo hegemônico da prática médica.

A análise da informação disponível dos egressos das faculdades, o número de médicos em atividade nos países e a taxa resultante de reposição (quer dizer, a relação entre egressos e médicos ativos) demonstra que haveria um crescimento da população de médicos no Uruguai e no Paraguai (porém com menor intensidade), enquanto o Brasil e a Argentina estariam estáveis. 
Esta informação é apresentada na Tabela 2.

As opiniões dos setores dirigentes das escolas $\mathrm{e}$ faculdades universitárias (em especial do setor público) apontam para a existência de um quadro geral de deterioração na "competência tecnológica" e científica das mesmas. Os hospitais universitários em geral não conseguem manter a tecnologia atualizada, nem o "prestígio" de seus professores, que optam progressiva e majoritariamente pela alternativa de tempo parcial, por não terem remunerações adequadas, nem financiamento para suas pesquisas.

\section{A formação em Odontologia}

$\mathrm{Na}$ formação em Odontologia ocorrem algumas coincidências com as demais carreiras, como por exemplo o incremento significativo do número de instituições formadoras, que no Brasil atinge hoje 81 Escolas.

Tal expansão deveu-se basicamente à iniciativa privada, responsável pela abertura de 33 novas Escolas nos últimos 20 anos. A Argentina continua com as dez instituições que possuía, das quais oito são públicas e duas privadas. O Uruguai conta com uma Escola e o Paraguai com duas instituições, com o fenômeno singular que foi a abertura de uma nova Escola pelo Círculo Paraguaio de Dentistas (entidade corporativa).

\section{TABELA 2}

Recursos Humanos em Saúde no Mercosul

\begin{tabular}{lrrrr}
\hline País & Argentina & Brasil & Paraguai & Uruguai \\
\hline População 1992 (mil) & 34,154 & 156,672 & 4,124 & 3,158 \\
N Médicos & 88,800 & 208,966 & 3,161 & 9,789 \\
Med/10.000 hab & 26.0 & 13.3 & 7.7 & 31.0 \\
Grad. Med. circa 1990 & 3,000 & 7,100 & 150 & 500 \\
Reposição (\%) & 3.4 & 3.4 & 4.7 & 5.1 \\
& & & & \\
$N^{*}$ Enfermeiros NS & 22,000 & 57,047 & $1,375^{*}$ & $2,319^{*}$ \\
Enf/10.000 hab & 2.5 & 2.7 & 4.3 & 2.4 \\
Grad.Enf./Part. 1990 & 251 & 3,320 & $59^{*}$ & 101 \\
Reposição (\%) & 1.1 & 5.8 & 4.3 & 4.4 \\
& & & & \\
N Odontólogos & 21,900 & 118,609 & 1,160 & 3,512 \\
Odont/10,000 hab & 2.5 & 5.7 & 3.7 & 3.6 \\
Gra. Odont. circa 1990 & 973 & 5,945 & 31 & 135 \\
Reposição (\%) & 4.4 & 5.0 & 2.7 & 3.8 \\
\hline
\end{tabular}

* Inclui Obstetras.

Fonte: HRD, Sistema de Informação em Recursos Humanos em Saúde. 
Tal expansão deveu-se basicamente à iniciativa privada, responsável pela abertura de 33 novas Escolas nos últimos 20 anos. A Argentina continua com as dez instituições que possuía, das quais oito são públicas e duas privadas. O Uruguai conta com uma Escola e o Paraguai com duas instituições, com o fenômeno singular que foi a abertura de uma nova Escola pelo Círculo Paraguaio de Dentistas (entidade corporativa).

Uma característica comum ao Uruguai e Paraguai é a forte evasão de alunos antes da graduação: no primeiro, a perda chega a $2 / 3$ dos matriculados nos quatro anos antes da graduação, enquanto o Paraguai perde nada menos que $4 / 5$ dos alunos. Os altos custos da formação (sobretudo no que se refere a materiais e equipamentos), que são de responsabilidade do próprio estudante, é uma das explicações possíveis para a evasão.

Um problema que deverá ser objeto de cuidadoso estudo e que deriva do tipo de prática odontológica é a formação dos níveis auxiliares na estrutura ocupacional. Há classificações diversas de técnicos em higiene dental, higienistas dentais, assistentes dentais etc., quase todos formados no nivel secundário, sem uma diferença precisa entre tais perfis.

\section{A formação em Enfermagem}

A Enfermagem é uma categoria profissional crítica nos quatro países da sub-região. $O$ crítico de tal situação se refere tanto a elementos quantitativos (em geral uma situação deficitária ou com tendência decrescente no que se refere a disponibilidade de pessoal), como a elementos qualitativos referidos à natureza subordinada e desvalorizada de sua prática, à procura de uma redefinição de seu objeto de trabalho ou a deficientes condições de trabalho, entre outras características.

Esta categoria profissional é uma das mais complexas na definição dos níveis que conformam a sua estrutura como ocupação. Seus componentes variam de um país para outro, assim como os conteúdos dos seus objetos de trabalho, que variam inclusive no interior de um mesmo país e entre as diversas modalidades de organização da atenção à saúde. Da mesma maneira, os processos históricos de profissionalização são diferentes entre os diversos países, em alguns dos quais tem alcançado um significativo grau de autonomia e valorização social, ao passo que em outros persistem elementos de semiprofissionalismo e escasso status técnico e reconhecimento econômico e social.

Este desenvolvimento desigual se reflete na formação de enfermeiras nos países da sub-região. O quadro seguinte demonstra a diversidade de modalidades e niveis de formação existentes, relacionados com as formas de práticas existentes. 


\section{TABELA 3}

A Profissão de Enfermagem Segundo Níveis de Formação Países do Mercosul, 1993

\begin{tabular}{|c|c|c|c|c|}
\hline Niveis & Argentina & Brasil & Paraguai & Uruguai \\
\hline Superior & Licenciados & Enfermeiros & Licenciados & $\begin{array}{l}\text { Enfermeiros } \\
\text { profissionais/ } \\
\text { Licenciados }\end{array}$ \\
\hline Terciário & $\begin{array}{l}\text { Enfermeiros } \\
\text { profissionais }\end{array}$ & & & \\
\hline $\begin{array}{l}\text { Secundário } \\
\text { Primário } \\
\text { Elementar }\end{array}$ & $\begin{array}{l}\text { Auxiliar } \\
\text { Empírico }\end{array}$ & $\begin{array}{l}\text { Técnico } \\
\text { Atendente }\end{array}$ & Auxiliar & Auxiliar \\
\hline
\end{tabular}

Fonte: HRD, Sistema de Informação em Recursos Humanos em Saúde.

Esta diversidade de níveis, requisitos, currículos e perfis ocupacionais, tem uma representação no grau de dispersão das instituições formadoras, que nos quatro países se encontram em universidades, Ministérios de Saúde e de Educação e no setor privado, tanto de saúde, como de educação.

$\mathrm{Na}$ Argentina, país que tem uma das menores proporções de enfermeiras por população e uma estrutura de pessoal basicamente desqualificada, existem 95 instituições formadoras de pessoal de enfermagem, das quais 21 são de nível universitário, 45 de nível terciário não universitário (dependentes de educação e saúde) e 29 terciárias dependentes de educação.

No Brasil, existem atualmente 102 programas universitários de Enfermagem, dos quais $44 \%$ são privados. No Uruguai, existe uma escola universitária que forma enfermeiras profissionais de nível terciário e que oferece a opção adicional de uma licenciatura, um curso "profissionalizante" para auxiliares dependente do Ministério de Saúde Pública e diversos cursos para formar auxiliares em serviço. No Paraguai existe uma escola universitária.

Outra situação crítica nos países é o baixo número de ingressantes, assim como de egressos, o que estaria colocando em evidência não somente sérios problemas nos processos educativos no interior das instituições (são conhecidas as dificuldades que acontecem no currículo, na estrutura docente e na qualidade de ensino), senão também o baixo status social e técnico da profissão na sub-região. A situação de elevada evasão estudantil (que em média é de $60 \%$ para a Argentina e o Brasil) obrigaria a pensar em promover processos integrais de transformação educacional na perspectiva da integração e que antevejam novos perfis derivados da transformação tecnológica e das tendências da assistência à saúde.

É sabido internacionalmente que o pessoal de Enfermagem é um dos que mais migram de país em país, o que na situação genérica de relativa desqualificação de mão de obra existente nesta categoria e a diversidade na for- 
mação, poderia configurar uma difícil situação sub-regional e agravar déficits existentes. Isto deve ser considerado pelas lideranças políticas e profissionais, levando os países a colaborarem na busca de um mecanismo de meIhoramento da formação para a solução de problemas que de diversas formas são compartilhados.

\section{A pós-graduação médica}

A respeito dos estudos de pós-graduação, a situação é mais complexa do que nos estudos de graduação, devido à heterogeneidade do papel dos Estados na regulamentação destas atividades. Outra explicação importante para tal complexidade é que os estudos de pós-graduação vinculam-se direta e intimamente à fronteira do avanço do conhecimento e à incorporação tecnológica ao setor saúde, de um lado; e às exigências da competitividade dos mercados de trabalho na atual ordem econômica de organização da prática médica, do outro.

A regulamentação dos processos de preparação de especialistas, ao contrário daqueles de graduação, tem que enfrentar uma ampla gama de cenários e instituições, desde as formais até as informais, com maior dificuldade em países como a Argentina, onde a Universidade não tem tido liderança nesta área de formação.

Na sub-região, no que se refere à Medicina, há mecanismos distintos de preparação de especialistas: residências médicas, cursos de especialização, rotação por serviços de diversos graus de formalidade, mestrados e doutorados, cada uma delas procurando critérios para a sua regulamentação. Há, ainda, as heterogeneidades entre os países na interpretação das diferentes modalidades de estudos.

$\mathrm{Na}$ Argentina, as residências médicas são organizadas não somente pelas faculdades, mas também pelos serviços de saúde (hospitais) que, ao mesmo tempo, estão vinculados aos Ministérios ou Secretarias de Saúde estaduais, às Prefeituras, a obras sociais específicas, assim como ao setor privado. Cada uma destas instituições estabelece um regulamento próprio para suas residências (exceto em alguns Estados onde a habilitação de residências está concentrada em entidades deontológicas criadas por lei). Os mestrados e doutorados são muito pouco desenvolvidos na área profissional da Medicina. Os estágios e as especializações estão ainda menos regulamentados que as modalidades anteriores.

De maneira diferente, existe no Brasil uma rígida regulamentação das residências médicas pela Comissão Nacional de Residência Médica, do Ministério da Educação. Há regulamentos a respeito da composição e estrutura de treinamento em termos de carga horária, exigências de instalações, como bibliotecas e necrópsias sistemáticas nas instituições. 
Estabelece-se a remuneração dos residentes e se reconhecem 42 especialidades médicas. Porém, há uma forte concentração nas residências nas áreas básicas da medicina e em anestesiologia.

O processo da luta política que empreenderam os médicos residentes por melhores condições de aprendizagem e remuneração diminuíram drasticamente a oferta de vagas, que hoje se concentra quase que exclusivamente nos hospitais públicos, especialmente os universitários, que atendem menos de $1 / 3$ dos egressos dos cursos médicos.

As instituições assistenciais privadas oferecem modalidades de "treinamento em serviço" ou outras modalidades de capacitação que escapam das normas estabelecidas e, portanto, não têm o poder de titular os egressos. Os cursos de pós-graduação sensu strictu têm como principal objetivo a preparação de docentes e pesquisadores e não são muito freqüentes como mecanismo primário de formação de especialistas para a área profissional da Medicina.

No Paraguai há um projeto de regulamentação do exercício profissional especializado, que se encontra atualmente tramitando no poder legislativo. Enquanto isso, os egressos dos cursos médicos são preparados algumas vezes nos serviços de saúde existentes no país e, mais raramente, em serviços de referência sub-regional, nos países vizinhos ou nos centros mais desenvolvidos do mundo.

No Uruguai, o Ministério de Saúde oferece um número fixo de 100 vagas de residência, que são preenchidas por concurso nacional. A universidade também participa do financiamento destas vagas. Existem também cursos de especialização, fornecidos pelas cátedras e departamentos da Faculdade de Medicina, que concede títulos de especialização em diferentes áreas. Também no Uruguai há uma significativa procura pela continuidade dos estudos nos centros tecnologicamente mais desenvolvidos.

\section{LICENCIAMENTO E CONTROLE DO EXERCÍCIO PROFISSIONAL}

A existência de organismos de controle deontológico e de regulamentação autônoma da prática é uma das características do processo de "profissionalização" das ocupações. É habitual que existam naquelas profissões completamente estabelecidas e se gerem nas organizações corporativas, como uma forma de defesa contra o charlatanismo.

É desnecessário mencionar que esta defesa também inclui os estrangeiros, sobre os quais pesa, para esses organismos, um "pecado original", para cuja redenção deverão demonstrar inocência depois de um período de atuação condicional.

Os estrangeiros que procedem de países onde existam convênios oficiais são admitidos no exercício profissional sem maiores dificuldades, salvo um trâmite formal. Os que realizaram estudos em outros países devem sub- 
meter seus planos de estudo a consideração de uma universidade, onde são comparados com os nacionais e revalidados, com exigências que podem variar de caso a caso.

Naquelas situações em que o organismo de controle deontológico está vinculado ao Estado, como no Uruguai, estes mecanismos podem ser modificados por acordos diplomáticos, mas seguramente existirão resistências à aceitação do profissional forâneo em condições similares ao nacional. Na Argentina e no Brasil estes mecanismos, do tipo corporativo, porém de caráter legal, são de responsabilidade estadual, pelo que podem se incluir nas áreas de interesse das jurisdições das áreas de fronteira no processo de integração. No Paraguai e no Uruguai existem projetos em nível legislativo que tocam estes aspectos, que poderiam vir a integrar uma agenda de discussão que envolvesse parlamentares e organismos corporativos dos diferentes países.

Uma condição comum a todos os países é que não existe requisito adicional à apresentação do diploma para a habilitação do exercício profissional, tais como exames de capacidade feitos pelo Estado ou pela corporação ou, mesmo, a obrigatoriedade do serviço social, como ocorre na área andina (Bolívia e Peru). O licenciamento é definitivo, não havendo exigências de recertificação para a formação básica, existindo atualmente alguns projetos de recertificação apenas com relação às especialidades.

$\mathrm{Na}$ Argentina, as Escolas titulam e aqueles egressados na Capital Federal devem registrar seus diplomas na Secretaria de Saúde da Nação, o que os habilita para o exercício profissional. Nos Estados, o registro acontece nas Secretarias (Estaduais) de Saúde ou nos Colégios Médicos por delegação das primeiras. Em relação às especialidades médicas, há três instâncias que habilitam para seu exercício, que são as universidades, as associações e colégios profissionais e determinados serviços creditados para tal finalidade. Estão atualmente reconhecidas pela Direção Nacional de Regulação e Controle do Exercício Profissional e de Especialidades Médicas da Secretaria de Saúde da Argentina 63 especialidades médicas e 7 pediátricas, o que soma um total de 70 especialidades. Existe um projeto de recertificação do exercício de especialidades a cada cinco anos, ainda não regulamentado nacionalmente. Em Córdoba, a recertificação de especialidades existe há trinta anos, com exames rigorosos e bancas pagas pela instituição deontológica. $O$ controle ético do exercício profissional está em princípio a cargo dos conselhos profissionais.

No Brasil, as Escolas, sejam públicas ou privadas, emitem os diplomas que devem ser registrados nos Conselhos Regionais da respectiva profissão, autarquias públicas responsáveis pelo controle ético do exercício profissional. Não há necessidade de revalidar o título durante toda a vida profissional. No caso da Medicina e da Odontologia, as especialidades devem ser igualmente registradas nos Conselhos e são obtidas através da realização de residências ou cursos de pós-graduação sensu strictu ou de outras modalidades. 
Em Medicina se reconhece agora um leque de 54 especialidades e, em Odontologia, 14.

Paulatinamente, tende-se a exigir nos concursos públicos os registros de especialistas pelos Conselhos, o que tem levado à valorização dos mecanismos formais de especialização. Outra forma de obtenção do registro de especialista é a comprovação do exercício profissional por um tempo determinado, o que não passa de um mecanismo marginal em relação às demais modalidades.

No Uruguai, o título obtido no país ou o título do exterior revalidado deve ser registrado em divisão de coordenação e controle do Ministério de Saúde, que habilita para o exercício em todo o país. Adicionalmente, os profissionais que desejem realizar o exercício profissional devem se registrar na Caixa de Aposentadorias e Pensões de profissionais universitários.

Existe uma lei de especialidades médicas que regula seu exercício, reconhecida pelas Escolas de Graduação, que estabelece como obrigatório o registro como especialista para o exercício legal de funções públicas ou privadas. Desta maneira, o exercício das especialidades é regulamentado e pode ser sancionado da mesma forma que o exercício da Medicina. A função do controle ético é exercida pela Comissão Honorária de Saúde Pública, do Ministério de Saúde, que funciona desde 1934.

No Paraguai existe o Departamento de Controle Profissional do Ministério da Saúde, que registra e habilita para o exercício profissional, desde que cumpridas determinadas exigências formais, como a apresentação do diploma e pagamento de taxas. Este Departamento controla também os aspectos éticos da prática profissional pela aplicação do Código Sanitário. Para os profissionais formados no exterior se exige a revalidação de diploma pela Universidade de Assunção. As especialidades continuam aguardando a sanção de uma lei pelo Congresso, ainda não aprovada, que estabelece a associação compulsória dos profissionais.

\section{MERCADOS DE TRABALHO E EMPREGO}

Um dos impactos mais diretos do MERCOSUL nos recursos humanos há de se traduzir na livre circulação de mão-de-obra entre os países signatários. Tratando-se de mão-de-obra com uma qualificação muito particular, sua circulação pode produzir modificações em diversos campos, desde mudanças na equação econômica dos serviços de saúde, até a introdução de novas práticas assistenciais nas regiões em que não existia um desenvolvimento prévio.

Esta circulação deveria, de acordo com as leis do mercado, contribuir para a reparação dos desequilíbrios de oferta e demanda de mão-de-obra, permitindo a solução de excessos ou defeitos e regulando o custo do insumo humano na equação da produção de serviços. Entretanto, é conhecida a insuficiência das leis de mercado para explicar as variações de oferta, de- 
manda e preço do pessoal em saúde. A baixa elasticidade dos mecanismos de formação, o papel social das profissões da saúde, as vinculações entre algumas profissões e os papéis masculino e feminino, os mecanismos corporativos, entre outros fatores, explicam a formação de significativos desequilibrios entre a disponibilidade e a utilização de pessoal.

Estes desequilíbrios têm em geral um caráter sub-regional, coexistindo em cada país zonas de oferta excessiva com zonas de déficit. Isto não permite antecipar que a livre circulação de pessoal através das fronteiras nacionais venha a contribuir de forma substantiva para solucionar os desequilíbrios existentes, e nem sequer poderia se afirmar que os mesmos não irão se agravar. Provavelmente, o Tratado de Assunção permitirá uma maior liberdade de escolha para os profissionais, que poderão eleger o âmbito de ação, sem passar pelos atuais fenômenos de exílio, além de oferecer novas opções de solução a situações transitórias de escassez.

Os diagnósticos de excesso de médicos nas áreas metropolitanas, de falta de enfermagem profissional em nivel do país, de desigualdades urbanorural de distribuição de profissões são comuns aos quatro países. Seria recomendável realizar um estudo comparativo sobre os mercados de trabalho de médicos, de enfermagem e de odontólogos nas diferentes zonas que compõem a área a integrar, procurando estruturar um sistema de monitorização de variáveis de oferta, demanda e desempenho profissional.

As diferentes modalidades de emprego profissional tem especial transcendência na configuração deste mercado ampliado de trabalho. Existem inúmeras variáveis, desde a prática profissional liberal até o assalariamento, passando por sistemas mistos ou de repartição de riscos, tais como a capacitação ou a associação dos prestadores em cooperativas. Um estudo detalhado das diferentes opções de emprego pode servir como apoio para o desenvolvimento de novos esquemas de organização do trabalho e comparar as vantagens de cada um. Pode, ademais, flexibibilizar as relações entre empregadores e empregados ao introduzir no menu de negociação formas bem-sucedidas em outras realidades, que possam ser avaliadas e adaptadas.

\section{O mercado de trabalho médico}

Como pode ser visto na Tabela 2, a disponibilidade de médicos observada através da relação médicos/10.000 hab. é muito diferenciada entre os países, onde o Uruguai (31.0) e a Argentina (26.0) se encontram em vantagem ante o Paraguai (7.7), enquanto o Brasil se localiza em posição intermediária (13.3).

Esta situação expressa também a grande diferença entre as formas de organização dos sistemas de saúde e a sua cobertura (extensão e eqüidade). É previsível que no Paraguai subsistam ainda sem cobertura determinadas patologias ou atendimentos de "alta complexidade". 
O processo de feminização é semelhante em todos os países, uma média de $30 \%$. No Uruguai as mulheres representam agora $40,2 \%$ da força de trabalho médico.

Nos quatro países há uma concentração geográfica de profissionais médicos nas capitais ou em áreas de maior desenvolvimento socioeconômico (regiões metropolitanas): a Capital Federal e a Grande Buenos Aires concentram 54\% dos médicos argentinos; ao mesmo tempo, Montevidéu e Assunção têm de 80 a $82 \%$ da totalidade dos médicos de seus respectivos países. A região Sudeste (estados de São Paulo, Rio de Janeiro e Minas Gerais) são responsáveis pela localização de $61 \%$ dos médicos e, se anexarmos a região Sul, a concentração alcança $74 \%$.

Em todos os países ocorre uma tendência ao assalariamento, onde se destacam o Brasil (com 61\%) e o Uruguai (com 74\%). A prática privada não chega a estar em vias de desaparecimento, porém perde espaço no mercado de trabalho.

Estudos recentes mostram uma taxa de desemprego de $7 \%$ no Uruguai. Na Argentina é de $9,1 \%$ (para a região de Rosário) no primeiro ano e $5,2 \%$ no segundo ano após a graduação. No Uruguai, um estudo recente sobre o subemprego dos médicos mostrou taxas de 14 a $28 \%$ nas diversas áreas do país.

O multiemprego é uma tendência geral, com médias de 1,8 empregos por médico para o Brasil e de 2,6 para o Uruguai. Isto reflete um esforço de superação dos baixos salários.

No Brasil, informações recentes mostram uma grande variação dos níveis salariais, que são de 60 a 200 USD, aproximadamente, nas Secretarias de Saúde estaduais (poucas têm salários acima de 200 USD), enquanto os salários do INAMPS/Ministério de Saúde situam-se entre 500 a 750 uSD.

Há uma tendência aparentemente irreversível para a especialização: o Brasil tem $57 \%$ de médicos especialistas, a Argentina $69 \%$ e o Uruguai $90 \%$. No Paraguai ainda não existe um sistema de registro dos especialistas.

O emprego no setor público é majoritário no Brasil (55\%) e representa $1 / 3$ das vagas de trabalho no Uruguai e no Paraguai.

\section{O mercado de trabalho dos odontólogos}

A disponibilidade da força de trabalho odontológica é mais homogênea nos quatro países da sub-região, como pode se observar na Tabela 2. Entretanto, existem denominadores comuns, tais como: a tendência para a composição feminina da profissão, a concentração nas capitais e grandes centros urbanos dos países (sendo interessante que no caso paraguaio a distribuição dos técnicos dentais se localiza na sua maioria no interior do país) e a modalidade dominante de prática privada liberal. 
Esta modalidade de prática dominante é significativa nos quatro países, chegando a $54 \%$ o trabalho exclusivo no âmbito privado liberal na Argentina e no Brasil. Este é um dado a considerar em uma linha de trabalho orientada pela eqüidade e a universalização da cobertura para a população, considerando a escassa ênfase atribuída à saúde oral pelas políticas de saúde dos diversos governos.

\section{O mercado de trabalho do pessoal de Enfermagem}

Tem sido apontada a diversidade e complexidade da estrutura da força de trabalho de Enfermagem nos países da sub-região, o que se complica pela existência (ou não) de profissionais da área de obstetrícia diferenciados dos de enfermagem em determinados períodos históricos. Esta diversidade qualitativa tem o seu correlato na disponibilidade deste pessoal, como pode ser apreciado na Tabela 1.

Em geral, estes dados expressam déficits para o conjunto dos países, grave no que se refere ao pessoal de qualificação superior, o que caracteriza uma estrutura básica desqualificada. Esta estrutura reflete a escassa hierarquia técnica e a baixa valorização social que recebe a profissão.

O déficit quantitativo é particularmente preocupante no caso da Argentina: a informação censitária disponível revela a diminuição de $40 \%$ e pesquisas mais dirigidas apontam uma importante imigração para o exterior do pessoal mais qualificado.

Na sub-região, como em todas partes, a enfermagem é uma profissão feminina na sua maioria (entre $83 \%$ de mulheres na Argentina e quase $95 \%$ no Brasil) que, como a maioria das categorias profissionais, tende a se concentrar nas grandes cidades.

É uma prática exclusivamente dependente e assalariada, que atualmente tem níveis de multiemprego e subemprego variáveis porém significativos e com difíceis condições de trabalho nos quatro países.

Sem dúvida, esta categoria profissional merece uma atenção especial e políticas integrais de desenvolvimento quantitativo e qualitativo urgentes, tanto nos processo de formação como nos serviços e condições da sua prática, sem o que o processo de integração poderá agravar os desequilíbrios e deficiências já existentes.

\section{O mercado de outras profissões}

Nos estudos realizados não foi possível verificar a situação das demais profissões da saúde. É conhecido que algumas delas têm importância especial em um contexto de um mercado comum, como é o caso da medicina veterinária, a nutrição, a farmácia-bioquímica e a engenharia sanitária. Em alguns casos, as preocupações atuais com o problema de alimentos e a epidemia do cólera põem em especial destaque estas profissões. Por isto, seria for- 
temente recomendável que essas e as demais profissões de saúde fossem igualmente estudadas para futuras ocasiões.

\section{REPRESENTAÇÃO CORPORATIVA}

Não menos transcendente que os temas revisados antes é a ação da representação social de cada profissão. Dela deriva o peso específico que tem na sociedade e, portanto, nas decisões do governo que as afeta, mas também influirá na orientação de seus organismos de classe e, subseqüentemente, no seu poder de pressão.

Talvez, numa primeira etapa, os organismos de representação sejam os principais interessados nos processos de integração de mercados de trabaIho e no licenciamento e controle profissional. De fato, até o momento tanto - Círculo Paraguaio de Médicos, o Sindicato Médico do Uruguai e Sindicatos e Associações argentinas e brasileiras têm realizado contatos com seus pares a fim de melhorar sua visão do panorama futuro. Se bem que exista uma tendência defensiva natural nessas organizações, elas não podem evitar que seus membros se sintam incentivados pelas oportunidades que um mercado de trabalho ampliado oferece e, de qualquer maneira, lutarão para que as aberturas sejam recíprocas.

Um aspecto particular está constituído pelo impacto que terá a integração nos mecanismos habituais de conflito e negociação. Em outras áreas econômicas, a integração empresarial impele a integração sindical, que pode ser facilitada pelos organismos de coordenação nacional de trabalhadores. No caso dos países grandes terão também transcendência as agrupações regionais limítrofes.

Nos casos em que existe um sistema de regulamentação oficial do mercado de trabalho em saúde, como no Uruguai, o impacto de novas realidades deverá ser considerado, levando em conta também que existem esforços oficiais de desregulamentação do mercado de trabalho. 


\section{Argentina: SITUAÇÃO DOS RECURSOS HUMANOS EM SAÚDE}

Mónica C. Abramzón

\section{INTRODUÇÃo}

A Argentina - como todos os países da América Latina - enfrenta, desde o início da década de 90 , uma persistente recessão econômica que vem determinando mudanças cada vez mais profundas na sua estrutura social ${ }^{1}$.

A tentativa de superar a crise da década de 80 foi baseada na aplicação de severas políticas de ajuste que afetaram as condições de vida de amplos setores da população, aumentando ainda mais os níveis de emprego precário e desemprego, provocando uma queda geral no nível de renda e, por conseqüência, o crescimento dos índices de pobreza ${ }^{2}$.

Em função disso, é válido esperar, a médio prazo, modificações nas condições de saúde da população, que podem ser dimensionadas a partir da

1 A título de exemplo, mencionamos os seguintes dados, referentes à Argentina: o PIB por habitante caiu 23,5\% entre 1981 e 1989; o desemprego urbano aberto passou de 2,6 a 6,5 de taxa média anual entre 1980 e 1988 (CEPAL: Transformación Productiva con Equidade, Chile, 1990).

2 Segundo os dados da Encuesta Permanente de Hogares do INDEC para 1988, a evolução da pobreza na Grande Buenos Aires registra um crescimento de $73 \%$ sobre 1980 . 
tendência, que já se faz sentir, do ressurgimento de perfis e causas de mortalidade e morbidade que historicamente supunha-se já terem sido eliminados.

Uma das repercussões da implementação das políticas de ajuste que mais depressa aparece ocorre no mercado de trabalho.

Essas políticas afetaram também o setor saúde, reforçando a tradicional falta de coordenação intra- e intersetorial, deteriorando ainda mais os serviços e a qualidade de sua prestação, resultando daí uma grande ineficiência das ações.

Em termos administrativos, grande parte dos recursos públicos existentes está sob jurisdição provincial ${ }^{3}$ e de alguns municípios maiores. Em nível nacional, sua gestão está sob a responsabilidade do Ministério da Saúde e Ação Social, que, através da Secretaria de Saúde, exerce certas funções de regulação e coordenação com as províncias. $O$ cerne das decisões referentes ao sistema de saúde passa pelo manejo dos recursos financeiros, onde se destaca o papel do Sistema Unico de Seguridad Social (suss) como órgão de coordenação e redistribuição da seguridade social 4 .

A partir da recente desregulamentação da afiliação às "obras sociais" e dos mecanismos de contratação, o modelo anterior de três subsetores bem diferenciados está mudando vertiginosamente, verificando-se uma profunda reformulação na relação do Estado com a sociedade, devido ao crescente afastamento do setor público da sustentação do setor saúde. As obras sociais visam a eficiência e a produtividade, os hospitais públicos desenvolvem uma "privatização periférica" e diversas modalidades de subemprego alcançam legitimação.

Nesse contexto, as práticas em saúde que historicamente se caracterizaram por um importante excesso de procedimentos cirúrgicos e laboratoriais, bem como técnicas complexas de diagnóstico, incentivam a utilização de tecnologias sem uma avaliação adequada de sua pertinência.

Em estreita vinculação com as modificações ocorridas nos serviços de saúde, registram-se mudanças importantes no mercado de trabalho. Em termos gerais, observa-se em todas as categorias uma forte tendência à especialização, coincidindo com a incorporação tecnológica.

Ao mesmo tempo, a diminuição generalizada da remuneração determina menor qualificação e menor dedicação no resto das categorias ocupacionais, porquanto o profissional precisa procurar outras alternativas para assegurar sua renda.

3 "provincial" = "estadual": uma Província na República Argentina equivale a um Estado no Brasil. (N. da T.)

4 Esse sistema, atualmente dentro da órbita do Ministério do Trabalho, substitui, desde fins de 1991, a ANSAL (Administración Nacional de Seguro Social de Salud) criada em 1988, que por sua vez substituiu o INOS (Instituto Nacional de Obras Sociales), existente desde 1969. 
A combinação dessas situações gera ineficiência e baixa qualidade na prestação dos serviços, sobretudo no subsetor público e no subsetor das "obras sociais", que atendem principalmente aos grupos de menor renda.

Por outro lado, como observam Nogueira e Brito, a partir da década de 80 cresceu de maneira marcante a participação das mulheres no setor. Embora a proporção feminina há muito seja importante nos niveis menos hierarquizados (enfermagem, auxiliares), atualmente ela tem aumentado também nas categorias mais qualificadas ${ }^{5}$.

De modo geral, observa-se o incremento do trabalho assalariado e uma elevada proporção de empregos múltiplos e subempregos.

Em síntese, pode-se afirmar que não existe no país uma contextualização adequada da problemática no campo dos recursos humanos que, levando em conta a conflitividade do setor, possibilite uma ação planejada a serviço das necessidades sociais. Como conseqüência, o mercado é a única instância reguladora do que oferecem determinados atores com interesses específicos no setor - interesses que obviamente não coincidem com os interesses dos recursos humanos em saúde, nem com os da população por eles atendida.

\section{A FORÇA DE TRABALHO DO SETOR}

É preciso assinalar mais uma vez que não é possível estabelecer com precisão a dimensão real da força de trabalho do setor, seja de forma global, seja para cada uma das diferentes categorias profissionais que a compõem.

Como já é sabido, a última informação objetiva é de 1980 e corresponde ao Censo de Pessoal e ao Cadastro Nacional de Recursos e Serviços para a Saúde (CANARESSA). Ambos, por motivos distintos - o Censo, porque o mapeamento incluiu apenas pessoas que trabalhavam em instituições de serviços, e o Cadastro, porque registrou postos de trabalho, e não pessoas - não constituem uma base segura para que a partir deles seja calculada a atual dimensão do setor.

Por outro lado, nem o Censo Nacional da População de 1991, nem a Encuesta Permanente de Hogares (EPH) que o Instituto Nacional de Estadisticas y Censos (INDEC) realiza por amostragem nos conglomerados urbanos mais importantes, com periodicidade bianual, permitem obter dados referentes ao número de pessoas por categoria trabalhando no setor.

$\mathrm{Na}$ tabela da EPH correspondente ao mês de outubro de 1991, e apenas para a Grande Buenos Aires, foi introduzida uma nova codificação que permite saber o número de assalariados em estabelecimentos de saúde segundo a hierarquia ocupacional e o tamanho do estabelecimento.

5 Nogueira, R. Passos e Brito, P. L.: Recursos Humanos en Salud de las Americas. Educación Médica y Salud, Vol. 20, n². 3, OPS-OMS, 1986. 
Mesmo assim, a possibilidade de obter-se informação a partir do Censo Nacional de 1991 fica prejudicada porque, por motivos orçamentários, não foram feitas - embora tecnicamente fosse possível - as tabulações correspondentes aos dados básicos de cada ocupação. Desse modo, e em ocasião ainda não prevista, o Censo permitiria conhecer apenas o número de pessoas que prestam serviços no setor por grandes grupos (profissionais, técnicos, agentes, administradores) sem distinção de categoria.

Por outro lado, a informação produzida por diversas instituições do setor saúde e associações sindicais ou profissionais, embora seja em geral mais atualizada, tem o inconveniente de nem sempre utilizar categorias compatíveis, além da possibilidade de conter duplicações ou de ser incompleta. Trata-se, porém, da estimativa mais próxima possível da dimensão da força de trabalho no setor.

Hoje em dia é difícil conhecer com certeza a População Economicamente Ativa (PEA) global, já que os dados do Censo Nacional de População de 1991 ainda não foram totalmente processados. Segundo os dados parciais disponiveis e as estimativas do próprio INDEC, a PEA abrangeria 13 milhões de pessoas; dessas, cerca de 433.000 trabalhariam hoje em dia no setor saúde, isto é, 3,3\% da PEA global (Tabela 1). Esse dado indicaria um estancamento na participação relativa da PEA de saúde na PEA global em níveis históricos equivalentes aos de 1980 (2,9\%). Esta percentagem, por sua vez, representa um retrocesso em relação às estimativas realizadas em 1988 com base nas tendências verificadas desde 1984 no setor serviços da economia argentina ${ }^{6}$.

Segundo os dados disponíveis no momento, e sobre uma PEA total de 10 milhões de pessoas, foi calculado que o setor saúde ocupava cerca de 400.000 pessoas, isto é, $4 \%$ do total. Desse modo, o número de pessoas ocupadas no setor teria experimentado pequeno crescimento, ao passo que o correspondente à PEA total teria crescido em $20 \%$.

Sem dúvida, deve-se buscar a explicação para essa situação nas mudanças ocorridas no setor saúde, no que diz respeito tanto à configuração do sistema de atenção quanto às modalidades que os serviços assumem em cada um dos subsetores. Como conseqüência, foram modificados - embora seja difícil fazer uma avaliação - os processos de organização e gestão de trabalho, o tipo de prestação mais freqüente, a ênfase em determinadas práticas e as ações dirigidas à formação, captação e utilização dos recursos humanos.

Tudo isso no contexto de um significativo achatamento do setor público, de uma queda generalizada das remunerações e de uma duradoura tendência a dificuldades de emprego, que determinam que o setor não apenas deixe de ser um campo de trabalho atraente, mas também passe virtualmen- 
te a expulsar a força de trabalho, em particular nas categorias de menor nivel hierárquico. Segundo estimativas recentes da área de Enfermagem da División de Recursos Humanos da OPAS-Argentina, nos últimos três anos cerca de 2.000 enfermeiros haviam abandonado o país, atraídos pela oferta de melhores salários em outros países - entre eles, Estados Unidos, Espanha, Itália e Austrália.

\section{TABELA 1}

Estimativa da Força de Trabalho no Setor Saúde por Categoria - Argentina, 1992

\begin{tabular}{lr}
\hline Categoria & Número \\
\hline Médicos & 88.800 \\
Odontólogos & 21.900 \\
Farmacêuticos & 10.500 \\
Bioquímicos & 7.500 \\
Parteiros/Obstetras & 4.000 \\
Fisioterapeutas & 6.000 \\
Psicólogos & 32.000 \\
Enfermeiros & 18.000 \\
Aux. Enfermagem e empíricos & 51.000 \\
Técnicos & 90.000 \\
Administração e serviços gerais & 95.000 \\
Assistentes Sociais & 3.000 \\
Engenheiros Sanitários & 1.000 \\
Nutricionistas & 4.000 \\
\hline Total & 432.700 \\
\hline
\end{tabular}

Fonte: Estimativas do autor baseadas em dados fornecidos pelas instituições consignadas no ANEXO III.

Desse modo, a estrutura ocupacional do setor continua apresentando o formato de uma pirâmide invertida, na qual a participação relativa das categorias profissionais é muito superior à das categorias técnicas e auxiliares.

Finalmente, não se dispõe de informação suficiente para realizar uma caracterização completa da distribuição da força de trabalho do setor por sexo. Conta-se apenas com dados parciais, provenientes de alguns estudos sobre grupos profissionais específicos que, por seu caráter, não permitem extrair conclusões válidas para o conjunto.

Em linhas gerais, pode-se destacar uma tendência crescente à feminização das matrículas universitárias nas carreiras da saúde, particularmente em Medicina, Farmácia e Bioquímica, e Odontologia, mantendo-se - ou acentuando-se - a tradicional predominância de mulheres em outras, como Nutri- 
ção, Fonoaudiologia e Enfermagem. Os dados provenientes dos sucessivos Censos de Alunos realizados desde 1964 pela Universidade de Buenos Aires ilustram esta tendência (Tabela 2).

\section{Médicos}

Como já foi assinalado, não existem no país instrumentos confiáveis que informem o número exato de profissionais médicos em atividade. Como conseqüência, a estimativa deve basear-se num conjunto de fontes que, combinadas, dão consistência aos dados.

De acordo com a revisão de informação secundária, consulta efetuada a colegiados e associações sindicais e algumas projeções oficiais e particulares, pode-se calcular que, para 1992, o número de médicos em atividade estaria entre 88 e 90 mil.

\section{TABELA 2}

Evolução da Participação Feminina nas Matrículas de Faculdades da Universidade de Buenos Aires (em Percentagem)

\begin{tabular}{cccc}
\hline Ano & Medicina & Odontologia & Farmácia e Bioquímica \\
\hline 1964 & 32,4 & 49,2 & 55,6 \\
1968 & 37,3 & 54,2 & 55,1 \\
1971 & 39,1 & 56,5 & 62,0 \\
1972 & 41,5 & 58,7 & 66,1 \\
1980 & 54,5 & 68,4 & 72,4 \\
1988 & 61,4 & 61,7 & 68,2 \\
\hline
\end{tabular}

Fonte: Elaboração do autor, baseado em dados dos Censos de Alunos da Universidade de Buenos Aires.

Faz-se necessário explicar como se chegou a essa estimativa. Segundo tabelas inéditas 7 , o Censo Nacional de População de 1980 registrou 59.706 médicos; 14.300 trabalhavam no setor público e de ação social, e 45.406 no setor privado; destes últimos, 18.750 - 41,2\% - trabalhavam apenas por conta própria.

A esse total de médicos de 1980 foram acrescentados os diplomados anualmente pelo sistema universitário (Tabela 3). Por não estarem disponíveis os dados dos diplomados entre 1990 e 1992, estes foram estimados em 3.300 anuais. A essa soma aplicou-se a taxa média de mortalidade estimada para a faixa etária da categoria, calculada por sexo (14/10.000). Ao número resultante descontou-se uma taxa de aposentadoria ou migração equivalente

7 Tabelas inéditas do Censo Nacional de População de 1980, processadas por convênio com o Projeto PNUD-OIT - Ministerio de Trabajo, 1985. 
a $0,5 \%$ dos diplomados em cada ano. Desse modo foi estimado o número de médicos em atividade no país em 1992.

É conveniente expor pelo menos duas considerações que permitam avaliar essa estimativa:

1. Segundo Katz, Tafani e Muñoz ${ }^{8}$, até 1987 podia-se calcular uma proporção de 425 habitantes por médico, e, sabendo-se que o número de médicos cresceu historicamente a uma taxa anual superior à da população, podese supor que até 1992 essa razão perfaria 370 habitantes por médico. Já que a projeção da população para 1992 a partir do último censo nacional chegaria a 33.130.000 habitantes, o número de médicos alcançaria 89.542 .

2. A Confederación Médica de la República Argentina implementou um sistema de cobertura de saúde para profissionais médicos denominada "Rede Argentina de Saúde", que garante em todo o país o atendimento médico aos associados, independentemente do lugar de residência. Lançado há um ano, esse sistema de inscrição voluntária, através das associações regionais, já conta com 71.000 médicos associados. Levando-se em conta que a quantidade de alternativas equivalentes disponíveis hoje em dia no mercado aumenta em função do grau de desenvolvimento de cada núcleo populacional, é provável que o número de associados ao sistema tenha sido menor nos grandes centros urbanos. Por isso, esta cifra é um bom indicador do piso a partir do qual se pode estimar a quantidade de médicos.

Torna-se necessário expor, neste momento, algumas observações a respeito de estimativas anteriores.

A mais difundida entre elas foi a estimativa do Instituto di Tella ${ }^{9}$, baseada em informações elaboradas por organismos oficiais para $1985^{10}$.

$\mathrm{Em}$ ambos os documentos, estimou-se o número de médicos a partir de dados do CANARESSA, que registram 69.388 cargos médicos no país em 1980. Levando-se em conta que, segundo algumas análises baseadas em dados de recenseamento disponíveis, a relação média cargo/pessoa no setor alcançava, nessa época, 1,69, conclui-se que o número de médicos tomado como base constituía uma estimativa exagerada.

A comparação por subsetor dos dados que fundamentaram ambas as estimativas permite-nos estabelecer que já nesta data a taxa de dupla ocupação no setor público alcançava 1,33, ao passo que a taxa correspondente ao setor privado chegava a 2,37. Essa diferença se deve, por um lado, à tradicional limitação em termos de jornada de trabalho estabelecida para a administração pública, e, por outro, à maior variedade de alternativas oferecidas pe-

8 Katz J., Muñoz A., Tafani R.: Organización e Comportamiento de los Mercados Prestadores de Servicios de Salud: Reflexiones sobre el Caso Argentino.

9 Dieguez H., Llach J. (Coord.) e Petrecolla A.: El Gasto Público Social. Vol. IV: El Gasto Público em Salud. Instituto Torquato di Tella, Buenos Aires, 1990.

10 MSAS, OPAS/OMS, 1985. Argentina: Descripción de su Situación de Salud. 
las diversas formas de trabalho assalariado no setor privado. Devido às características das perguntas dos recenseamentos, na categoria "conta própria" incluíram-se aqueles profissionais que só trabalhavam assim, e que não tinham sido computados pelo CANARESSA.

TABELA 3

Médicos Diplomados por Universidade Argentina, 1980-1989

\begin{tabular}{lrrrrr}
\hline Universidade & 1980 & 1981 & 1982 & 1983 & 1984 \\
\hline Buenos Aires & 2.189 & 2.213 & 2.291 & 1.768 & 1.495 \\
Córdoba & 1.138 & 1.135 & 949 & 950 & 748 \\
Cuyo & 63 & 86 & 83 & 161 & 126 \\
La Plata & 940 & 794 & 799 & 900 & 809 \\
Nordeste & 212 & 199 & 215 & 231 & 292 \\
Rosário & 520 & 588 & 489 & 412 & 380 \\
Tucumán & 120 & 181 & 184 & 248 & 275 \\
del Salvador & 51 & 35 & 37 & 49 & 46 \\
Católica Córdoba & 40 & 60 & 63 & 68 & 77 \\
\hline Total & 5.273 & 5.291 & 5.110 & 4.747 & 4.248 \\
\hline Universidade & 1985 & 1986 & 1987 & 1988 & 1989 \\
Buenos Aires & 1.152 & 938 & 1.040 & 1.086 & 1.141 \\
Córdoba & 653 & 552 & 481 & 457 & $663^{\star}$ \\
Cuyo & 170 & 119 & 75 & 98 & 83 \\
La Plata & 746 & 658 & 536 & 356 & $410^{\star}$ \\
Nordeste & 297 & 164 & 184 & 144 & 153 \\
Rosário & 301 & 279 & 285 & 244 & 241 \\
Tucumán & 268 & 294 & 187 & 141 & $160^{\star}$ \\
del Salvador & 47 & 48 & 40 & 43 & 58 \\
Católica Córdoba & 75 & 71 & 38 & 41 & 45 \\
\hline Total & 3.619 & 3.123 & 2.866 & 2.610 & 2.954 \\
\hline Font Universidades & & & & & \\
\hline
\end{tabular}

Fonte: Universidades Nacionales: Dirección de Estatísticas, Ministerio de Cultura y Educación de la Nación; Católica de Córdoba: Situación Actual de 1* Educación Médica en la República Argentina. OMS/OPAS. $n^{*} 24.1989$.

* Estimativa.

Além disso, a distribuição geográfica dos médicos também é desigual, tanto regionalmente quanto, dentro de cada região, entre áreas urbanas e rurais.

Embora não se possa determinar com precisão, pelos motivos já expostos, o número de médicos por província, é possível fazer uma estimativa partindo dos dados correspondentes a 1980. 
Existem dois fatos que permitem supor que a distribuição de profissionais médicos por província não sofreu variações significativas. Em primeiro lugar, desde 1980 não se produziram mudanças na localização geográfica de novas Escolas de Medicina; em segundo lugar, nesse período não foram implementadas políticas orientadas para estimular ou promover a realocação de profissionais.

Em conseqüência, se distribuirmos o número estimado de médicos para $1992(88.800)$ com base na estrutura correspondente a 1980, e calcularmos daí sua relação para a população registrada pelo Censo Nacional de População de 1991, concluimos que para o total do país o número de habitantes por médico atinge 367 . Nos pontos extremos da relação encontramse a Capital Federal, com uma relação de 113 habitantes por médico, e Formosa, com 911 habitantes por profissional (Tabela 4).

TABELA 4

Estimativa da Distribuição de Médicos por Província Argentina, 1991-1992

\begin{tabular}{lrrr}
\hline Província & População 1991 & Médicos 1992 & Hab/Médicos \\
\hline Capital Federal & 2.960 .976 & 26.195 & 113 \\
Buenos Aires & 12.582 .321 & 21.934 & 574 \\
Catamarca & 265.571 & 532 & 49 \\
Córdoba & 2.764 .176 & 9.502 & 291 \\
Corrientes & 795.021 & 1.421 & 559 \\
Chaco & 838.303 & 1.332 & 629 \\
Chubut & 536.587 & 710 & 502 \\
Entre Rios & 1.022 .865 & 2.131 & 480 \\
Formosa & 404.367 & 444 & 911 \\
Jujuy & 513.992 & 1.066 & 482 \\
La Pampa & 260.034 & 533 & 488 \\
La Rioja & 220.729 & 444 & 497 \\
Mendoza & 1.414 .058 & 3.641 & 388 \\
Misiones & 789.677 & 977 & 808 \\
Neuquén & 388.934 & 799 & 487 \\
Rio Negro & 506.796 & 1.066 & 475 \\
Salta & 866.771 & 1.510 & 534 \\
San Juan & 529.920 & 1.243 & 426 \\
San Luis & 286.334 & 622 & 460 \\
Santa Cruz & 159.964 & 266 & 601 \\
Santa Fe & 2.797 .293 & 8.347 & 335 \\
Stgo. del Estero & 672.301 & 977 & 688 \\
Tucumán & 1.142 .247 & 3.019 & 478 \\
Terra Fogo & 69.450 & 89 & 780 \\
\hline Total & 32.608 .687 & 88.800 & 367 \\
\hline & & &
\end{tabular}


Em primeira instância, essa situação responde ao fato de que as Universidades em que os médicos se formam estão localizadas nos grandes centros urbanos (Buenos Aires, Córdoba, Mendoza, Rosário, La Plata, Tucumán e Corrientes) que, por sua vez, são os lugares que oferecem as maiores possibilidades de inserção profissional, concentrando a maior parte da renda e do desenvolvimento dos serviços em suas diversas modalidades e diferentes niveis de complexidade.

Essa característica facilita a incorporação ao mercado de trabalho, não apenas como autônomo mas também - principalmente nos últimos anos através de diversas formas de trabalho assalariado.

Cabe observar que, devido também às particularidades da estrutura de serviços, a maior parte da oferta de residências médicas concentra-se nos aglomerados urbanos. Esta primeira forma de inserção, ao mesmo tempo que garante uma remuneração mínima, constitui para o recém-formado um meio acessivel para completar a formação de graduação, em contato direto com os serviços - na maioria dos casos, pela primeira vez.

É sugestivo que os níveis de desemprego entre os médicos estejam muito abaixo daqueles de outras categorias profissionais, não somente no setor saúde. Um estudo da população médica da cidade de Rosário ${ }^{11}$ registrou uma grande capacidade do mercado para a incorporação dos médicos: do grupo pesquisado, apenas $9,1 \%$ não tinha trabalho remunerado no primeiro ano de formado, reduzindo-se essa proporção a $5,2 \%$ no segundo ano.

As situações de empregos mútiplos e subocupação também são características dos tipos de ocupação dos médicos. A primeira retrata a necessidade que têm os profissionais de aumentar sua renda com uma série de empregos em um ou mais subsistemas que compõem o setor, ou, ainda, combinando-os com alguma forma de prática autônoma.

A condição de subocupação provoca dois tipos de situações: a primeira, engloba os profissionais que investem na ocupação menos tempo do que estariam dispostos (subocupação por tempo); e a outra, de dimensão mais complexa, inclui aqueles que desempenham tarefas de menor qualificação do que aquelas para as quais eles foram capacitados (subocupação por qualificação).

Em geral, observa-se uma forte tendência à prática especializada, orientada desde a formação e reforçada pelas condições do mercado, amparada na crescente introdução de tecnologia e de instrumental complexo, e na conseqüente reorganização dos serviços.

Não existe informação completa a respeito do exercício das especialidades médicas, já que os mecanismos de habilitação são vários e não existe um registro único.

Diversos autores ${ }^{12}$ concordam que o grau de especialização na Argentina é bastante elevado, chegando a $50 \%$ ou $60 \%$ do total de

11 Belmartino S., Bloch C., Luppi I., Quinteros Z. e Troncoso M. del C.: Mercado de Trabajo e Médicos de Reciente Graduación. OPAs, Argentina, $\mathrm{n}^{\circ}$. 14, 1990. 
médicos. Esta proporção certamente aumenta em relação direta com a antiguidade no exercício profissional, chegando a incluir $80 \%$ dos médicos com mais anos de formado.

A partir de informações fornecidas pelas diversas associações e sociedades de especialistas é possível obter alguns dados que, devido às características das instituições que as forneceram, representam quantitativos mínimos correspondentes para cada especialidade. Em alguns casos, podem incluir outros profissionais não médicos que trabalhem na especialidade um número que, por ser pequeno, não chega a compensar o fato de que muitos dos especialistas em atividade não se filiaram às respectivas entidades (Tabela 5). Comparando a estimativa do número de médicos 88.800 - com o número de especialistas encontrado pelo mapeamento parcial das principais especialidades - 60.920 - pode-se constatar que em torno de $70 \%$ dos profissionais são especialistas.

\section{TABELA 5}

Estimativa do Número de Profissionais Médicos por Especialidade, Argentina 1992

\begin{tabular}{lr}
\hline Especialidade & Número de Médicos \\
\hline Clínica Médica & 18.000 \\
Pediatria & 8.000 \\
Cardiologia & 5.000 \\
Psiquiatria & 4.700 \\
Cirurgia & 3.600 \\
Oftalmologia & 3.400 \\
Ortopedia e Traumatologia & 3.200 \\
Ginecologia e Obstetrícia & 2.500 \\
Anestesiologia & 2.300 \\
Radiologia & 2.100 \\
Dermatologia & 2.000 \\
Otorrinolaringologia & 2.000 \\
Neurologia & 1.000 \\
Patologia & 1.000 \\
Endocrinologia & 850 \\
Nefrologia & 800 \\
Alergia e Imunologia & 550 \\
Urologia & 520 \\
Gastroenterologia & 500 \\
Diabetologia & 500 \\
Neurocirurgia & 400 \\
\hline Fon & \\
\hline
\end{tabular}

Fonte: Estimativa do autor com base em dados fornecidos pelas instituições consignadas no ANEXO III.

12 Belmartino S., Bloch C. et al.: op. cit.; Katz J., Muñoz A. et al.: op. cit.; Banco Mundial: op. cit. 


\section{Enfermagem}

Com base na estimativa realizada em $1989^{13}$, e de informações fornecidas pela Federación Argentina de Enfermeras, pode-se estabelecer a seguinte distribuição:

\begin{tabular}{ll}
\hline Enfermeiros (inclui licenciaturas) & 18.000 \\
Auxiliares de Enfermagem & 26.000 \\
Empiricos & 25.000 \\
\hline Total & 69.000 \\
\hline
\end{tabular}

Verifica-se que o número total, embora tenha registrado um aumento de $5 \%$ nos últimos três anos, não acompanha o crescimento populacional no mesmo período. A categoria correspondente ao pessoal com formação superior teria sofrido uma diminuição absoluta em razão da já citada emigração.

Assim, agrava-se a tradicional escassez de pessoal de enfermagem e aumenta a relação médico/enfermeiro em sentido contrário aos padrões universalmente aceitos. $O$ país contaria com 0,20 enfermeiros formados para cada médico, quando o recomendável é 3 enfermeiros por médico. Em 1992, a relação de enfermeiros por 10.000 habitantes diminui para 5,2.

A pequena oferta de pessoal de enfermagem foi confirmada pelos dados do Censo de População de 1980, que registrou 110.419 enfermeiros (dos quais $83 \%$ eram mulheres), ao passo que hoje esse número não chega a 70.000 . Esta diminuição de quase $40 \%$ afeta a prestação dos serviços.

Devido à divisão do trabalho dentro da categoria, a maioria das tarefas de enfermagem recai sobre o pessoal auxiliar e empírico ("atendentes"). É este pessoal, sem nenhum tipo de qualificação adicional para desempenho no serviço, que tem a seu cargo o atendimento direto na maioria das instituições.

Um estudo recente sobre enfermagem ${ }^{14}$ traz alguns dados reveladores sobre as dificuldades de suas condiçōes de vida e de trabalho. Além dos aspectos assinalados (pouco pessoal, baixos salários), as autoras verificaram que as jornadas de trabalho prolongadas, os plantões noturnos e em dias feriados, uma legislação inadequada às atuais características do trabalho juntamente com a tensão que implica o contato direto com a enfermidade e a morte, marcam a vida do pessoal de enfermagem.

13 Pesquisas de atualização realizadas pela área de Enfermagem da Dirección Nacional de Recursos Humanos e OPAS, 1989.

14 Wainerman C. e Geldstein R., Condiciones de vida y de Trabajo de las Enfermeras en la Argentina. Cuadernos del CENEP, $\mathrm{n}^{\circ}$. 44, Buenos Aires. 1990. 
Menção especial deve ser feita à predominância de mulheres trabathando em enfermagem. Embora seja uma característica histórica, parece ter se acentuado nos últimos anos, devido aos baixos níveis de remuneração que leva os homens cada vez mais a buscar oportunidades de trabalho melhor remuneradas.

\section{Odontologia}

Segundo dados obtidos por levantamentos recentes ${ }^{15}$, em 1991 trabathavam no setor cerca de 31.000 pessoas, das quais em torno de 23.000 $(74 \%)$ na categoria profissional (Tabela 6 ).

\section{TABELA 6}

Recursos Humanos em Odontologia Argentina, 1991

\begin{tabular}{lcr}
\hline Modalidade de prática & Odontólogos & $\begin{array}{c}\text { Assistentes } \\
\text { Odontológicos }\end{array}$ \\
\hline Particular Artesanal & 11.900 & 6.000 \\
Público & 2.300 & 900 \\
Semipúblico (obras filantrópicas & 6.400 & 400 \\
Empresarial (sistemas de pré-pagamento) & 2.300 & 800 \\
\hline Total & 22.900 & 8.100 \\
\hline
\end{tabular}

Fonte: Jaitt, Juan C., Prática Odontológica em América Latina. Investigación de Recursos Humanos, Acciones y Efectos de la Atención Odontológica, OFEDO-UDUAL-OPAS/OMS, Argentina, 1991.

Essa informação confirma a predominância da prática privada como forma de inserção ocupacional dos odontológos, o que não implica necessariamente em prática autônoma, já que sua renda provém de diversas fontes: convênios com empresas de saúde e sistemas de pré-pagamento, particulares etc.

De qualquer maneira, é significativo o número de profissionais em atividades "empresariais", que pressupõem a existência de sistemas de pré-pagamento de cobertura da saúde oral, nos quais a grande maioria dos odontólogos trabalha na condição de assalariado - o que constitui uma prática trabaIhista nova na Odontologia. Cerca de 1.300 profissionais trabalhariam exclusivamente nesta última modalidade, e os 1.000 restantes trabalhariam também em outros setores.

Merece também menção o grupo correspondente aos assistentes dentários, que abrange cerca de 8.100 pessoas. Sua distribuição por modalidade

15 Jaitt, Juan C., Práctica Odontológica en América Latina - Investigación de Recursos Humanos, Acciones y Efectos de la Atención Odontológica. OffDo-udual-oPAS/OMS, Argentina, 1991. 
ilustra as características diferenciais da prática odontológica: no setor privado, a relação é de 0,54 assistentes para cada odontólogo, ao passo que nas modalidades em que os profissionais são assalariados essa relação não passa de 0,14 .

\section{OUTRAS CATEGORIAS PROFISSIONAIS}

\section{Bioquímicos}

O desenvolvimento científico e tecnológico dos últimos 30 anos - sobretudo no campo da enzimologia, da imunologia, da físico-química e da biologia molecular - ampliou o horizonte do diagnóstico e determinou maior incidência dos critérios laboratoriais na formulação de diagnósticos clínicos e acompanhamento terapêutico.

Por sua vez, o desenvolvimento de novas tecnologias permitiu a difusão industrial e comercial de uma grande variedade de equipamentos de diagnóstico, que facilitaram o acesso da maioria dos bioquímicos a uma grande quantidade de técnicas antes limitadas a poucos.

Esse processo significou uma mudança na posição relativa dos bioquímicos no âmbito do pessoal de saúde, alterando as condições tradicionais de sua prática profissional.

Segundo estimativas das associações profissionais, cerca de 7.500 bioquímicos trabalham no país; por volta de $85 \%$ deles realizaria uma prática clínica nos diferentes subsetores, e os restantes teriam sua prática orientada para a indústria e a pesquisa. Na Capital Federal - onde se localizariam cerca de 2.000 bioquímicos - a modalidade de trabalho predominante é a relação de dependência nos 250 laboratórios particulares de análises clínicas e numa variedade de instituições de serviço públicas e particulares. No restante do país, a prática autônoma é a mais freqüente.

Apenas na Capital insinua-se uma tendência à especialização, acompanhando as condições gerais do mercado.

\section{Fisioterapeutas}

Trata-se de um campo de atividade profissional que sofreu significativa expansão nos últimos anos; entre 1980 e 1989, o número de fisioterapeutas egressos das Universidades cresceu numa taxa superior ao do conjunto dos graduados.

Seguindo a tendência predominante no sistema de educação superior, a maioria dos planos curriculares converteram-se em licenciaturas de cinco anos de duração.

A maior parte destes profissionais trabalha na Seguridade Social; sua participação no setor público é pequena, e menor ainda no setor privado. 
A reabilitação constitui a principal orientação da prática, em geral atendendo ao grupo da terceira idade. As atividades de prevenção, dirigidas a grupos de risco distintos, não têm significado.

É na prática da fisioterapia que se verifica uma das maiores proporções de mulheres trabalhando em saúde: cerca de $80 \%$ do total.

\section{Psicólogos}

Esta categoria profissional começou a desenvolver-se como disciplina autônoma no final da década de 50 , teve crescimento acelerado durante a década de 60 e hoje abrange cerca de 32.000 pessoas, segundo estimativas das entidades profissionais. Seu principal campo de atuação é a prática clínica autônoma, embora nos últimos anos - e a partir da regulamentação da lei de seu exercício - haja maior participação dos psicólogos em instituições assistenciais públicas e em obras filantrópicas.

Como conseqüência dessa prática predominante, a maior concentração de profissionais se verifica nos grandes centros urbanos, onde é maior a disponibilidade de recursos para financiar os tratamentos particulares. Assim, cerca de $75 \%$ dos profissionais concentram-se na Capital Federal e nas Províncias de Buenos Aires, Santa Fé e Córdoba; desses, $85 \%$ estão exercendo a profissão nos dois campos mencionados no parágrafo anterior.

\section{Assistentes Sociais}

Os assistentes sociais constituem uma das categorias não tradicionais mais numerosas: dos quase 11.000 profisisonais em atividade, cerca de $30 \%$ teria inserção ocupacional no setor saúde, trabalhando em hospitais públicos provinciais e municipais!160.

Essa inserção legitima-se no próprio processo de formação, a partir da recente institucionalização do sistema de residências de três anos para os assistentes sociais dentro do regime da carreira hospitalar, com equiparação aos demais profissionais de saúde.

\section{Engenheiros Sanitários}

Os engenheiros sanitários representam uma categoria profissional de crescente importância, como produto do reaparecimento de problemas de saúde gerados pela deterioração das condições ambientais e da infra-estrutura básica.

Estima-se que cerca de 1.000 profissionais estejam atuando no setor, dos quais 400 estariam formalmente capacitados (Pós-Graduação em Enge-

16 Estimativa do Centro de Estudios y Investigación em Trabajo Social (Diretor: Norberto Alayón), Buenos Aires, 1992. 
nharia Sanitária, da Faculdade de Engenharia da Universidade de Buenos Aires) e o restante com formação em outros ramos da Engenharia, tais como a Engenharia Hidráulica ou a Engenharia Civil17.

\section{A FORMAÇÃo DE RECURSOS HUMANOS}

Como comentado na introdução, o sistema formador de recursos humanos em saúde na Argentina constitui uma estrutura diversificada, integrada por instituições universitárias e de serviços, públicas e privadas, e ainda, centros de formação de técnicos em diferentes práticas da atividade assistencial (Tabela 7).

Essa estrutura de formação resulta da histórica acumulação de iniciativas a cargo de governos nacionais e provinciais, universidades públicas e particulares, empresas e instituições de serviço. Salvo em algumas carreiras, tal estrutura não foi submetida a qualquer instância de coordenação e regulação que definisse a qualidade e a quantidade dos recursos humanos que o país necessitaria.

Em conseqüência, nenhuma Escola ou Faculdade de Medicina foi criada na Argentina entre 1959 e 1991, ao passo que no resto da América Latina, para atender o crescimento da demanda de educação superior, este número multiplicou-se nas últimas três décadas.

Entre 1991 e 1992, exatamente nos momentos em que o ritmo de expansão do número de matrículas nos cursos superiores apresenta uma tendência à desaceleração, foram criadas e autorizadas a funcionar quatro escolas particulares, das quais apenas duas já entraram em funcionamento e as demais com previsão de funcionamento em 1994. Três delas estão localizadas na Capital Federal e uma na Província de Entre Ríos (Tabela 8).

\section{TABELA 7}

Estabelecimentos de Ensino Superior em Saúde Argentina, 1992

\begin{tabular}{lccc}
\hline Curso & Públicos & Particulares & Total \\
\hline Medicina & 7 & 6 & 13 \\
Odontologia & 8 & 2 & 10 \\
Enfermagem & 64 & 31 & 95 \\
Farmácia e Bioquímica & 11 & 3 & 14 \\
Nutrição & 4 & - & 4 \\
Psicologia & 6 & 7 & 13 \\
Serviço Social & 53 & - & 70 \\
Veterinária & 8 & 1 & 8 \\
Fisioterapia & 3 & - & 4 \\
Engenharia Sanitária & 1 & 1 & 1 \\
\hline
\end{tabular}

Fonte: Dirección de Asuntos Universitários. Ministerio de Cultura y Educación.

17 Estimativa da Asociación Interamericana de Ingenieria Sanitaria (AIDIS). 


\section{TABELA 8}

Tipologia de Faculdades de Medicina por Números de Alunos Argentina, 1992

\begin{tabular}{lccc}
\hline Número de Alunos & Fac. Públicas & Fac. Particulares & Total \\
\hline Menos de 250 & - & 4 & 4 \\
De 250 a 500 & - & - & - \\
De 500 a 1.500 & - & - & - \\
Mais de 1.500 & 7 & 2 & 9 \\
\hline Total Geral & 7 & 6 & 13 \\
\hline
\end{tabular}

Fonte: Elaboração do autor com base em dados do Min. de Cultura e Educação da Argentina.

$\mathrm{Na}$ Argentina, com algumas exceções, a maior parte da formação de outras categorias profissionais - como fisioterapeutas, parteiras, nutricionistas, fonoaudiólogos - é realizada em escolas subordinadas às Faculdades de Medicina.

A formação de odontólogos e a de farmacêuticos e bioquímicos é realizada em faculdades independentes.

A formação de pessoal de enfermagem é realizada em nivel universitário e não universitário com uma grande dispersão, tanto no tipo quanto no número de instituições formadoras de cada uma das duas categorias: profissionais e auxiliares.

Quanto às condições para o ingresso nas carreiras de saúde, não existe um número preestabelecido de vagas, desde a recuperação democrática em 1983.

No entanto, algumas Faculdades de Medicina têm imposto severas restriçōes ao ingresso de estudantes, configurando verdadeiros "numerus clausus". Tal é o caso de universidades como as de Mendoza e La Plata, e é o que pretende fazer a Faculdade de Medicina de Buenos Aires, atualmente em conflito com o colegiado que dirige a Universidade.

Na maioria dos casos, o mecanismo para o ingresso é um exame eliminatório ou um curso de ingresso com exame final. Na Universidade de Buenos Aires o sistema de acesso é atípico, porque desde 1985 os alunos, para ingressar em qualquer faculdade, devem ser aprovados no Ciclo Básico Comúm (CBC).

Esse ciclo consta de seis matérias, que variam de acordo com a faculdade/carreira escolhida, com uma duração teórica de dois quadrimestres letivos. A aprovação do $\mathrm{CBC}$ completo habilita o estudante a ingressar automaticamente na carreira escolhida. Em média, ingressam na Faculdade de Medi- 
cina, por ano, $25 \%$ dos alunos que começaram a cursar O $\mathrm{CBC}$ no ano anterior; outra importante percentagem só o faz ao final de dois anos.

Em geral, não existem no país disposições que estabeleçam algum tipo de exame especial para obter-se o diploma, já que a aprovação completa das matérias que compõem o currículo constitui requisito suficiente para a obtenção do título. De acordo com a norma vigente, uma vez formados, os profissionais podem iniciar o exercício da profissão, sem outra condição além da inscrição no órgão regulamentador oficial.

Pode-se afirmar que, de maneira geral, a formação de recursos humanos em saúde encontra-se em fase crítica. A maior parte das universidades e dos centros de formação públicos, nos quais se formam cerca de $95 \%$ dos profissionais do setor, experimentaram um severo corte nas dotações orçamentárias provenientes do Estado. Essa redução cria sérias dificuldades, pois a pouca dedicação dos professores, em razão dos níveis decrescentes de remuneração, soma-se à escassez de recursos para sustentar os gastos de equipamento, funcionamento e manutenção que o exercício da docência exige.

Cabe registrar que em março de 1992 o salário médio de um professor adjunto com dedicação simples (categoria que abarca cerca de $63 \%$ dos professores) e 10 anos de antiguidade, chegava a US $\$ 120$ mensais (Tabela 9).

Dentro desse quadro surge uma série de conflitos, que incluem greve de professores e suspensão ou diminuição de atividades fundamentais, como o trabalho prático. As universidades, ou alguns setores delas, saem em busca de fontes alternativas de financiamento - entre elas, diversas formas de privatização de áreas básicas ou clínicas.

Essa estratégia, entretanto, fortalece conflitos, pois vai contra a tradicional autonomia das universidades e as coloca numa situação de maior dependência em relação às contingências de um mercado que cotidianamente redefine as características da prática profissional.

Neste contexto, parece necessário instaurar um debate, que ainda sequer se insinua, a respeito da necessidade de reformular um modelo de formação que, por suas características, não prepara o formado para desenvolver uma prática orientada para o atendimento às necessidades da maioria dos setores sociais.

Ao contrário, o modelo de prática que parece ter se consolidado é aquele que, superespecializado no ritmo da complexidade tecnológica, realiza intervenções de curto alcance, às quais só têm direito os grupos sociais de maiores recursos. 


\section{TABELA 9}

Docentes por Categoria e Horário

Universidade de Buenos Aires, Faculdade de Medicina

\begin{tabular}{lrrr}
\hline Categoria & 1980 & 1985 & 1989 \\
\hline Titular DE $^{(1)}$ & 17 & 6 & 19 \\
Titular DSE $^{(2)}$ & 38 & 56 & 38 \\
Titular DS $^{(3)}$ & 24 & 64 & 94 \\
Assistente DE & 2 & 1 & - \\
Assistente DSE & - & - & - \\
Assistente DS & 4 & 4 & 14 \\
Adjunto DE & 27 & 28 & 36 \\
Adjunto DSE & 16 & 18 & 18 \\
Adjunto DS & 272 & 274 & 389 \\
Chefe Trabalhos Práticos DE & 55 & 23 & 71 \\
Chefe Trabalhos Práticos DSE & 31 & 48 & 51 \\
Chefe Trabalhos Práticos DS $_{\text {Ajudante 1* DE }}^{*}$ DS & 251 & 300 & 436 \\
Ajudante 1* DSE & 34 & 5 & 33 \\
Ajudante 1" DS & 11 & 20 & 20 \\
Ajudante 2 & 474 & 515 & 639 \\
\hline Total & 421 & 501 & 620 \\
\hline
\end{tabular}

(1) $\mathrm{DE}=$ Dedicação Exclusiva

(2) DSE = Dedicação Semi-Exclusiva

(3) $\mathrm{DS}=$ Dedicação Simples

Fonte: Secretaria de Assuntos Académicos da UBA, com dados da Facultad de Medicina e da Dirección General de Presupuesto ye Control Presupuestario da UBA.

Essa estratégia, entretanto, fortalece conflitos, pois vai contra a tradicional autonomia das universidades e as coloca numa situação de maior dependência em relação às contingências de um mercado que cotidianamente redefine as características da prática profissional.

Neste contexto, parece necessário instaurar um debate, que ainda sequer se insinua, a respeito da necessidade de reformular um modelo de formação que, por suas características, não prepara o formado para desenvolver uma prática orientada para o atendimento às necessidades da maioria dos setores sociais.

Ao contrário, o modelo de prática que parece ter se consolidado é aquele que, superespecializado no ritmo da complexidade tecnológica, realiza intervenções de curto alcance, às quais só têm direito os grupos sociais de maiores recursos. 


\section{Médicos}

A supressão dos sistemas de ingresso e vagas, vigentes durante os anos de ditadura militar, permitiu em 1984 o ingresso de 15.000 novos alunos nas Faculdades de Medicina do sistema nacional. Assim, o número total de matriculados elevou-se a 50.000 estudantes em 1985.

A partir de 1988 registra-se uma tendência à diminuição no número de matriculados. Desse modo, o número anual de egressos do sistema nacional, que no início da década rondava os 5.000 (como conseqüência do ingresso maciço no período 1973-1975), reduziu-se a cerca de 3.000 médicos por ano na segunda metade da década de 80 e, confirmada essa tendência, ficaria estabilizado em cerca de 3.300 na década de 90 (Tabela 3).

Simultaneamente - e em particular na Universidade de Buenos Aires, que concentra mais de $30 \%$ dos alunos de Faculdades de Medicina do sistema nacional, verifica-se uma diminuição da participação relativa dos estudantes da carreira médica no total de alunos da Faculdade, conseqüência do crescimento de outras carreiras, em especial Fisioterapia, Fonoaudiologia e Nutrição.

Hoje se defende, na maioria das universidades, a necessidade de restringir o ingresso ao curso universitário de Medicina, a partir do pressuposto de que o número de médicos no país é excessivo. No entanto, não é defendida a necessidade de reformulação acadêmica da perspectiva em torno da qual os currículos são estruturados, com a finalidade de satisfazer as demandas sociais. Pelo contrário: reforçam-se as orientações a-históricas, fragmentadas e paliativas, ignorando os modelos que postulam uma formação integral, interdisciplinar, integrada com os serviços e que, a partir de uma contextualização do processo saúde/doença como problema e necessidade social, favoreça o questionamento e as mudanças necessárias da prática e do modelo de atendimento.

É necessário considerar, em primeira instância, que esse excedente surge da incapacidade de absorção do modelo de atendimento vigente, que, por suas características, exclui do acesso aos serviços setores cada vez mais amplos da população.

A experiência internacional ilustra que a decisão quanto ao número de profissionais médicos de que o país necessita não é, em caso algum, de competência exclusiva das Escolas de Medicina, geralmente orientadas pelos interesses específicos de grupos corporativos. Essa decisão deve resultar de uma ação coordenada entre os órgãos do governo e as instituições de serviços e de formação, uma vez devidamente avaliado o conjunto das necessidades sociais.

Nos últimos anos realizaram-se algumas tentativas de desenvolver modelos de formação nessa perspectiva; entre elas, merece destaque o modelo 
da Universidade de Buenos Aires, que desde 1990 encontra dificuldades para colocá-lo em prática ${ }^{18}$.

Por outro lado, a tradição acadêmica, fragmentária, teórica e tendendo a uma especialização precoce na formação dos profissionais graduados no campo das ciências da saúde já constitui um fato histórico.

Por sua vez, o desenvolvimento tecnológico e as condições do mercado pressionam, com força crescente, as tendências à especialização e à subespecialização. No Anexo II está transcrita uma listagem parcial das especialidades médicas reconhecidas no país. Segundo a Dirección de Control del Ejercicio Profesional y de las Especialidades Médicas, a lista completa, ainda não copilada, teria o dobro do tamanho.

Às deficiências conjunturais observadas na formação de graduação juntam-se a rigidez estrutural que caracteriza as instituições acadêmicas, impedindo-as de incorporar, com a necessária rapidez, as mudanças tecnológicas e o volume de informações adicionais indispensáveis ao seu desenvolvimento. Em conseqüência, a formação de pós-graduação torna-se uma etapa imprescindivel para completar a capacitação profissional.

Essa formação se realiza fundamentalmente no setor público, através de residências médicas e cursos de especialização, bem como dos colegiados e associações profissionais, que orientam sua oferta segundo as condições de prática vigentes no mercado.

De acordo com informações disponíveis da Universidade de Buenos Aires, enquanto o número de formados no curso de Medicina diminuiu de 2.189 em 1980 para 1.141 em 1989, o número de títulos outorgados a médicos especialistas no mesmo período passou de 341 para 712 , o que significa que, enquanto o número de médicos formados decresceu em $48 \%$, o de especialistas cresceu $109 \%$. Enquanto em 1980 os títulos de especialização representavam 15\% dos diplomas fornecidos pela Faculdade, em 1989 constituíam $62 \%$ deles.

Se somarmos os especialistas formados nas universidades aos que obtêm sua especialização através de algum dos tantos mecanismos disponíveis no mercado, podemos ter uma idéia da dimensão do problema de habilitação e de garantia de qualidade no exercício profissional.

\section{Enfermagem}

Atualmente, e apesar da escassez de pessoal nessa categoria ou em conseqüência dela, a formação de enfermeiros se desenvolve em 95 instituições, das quais 21 são de nível universitário, 45 de nível superior não universitário, subordinadas ao Ministério da Educação e ao Ministério da Saúde, e

18 Uma sintese das principais características dessa proposta foi publicada em Educación Médica y Salud, Vol. 26 (3), OPAS/OMS, 1992. 
29 na órbita do Ministério da Educação através do Servicio Nacional de Enseñanza Privada (SNEP).

Também no caso da enfermagem pode-se afirmar que a formação em qualquer das instâncias realiza-se a partir de currículos desintegrados, que enfocam os aspectos curativos da prática e os componentes biológicos do processo saúde/doença, sem considerar os condicionantes sociais a partir dos quais esses processos ocorrem.

$O$ contingente formado em programas de três a cinco anos incorporase ao mercado de trabalho com uma série de limitações que, somadas à oferta praticamente inexistente de opções de formação de especialização em campos específicos e ao escasso reconhecimento social desses profissionais, determinam condições de vida e de trabalho pouco estimulantes.

Essa situação, à qual vem juntar-se o baixo nível de remuneração, explica a escassez de enfermeiros no país, tanto em nível de auxiliares como no de profissionais.

E reduzido o número anual de ingressos e de graduados nas diversas Escolas, e em geral é grande o índice de evasão escolar; segundos dados de uma pesquisa ${ }^{19}$, para algumas Escolas a evasão anual chegaria a $94 \%$, e a média ficaria em torno de $60 \%$.

Esse fato faz com que no total do país o número de formados por ano seja reduzido. Segundo a Federación Argentina de Enfermería, entre 1990 e 1992 formaram-se 800 enfermeiros, dos quais $50 \%$ na Capital Federal e na Província de Buenos Aires, e cerca de 4.000 auxiliares em todo o país.

Cabe assinalar que segundo a lei que regula o exercício (Lei 24.004), pertence à categoria "profissional" toda pessoa que, com nivel secundário, complete uma formação de mais de três anos de nível superior. Na categoria de auxiliares incluem-se aqueles que, tendo completado seus estudos primários, realizem um curso de nove meses de duração em estabelecimentos reconhecidos oficialmente. Por último, a categoria dos empíricos (atendentes) - a mais numerosa no país - compreende as pessoas que, independentemente de sua qualificação formal, capacitaram-se através da experiência.

\section{FORMAÇÃO EM SAÚdE PÚBLICA}

Para completar este quadro, é preciso uma consideração sobre a formação em saúde pública, que enfrenta hoje em dia, em quase toda a América Latina, o grande desafio de reformular seus programas para dar uma resposta eficiente às necessidades reais da população, ante a velocidade e a profundidade das mudanças que estão sofrendo as suas condições de saúde.

19 Pesquisa exploratória das Escolas de Enfermaria. Dirección Nacional de Recursos Humanos OPAS, Argentina, 1990. 
De modo geral, pode-se afirmar que na Argentina mantêm-se, neste campo, as características predominantes nos anos 60 , não havendo surgido nesses anos - salvo algumas tentativas isoladas, de curto alcance e pequeno impacto - mudanças na estrutura das instituições formadoras, nem em sua vinculação com os serviços de saúde e com o modelo de atendimento; não modificou-se a orientação dos cursos que elas oferecem, nem das pesquisas que realizam.

Nesse quadro, a formação em Saúde Pública na Argentina caracterizase por uma grande dispersão de instituições e de propostas.

Um estudo recente, realizado com o objetivo de identificar as tendências gerais da formação de pós-graduação em Saúde Pública ${ }^{20}$, registra que em 1991 existiam no país 51 instituições que ofereciam programas de pósgraduação em Saúde Pública ${ }^{21}$. Entre elas, verifica-se uma importante participação de instituições não-acadêmicas, pois apenas $31 \%$ do total são acadêmicas na área da saúde e as restantes correspondem a instituições sindicais, de serviço, de governos provinciais ou nacionais e a instituições acadêmicas fora do campo das saúde.

$\mathrm{Na}$ época da realização da pesquisa, as instituições observadas ofereciam, em conjunto, 76 programas de formação, dos quais apenas 57 realmente se desenvolviam. Segundo a regulamentação vigente na maior parte das instituições acadêmicas, quase metade corresponderia a cursos de especialização, isto é, com duração entre 400 e 600 horas letivas.

A superioridade das instituições não acadêmicas destaca-se também em relação ao número de alunos. Do total de alunos egressos desses programas em 1990, 72\% vinham de instituições não acadêmicas; segundo os dados disponíveis, em 1991 essa proporção se mantinha estável, e ao mesmo tempo verificava-se um incremento no número de matrículas em instituições acadêmicas não pertencentes à área das saúde e em programas desenvolvidos por instituições privadas, em convênio com órgãos oficiais.

A pequena importância dada à formação nesse campo fica evidenciada pelo pequeno número de bolsas de estudo, fato que, tratando-se de graduados, constitui uma limitação à sua participação. $O$ oposto ocorre nos programas oferecidos por instituições públicas provinciais, muitos dos quais possibilitam a capacitação dos alunos em serviço, mantendo a remuneração estabelecida.

Quanto ao quadro docente, observa-se que é pequena a participação de professores das categorias superiores: apenas $20 \%$ são titulares e assisten-

20 Encuesta a Programas e Instituciones de Salud Pública (Diretor: Dr. Henrique Stein), OPAS/AESPA. Em: Reunión sobre Formación de Posgrado em Salud Pública en la República Argentina. Publicação $n^{2}$. 33, OPAS/OMS-AESPA, Argentina, 1992.

21 O estudo não incluiu o mapeamento de instituições com programas de duração inferior a 400 horas letivas. 
tes. Por outro lado, é muito baixa a dedicação do corpo docente: $70 \%$ do conjunto tem dedicação simples (entre 12 e 20 horas semanais, dependendo da instituição), e apenas $5 \%$ oferece dedicação exclusiva.

Em finais de 1993 registram-se duas propostas que tentam dar respaldo institucional a uma concepção e a uma prática de Saúde Pública adequada à complexidade das mudanças e as necessidades de saúde da população. A primeira é um Mestrado recentemente aprovado pela Universidade de Buenos Aires, cuja implementação será compartilhada por um grupo significativo de faculdades; a segunda iniciativa, em vias de aprovação, é um Mestrado a ser desenvolvido de forma conjunta pelo Município de Rosário, a Universidade Nacional de Rosário e a Associação Médica de Rosário.

\section{REGULAMENTAÇÃo E HABILITAÇÃo}

O corpo normativo que regula o exercício da atividade dos profissionais de saúde estrutura-se basicamente em torno da Lei 17.132/67 e dos decretos que a regulamentam. Seu Artigo 43 possibilita a incorporação de atividades de apoio. Nelas enquadram-se os podólogos, os técnicos em histopatologia e os instrumentadores.

Leis posteriores regulamentaram o exercício profissional de outras categorias, como as dos psicólogos, protéticos dentais e enfermeiros.

Recentemente importantes modificações foram introduzidas no Artigo 21, que regulamenta as especialidades médicas, e no Artigo 31, que trata do exercício das especialidades odontológicas.

A atividade farmacêutica, no que diz respeito tanto à prática profissional quanto à licença de farmácias, é reguladas pela Lei 17.565 e suas emendas.

As atividades profissionais não mencionadas são regidas pela Lei $17.132 / 67$.

Os diplomas são expedidos pelas Universidades, e o registro profissional é outorgado, no âmbito da Capital Federal, pela Dirección Nacional de Control del Ejercicio Profesional y de las Especialidades Médicas (Tabela 10). $\mathrm{Em}$ algumas províncias existem colegiados que habilitam quase todos os profissionais. No resto do país, os responsáveis pelo registro são órgãos subordinados ao Ministério da Saúde da jurisdição.

Os colegiados profissionais são os órgãos responsáveis pela ética e a deontologia do exercício profissional.

Hoje em dia começa a definir-se uma polêmica em torno de qual ou quais deveriam ser os órgãos reguladores da habilitação profissional, mas ainda não se pode precisar se haverá, a curto prazo, mudanças na legislação.

Os graduados em cursos universitários no estrangeiro devem efetuar a revalidação de seu diploma para poderem exercer a profissão; no caso de profissionais provenientes de países com os quais existe convênio, trata-se 
de um mecanismo administrativo de trâmite automático; em outros casos, a revalidação exige exames de equivalência ou de complementação. Esse aspecto terá grande importância no futuro próximo, no campo das políticas de integração regional (MERCOSUL).

No que diz respeito ao exercício das especialidades, são três as principais instâncias de habilitação:

1) as universidades, através de cursos de especialização;

2) os colegiados médicos e as associações profissionais;

3) os serviços reconhecidos a partir de um período de cinco anos de exercício em determinada especialidade.

Como conseqüência dessa diversidade, os requisitos não são homogêneos. $O$ custo de muitos deles também age como mecanismo diferenciador, embora nem sempre se possa associar o custo à qualidade.

Quanto aos mecanismos de revalidação de certificados, só existem normas estabelecidas por alguns colegiados, como o de Córdoba. No âmbito da Capital Federal, e a partir de $1^{\circ}$. de março de 1993, foi regulamentado um regime de revalidação de certificados de especialistas a cada cinco anos, sob a jurisdição da Secretaria de Saúde subordinada ao Ministério da Saúde e Ação Social. A revalidação será realizada através de uma avaliação de antecedentes e um exame específico. Esse mecanismo ainda não foi implementado, e, por sua envergadura, para ser colocado em andamento requer a formalização de convênios com os serviços.

TABELA 10

Regulamentação Geral do Exercício Profissional

\begin{tabular}{l|l|l|l|r}
\hline Curso & Duração & Diploma & Expedição & Lei-Exerc. \\
\hline Medicina & 6 anos & Universitário & Universitário & $1713-2 / 67$ \\
Odontologia & 5 anos & Universitário & Universitário & $1713-2 / 67$ \\
Enfermagem & 4 anos & Universitário & Universitário & $2400-4 / 91$ \\
Farmácia & 5 anos & Universitário & Universitário & $1756-5 / 78$ \\
Bioquímica & 6 anos & Universitário & Universitário & $1713-2 / 67$ \\
Psicologia & 6 anos & Universitário & Universitário & $2327-7 / 85$ \\
Nutrição & $4-5$ anos & Universitário & Universitário & $1713-2 / 67$ \\
Serviço Social & $4-5$ anos & Universitário & Universitário & $2337-7 / 86$ \\
Enfermagem Aux. & $2-3$ anos & Superior ñ/univ. & Escolas & $2499-4 / 91$ \\
Técnico e & 3 anos & Universitário & Universitário & - \\
Aux. Lab. & 2 anos & Superior & Escolas & $1713-2 / 67$ \\
Técnico e & 2 anos & Universitário & Universitário & - \\
Aux. Raio-X & 2 anos & Superior & Escolas & $1713-2 / 67$ \\
Fisioterapia & $4-5$ anos & Universitário & Universitário & $1713-2 / 67$ \\
\hline
\end{tabular}

Fonte: Estimativa do autor com base em dados fornecidos pelo Ministério de Cultura e Educação e Ministério de Saúde e Ação Social da Argentina. 


\section{ANEXO II}

\section{RELAÇÃO DE ESPECIALIDADES MÉDICAS}

Alergia, Anatomia Patológica, Anestesiologia, Angiologia, Bacteriologia, Cardiologia, Cirurgia Cardiovascular, Cirurgia de Cabeça e Pescoço, Cirurgia Geral, Cirurgia Plástica, Cirurgia Toráxica, Cirurgia Vascular e Periférica, Clínica Médica, Dermatologia, Dermatosifilografia, Diagnóstico por Imagens: (radiologia, radiodiagnóstico, tomografia computadorizada, ecografia, ultra-sonografia), Endocrinologia, Endoscopia Digestiva, Doenças Infecciosas, Epidemiologia, Farmacologia, Fisiatria, Gastroenterologia, Genética, Geriatria, Ginecologia, Hemoterapia, Hematologia, Higiene Industrial, Higiene e Medicina Preventiva, Imunologia, Leprologia, Mastologia, Medicina Aeronáutica e Espacial, Medicina Esportiva, Medicina do Trabalho, Medicina Legal, Medicina Nuclear, Medicina Sanitária ou Administração Hospitalar, ou Saúde Pública, Nefrologia, Neurocirurgia, Neurologia, Nutrição, Oftalmologia, Obstetrícia, Oncologia, Ortopedia e Traumatologia, Otorrinolaringologia, Pediatria, Pneumonologia, Protologia, Psicologia Médica, Reumatologia, Terapia Radioativa (Cobaltoterapia, Radioterapia, Radiumoterapia e Isótopos radioativos com fins terapêuticos), Terapia Intensiva, Tisiologia, Tisiopneumonologia, Tocoginecologia, Toxicologia, Urologia.

\section{RELAÇÃO DE ESPECIALIDADES PEDIÁTRICAS}

Clínica Pediátrica, Cardiologia Infantil, Cirurgia Infantil, Nefrologia Infantil, Neurologia Infantil, Neonatologia, Psiquiatria Infantil. 


\section{ANEXO III}

\section{RELAÇÃO DE INSTITUIÇÕES E ORGANISMOS CONSULTADOS}

Asociación Argentina de Alergia e Inmunología

Asociación Argentina de Cirugía

Asociación Argentina de Dermatología

Asociación Argentina de Dietistas y Nutricionistas Dietistas

Asociación Argentina de Neurocirugía

Asociación Argentina de Ortopedia e Traumatología

Asociación Bioquímica Argentina

Asociación Fonoaudiológica Argentina

Asociación Interamericana de Ingenieros Sanitarios

Asociación de Psiquiatras Argentinos

Centro de Estudios e Investigación en Trabajo Social

Confederación Farmacéutica Argentina

Confederación Médica de la República Argentina

Confederación Unificada de Bioquímicos de la República Argentina

Confederación de Kinesiólogos y Fisioterapeutas de la Rep. Argentina

Dirección Nacional de Estadísticas de Salud - Secretaría de Salud -

- Ministerio de Salud y Acción Social

Dirección Nacional de Control y Regulación del Ejercicio Profesional y de las Especialidades Médicas - Secretaría de Salud -

- Ministerio de Salud y Acción Social

Escuela de Nutrición de la Universidad de Buenos Aires

Federación Argentina de Asociaciones de Anestesiología

Federación Argentina de Cardiología

Federación Argentina de Enfermería

Federación Argentina de Graduados de la Rep. Argentina en Nutrición

Federación Argentina de Sociedades de Endocrinología

Federación Argentina de Sociedades de Ginecologia y Obstetricia

Federación Argentina de Sociedades de Otorrinolaringología

Federación Argentina de Trabajadores de la Sanidad

Federación de Profesionales Municipales

Federación de Psicólogos de la República Argentina 
Sociedad Argentina de Alergía e Inmunopatología

Sociedad Argentina de Cardiología

Sociedad Argentina de Cirugía Plástica

Sociedad Argentina de Coloproctología

Sociedad Argentina de Dermatología

Sociedad Argentina de Diabetes

Sociedad Argentina de Ecografía e Ultrasonografía

Sociedad Argentina de Endocrinología y Metabolismo

Sociedad Argentina de Gasteroenterología

Sociedad Argentina de Nefrología

Sociedad Argentina de Neurología

Sociedad Argentina de Nutrición

Sociedad Argentina de Oftalmología

Sociedad Argentina de Otorrinolaringología

Sociedad Argentina de Patología

Sociedad Argentina de Pediatría

Sociedad Argentina de Radiología

Sociedad Argentina de Urologia

Sociedad de Medicina Veterinaria 


\title{
EsTUDO DE CONDIÇÕES DE FORMAÇÃO E EXERCÍCIO PROFISSIONAL EM SAÚDE NO BRASIL
}

\author{
Mario Roberto Dal Poz \\ Tereza Christina Varella
}

\section{CONSIDERAÇÕES INICIAIS}

Este documento, preparado como subsídio à reunião de Montevidéu, Uruguai, é uma abordagem preliminar das condições de formação e exercício profissional em saúde no Brasil. A preocupação maior do texto, ao sobressair dados e séries, é a caracterização do conjunto da problemática, de maneira clara e sintética, permitindo sua compreensão e utilização por diferentes interlocutores.

Algumas questões, como se verá, são comuns às diferentes categorias profissionais. Dentre essas questões se encontram os mecanismos de ingresso nas instituições de ensino superior, que permitem o acesso aos estudantes que concluem o $2^{2}$ grau. As provas seletivas são realizadas, anualmente, pela associação entre as diversas universidades ou faculdades isoladas, públicas ou privadas. Essas provas são elaboradas com base no conteúdo das disciplinas e conhecimentos exigidos no $2^{\circ}$ grau. A modalidade de prova não é, obrigatoriamente, a mesma, pois os critérios podem variar segundo o Estado ou grupo de instituições. 
Os estudantes estrangeiros podem inserir-se em cursos ou programas desenvolvidos, no país, a partir dos mecanismos decorrentes dos acordos culturais e científicos, em três modalidades:

1. Nos cursos de graduação, o ingresso independe de aprovação no processo seletivo das instituições de ensino. Os alunos são encaminhados do país de origem já com habilitação para o curso escolhido, pelo consulado brasileiro, que se responsabiliza por atestar a suficiência no idioma nacional;

2. Nos programas de especialização similares à Residência Médica o procedimento é o mesmo da graduação, apenas o processo seletivo é feito nas próprias instituições de ensino ou serviços credenciados, pela análise curricular dos candidatos. Os interessados devem comprovar condições de sustento próprio no período do curso, pois não existem bolsas para este tipo de programa;

3. Na pós-graduação stricto sensu são oferecidos cursos de nível de Mestrado e Doutorado, avaliados pela Cordenadoria de Aperfeiçoamento de Pessoal de Nivel Superior - CAPES - como nível "A" ou "B" e a seleção é realizada por via documental.

No que se refere ainda à pós-graduação, foi incluído no final do documento uma breve análise dos programas e cursos de mestrado e doutorado agrupados sob a denominação de "profissões da saúde".

Apesar de autorizado pela nova Constituição, até hoje não foi regulamentado o "serviço civil obrigatório". As tentativas de encaminhamento desta questão não se concretizaram, encontrando resistência no meio estudantil. $\mathrm{O}$ assunto tende a ficar esquecido, neste momento, face à inexistência de opinião consensual sobre o problema.

A análise da oferta de empregos pelas instituições de saúde, a partir de 1987, foi prejudicada, em parte, pela exclusão de dados de recursos humanos no "Inquérito sobre Assistência Médico-Sanitária", desenvolvido pelo Instituto Brasileiro de Geografia e Estatística. Muitos dados foram obtidos com o Sistema de Informações de Recursos Humanos, da Coordenação Geral de Desenvolvimento de Recursos Humanos para o sus, do Ministério da Saúde e nos Conselhos Profissionais.

Algumas tendências, no entanto, podem ser claramente observadas ${ }^{1}$. A participação feminina na força de trabalho em saúde continua aumentando. No período $70 / 80$, a participação feminina cresceu de 40 para $60 \%$ do total da FTS. Esse processo repercute fortemente no nível de remuneração dos profissionais, pois, historicamente, a mão de obra feminina tem sido menos remunerada relativamente.

1 Girardl, S. N., A estrutura ocupacional da saúde no Brasil, Min. Saúde, Brasília, 1990. (Mimeo). 
O aumento do número de horas trabalhadas, associado ao multiemprego, mesmo no setor público tornou-se comum entre os profissionais de saúde, numa tentativa de compensar as perdas salariais, estendendo-se inclusive ao pessoal de enfermagem, .

Outro aspecto a ressaltar é o crescimento da forma assalariada e a redução de espaço, no mercado, para os profissionais na condição de autonomo. Na década de 70/80, o número de profissionais autonomos passa de $42,8 \%$ para $33.6 \%$ da FTS.

Em relação à oferta de emprego existe hoje uma tendência ao fortalecimento da esfera municipal. No bojo das transformações que se processam com a implantação do sus e a conseqüente descentralização dos serviços e ações de saúde, houve uma mudança no eixo do oferecimento de vagas públicas. Este processo deverá ser cada vez mais acentuado em face de aposentadoria e outras modalidades de afastamento definitivo daqueles que estão empregados em estabelecimentos federais e estaduais municipalizados. Caberá às municipalidades a absorção destes postos de trabalho.

As correntes migratórias internas são claramente observadas, na área de saúde, no processo de busca de qualificação/especialização. Percebe-se um fluxo constante, das regiões norte e nordeste, para a região sudeste, de candidatos e alunos para programas de residência médica e mestrado/doutorado.

Outra tendência que se mantém, desde os anos 70 , é o crescimento de participação dos profissionais de nível médio no mercado de trabalho.

A relação empregatícia da maior parte das instituições públicas de saúde é de natureza efetiva, com estabilidade para o funcionário. A lei que estabeleceu o regime jurídico único para os servidores públicos federais foi reproduzida na maioria do estados e municípios brasileiros.

No processo de realização da $8^{a}$ Conferência Nacional de Saúde, em 1986, constituiu-se um colegiado denominado "Plenária Nacional de Saúde" que tem se mantido razoavelmente organizado e reivindicante. Sua composição, bastante ampla, incluiu a maioria dos conselhos federais e estaduais das profissões de saúde, as federações nacionais, sindicatos, associações profissionais das mais diversas, bem como associações de moradores e outras, como as de pacientes renais crônicos. Sua atuação tem sido mais intensa junto ao Conselho Nacional de Saúde e ao próprio Ministério da Saúde.

\section{MÉdicos}

\section{Formação}

\section{Graduação}

Após a criação em 1808, da Escola de Cirurgia no Hospital Real na Bahia e a fundação da Escola Anatômica, Cirúrgica e Médica do Rio de 
Janeiro ${ }^{2}$, o processo de formação de novas escolas médicas no Brasil passou a ocorrer em ciclos, atendendo, em cada período e conjuntura, aos variados interesses políticos, econômicos ou tecnico-científicos.

Em dois períodos o surgimento de novas escolas médicas teve características quase de "surto": de 1950 a 1964 (23 novas escolas, ou seja, quase duas escolas por ano) e de 1965 a 1971 ( 37 escolas, ou seja, seis escolas novas por ano). Nos anos recentes foram poucas as novas escolas médicas criadas.

\section{TABELA 1}

Distribuição dos Cursos de Medicina, Segundo o Período de Criação, Brasil

\begin{tabular}{lc}
\hline Período & $N^{*}$ de Escolas \\
\hline até 1900 & 4 \\
de 1901 a 1950 & 9 \\
de 1950 a 1964 & 23 \\
de 1965 a 1971 & 37 \\
de 1972 a 1992 & 7 \\
\hline
\end{tabular}

Fonte: MEC.

TABELA 2

Distribuição de Cursos de Medicina Segundo a Dependência da Instituição Mantenedora, Brasil, 1990

\begin{tabular}{lccccccc}
\hline $\begin{array}{l}\text { Dependência } \\
\text { Administrativa }\end{array}$ & Norte & Nordeste & Sudeste & Sul & $\begin{array}{c}\text { Centro } \\
\text { Oeste }\end{array}$ & Brasil & $\%$ \\
\hline Federal & 2 & 10 & 9 & 7 & 4 & 32 & 40,0 \\
Estadual & 1 & 2 & 5 & 2 & 0 & 10 & 12,5 \\
Municipal & 0 & 0 & 2 & 1 & 0 & 3 & 3,8 \\
Privada & 0 & 1 & 28 & 6 & 0 & 35 & 43,7 \\
\hline Total & 3 & 13 & 44 & 16 & 4 & 80 & 100,0 \\
\hline
\end{tabular}

Fonte: SIRH/CCDRH.SUS/MS.

Atualmente 80 instituições de ensino médico estão em funcionamento, distribuídas em praticamente todos os estados brasileiros ${ }^{3}$. Enquanto os cur-

2 Mendes, J. P. V., (1979), Expansão do ensino médico no Brasil e suas repercussões. In: Simpósio sobre ensino médico. Ed. Academia Brasileira de Medicina.

3 Exceto nos estados do Acre, Amapá, Rondônia, Roraima e Tocantins . 
sos de instituições públicas federais tem presença em todas as regiões, as instituições privadas concentram nos estados da região sudeste a maioria de seus cursos.

A curva de crescimento dos diplomados em Medicina mostra uma relativa estabilidade em torno de 7.000 egressos/ano, com ligeira redução nos anos mais recentes.

GRÁFICO 1

Diplomados em Medicina, Brasil, 1973/1989

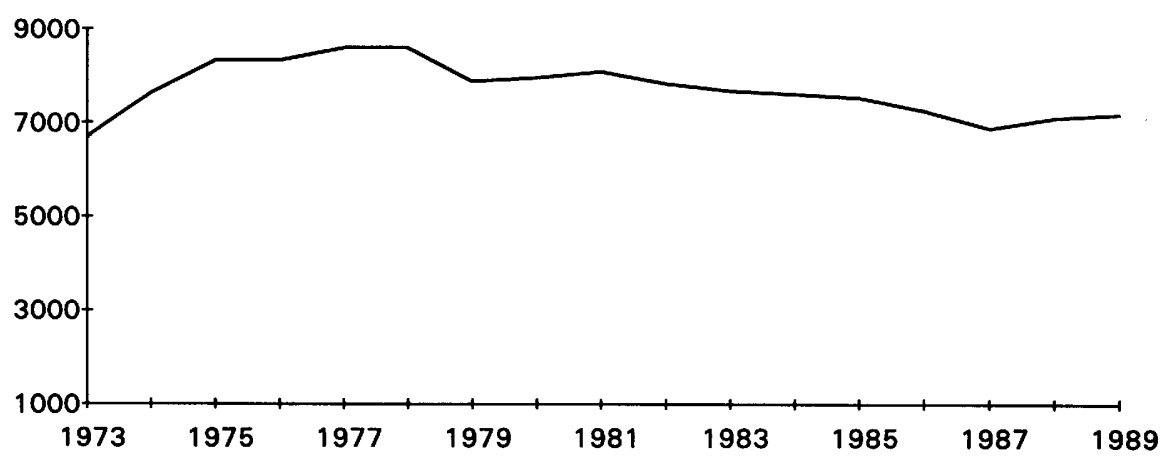

Fonte: SIRH/CGDRI1-SUS/MS.

O financiamento das faculdades públicas é quase que exclusivo de fontes governamentais. No caso de faculdades federais, o Ministério da Educação é responsável pelas atividades financeiras e acadêmicas e a remuneração do staff, igualmente em todo o território nacional, com base numa tabela e critérios de título, tempo parcial ou integral e dedicação exclusiva. No caso de faculdades estaduais, os recursos vêm dos tesouros estaduais.

Quase todos os hospitais universitários pertencentes a faculdades públicas ou privadas são financiados pelo setor público, através principalmente do INAMPS/Ministério da Saúde. As escolas médicas privadas recebem ajuda governamental através do crédito educativo (pagando ajuda aos estudantes menos favorecidos) e a remuneração de serviços prestados por seus hospitais escola. Muitas também obtêm subsídios para suas instalações de fundos de desenvolvimento social. Agências governamentais para o desenvolvimento tecnológico e científico também contribuem através de ajuda à pesquisa e de programas de treinamento de pós-graduação de recursos humanos (CA$\mathrm{PES} / \mathrm{CNPq}$ ). Esta contribuição, no entanto, é aplicada somente a poucas escolas médicas que desenvolvem pesquisa.

Até os anos 40 as escolas médicas brasileiras inspiravam-se no modelo europeu, especialmente o francês, substituída, a partir da $2^{\mathrm{a}}$ Guerra Mundial, 
pela medicina americana, que passou a exercer uma grande influência. A educação médica no Brasil ainda mantém, no entanto, um vínculo com a tradição das escolas francesas, pois as escolas médicas, em geral, não incorporaram experimentos e pesquisa como atividades fundamentais. A influência da medicina americana foi sendo consolidada pela criação da residência médica, hospitais universitários e, posteriormente, pela reforma universitária de 1968, quando o modelo acadêmico inspirado na Reforma Flexner foi definitivamente implantado, com a divisão do curso em ciclo básico e profissional.

O Conselho Federal de Educação, em 1969, através de uma resolução, estabeleceu o currículo mínimo para os cursos médicos e sua duração. Essa resolução estabelece o conteúdo das matérias profissionais básicas a serem organizadas em disciplinas e divididas no currículo de acordo com cada instituição (pública ou privada). O curso deve incluir a teoria básica e experiências práticas relacionadas com as disciplinas, esperando-se que os estudantes trabalhem em centros de saúde, ambulatórios e hospitais-escola. $O$ internato é obrigatório, sob supervisão de staff, por um período mínimo de dois semestres. O curso médico deve alcançar 4.500 horas e durar no mínimo cinco e, no máximo, nove anos.

Apesar da flexibilidade, dada pela resolução, em estabelecer diferentes programas, o currículo da maioria das escolas médicas estão organizadas de maneira rígida e uniforme. sil $^{4}$ :

As características a seguir compõem o típico currículo médico no Bra-

- estrutura curricular inflexível com poucas disciplinas opcionais;

- metodologia de ensino baseada na transmissão do conhecimento, onde é importante a memorização da informação e avaliação feita através de exames teóricos;

- entrada tardia de estudantes nos serviços de saúde, com separação clara entre os ciclos básico e clínico. O ciclo básico com duração de aproximadamente cinco semestres é essencialmente teórico e dado por professores que não trabalham normalmente na clínica. O ciclo profissional consiste de disciplinas que correspondem às especialidades clínicas e cirúrgicas e as "chamadas" áreas básicas (Medicina Interna, Pediatria, Cirurgia e Gineco-Obstetrícia). O internato, parte obrigatória do ciclo profissional, pode ser feito em rodízio nas quatro áreas básicas citadas;

- prática intra-hospitalar, onde o ciclo clínico é predominantemente desenvolvido, contribuindo assim para um maior direcionamento à medicina individual e curativa, à especialização precoce do estudante e favorecendo ainda os procedimentos diagnósticos e terapêuticos sofisticados;

4 Ribeiro, E. C. e Santini, L. A. Medical Education in Brazil, Rio de Janeiro, 1992. (Mimeo) 
- fraca formação científica do estudante, resultado da separação entre ensino e pesquisa, bem como da pouca ênfase no uso de instrumentos como a epidemiologia;

- ênfase no modelo biomédico, onde a doença é reduzida a uma expressão anatomopatológica, o corpo humano concebido como uma máquina composta de órgãos e sistemas e objeto da intervenção médica. $O$ impacto da tecnologia na atenção médica enfraqueceu o papel da relação médico-paciente e da ética na formação.

\section{Condições de Ingresso}

O acesso à escola médica é o mesmo dos demais cursos de nível superior, ou seja: exames de seleção, públicos, para os estudantes que completaram o segundo grau. Os critérios para a admissão são definidos por cada instituição, havendo no entanto uma tendência a associações para a realização dos exames, diante do grande número de candidatos. A relação candidato / vaga tem se mantido bastante alta nesses últimos anos.

\section{TABELA 3}

Distribuição do Número de Vagas e Candidatos aos Exames de Seleção para os Cursos de Medicina, 1986/1990

\begin{tabular}{cccc}
\hline Ano & Vagas & Candidatos & $\begin{array}{c}\text { Relação } \\
\text { candidato/vaga }\end{array}$ \\
\hline 86 & 7.667 & 119.256 & 15,55 \\
87 & 7.707 & 141.751 & 18,39 \\
88 & 7.594 & 141.618 & 18,65 \\
89 & 7.649 & 140.874 & 18,42 \\
90 & 7.804 & 150.003 & 19,22 \\
\hline
\end{tabular}

Fonte: SIRH/CGDRH-SUS/MS.

O Ministério da Educação é o órgão encarregado de acompanhar e avaliar a qualidade das instituições de ensino em saúde, através de suas estruturas como a Secretaria de Ensino Superior. Esse controle, no entanto, tem sido, em geral, apenas normativo e cartorial. Recentemente o Conselho Nacional de Saúde criou uma Comissão Interinstitucional Nacional de Avaliação do Ensino Médico (CINAEM). Essa comissão realizou uma primeira avaliação utilizando um questionário de auto-resposta baseado em material da OPAS. ${ }^{5,6}$

5 Picini, R. X. et al. Avaliação do ensino médico no Brasil: relatório da $1^{\text {* }}$ fase. $R$. Bras. Educ. Méd., R.J., 16(1/3):37-52, jan/dez, 1992.

6 Gonçalves, E. L. Perfil da escola médica brasileira em 1991. Rev. Hosp. Clin. Fac. Med. S. Paulo 47(4), 1992. 
Diante das pressões dos organismos representativos dos médicos e ainda de algumas instituições universitárias, a criação de novos cursos na área de saúde foi disciplinada pelo Decreto 98.377 de 08/11/89, que a par de estabelecer novos procedimentos, incorporou a participação do Conselho Nacional de Saúde ao lado do Conselho Federal de Educação.

\section{- Pós-Graduação}

Além da pós-graduação stricto sensu, como o mestrado e o doutorado, a área médica desenvolveu fortemente os cursos de especialização e a residência médica (lato sensu).

\section{Especialidades Médicas/Residência Médica}

Responsável pela formação da maior parte dos especialistas, a Residência Médica foi introduzida no Brasil entre os anos de 1945 e 1947 na FM-USP e no HSE/RJ. Oficializada em 1977 pelo Decreto $n^{2} 80.281$, de $5 / 9 / 77$, constitui-se como "modalidade de ensino de pós-graduação destinada a médicos sob a forma de especialização, caracterizada por treinamento em serviço, em regime de dedicação exclusiva ${ }^{7}$, funcionando em instituições de saúde, universitárias ou não, sob a orientação de profissionais médicos de elevada qualificação ética e profissional".

Em decorrência dessa legislação foi criada a Comissão Nacional de Residência Médica que, a partir da definição acima dedicou-se a estabelecer normas, requisitos e critérios mínimos para o credenciamento dos programas de Clínica Médica, Cirurgia Geral, Medicina Preventiva e Social, Obstetrícia e Ginecologia e Pediatria, consideradas áreas preferenciais e que até hoje orientam o desenvolvimento dos programas ${ }^{8}$.

Motivo de alguns movimentos e mesmo greves, a filiação do médicoresidente ao sistema da previdência social foi regulamentado em 1987, assegurado ainda os direitos decorrentes de acidentes do trabalho, licença-gestação e outros benefícios. Em 1990 nova lei modifica o valor da bolsa para o médico-residente para $75 \%$ dos vencimentos do médico nível $V$, do Ministério da Educação, acrescido de $100 \%$ por regime especial de treinamento, representando, atualmente, US $\$ 300$ mensais.

Como o processo de registro do diploma é feito centralizadamente na CNRM, pelos programas credenciados, pode-se observar a tendência de crescimento no número de especialistas formados anualmente, com picos acentuados em 1985 e 1988.

7 Modificada por legislação posterior.

8 Gualberto, L. D. Residência Médica no Brasil. Bras. Med. 30 Sup.(1):19:21, jan-mar, 1993. 


\section{GRÁFICO 2}

Médicos-Residentes Registrados na CNRM, 1981/1992

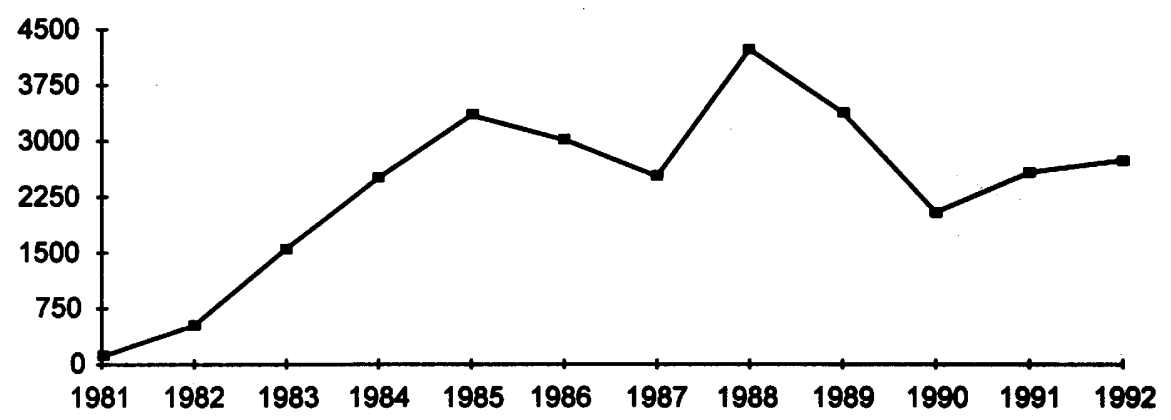

Fonte: CNRM.

Os programas que registraram mais especialistas, nesse período, foram, respectivamente, Pediatria, Cirurgia Geral, Clinica Médica, Gineco-Obstetrícia e Anestesiologia.

\section{GRÁFICO 3}

Evolução dos Médicos-Residentes Registrados na CNRM, por Especialidade, 1981/1992

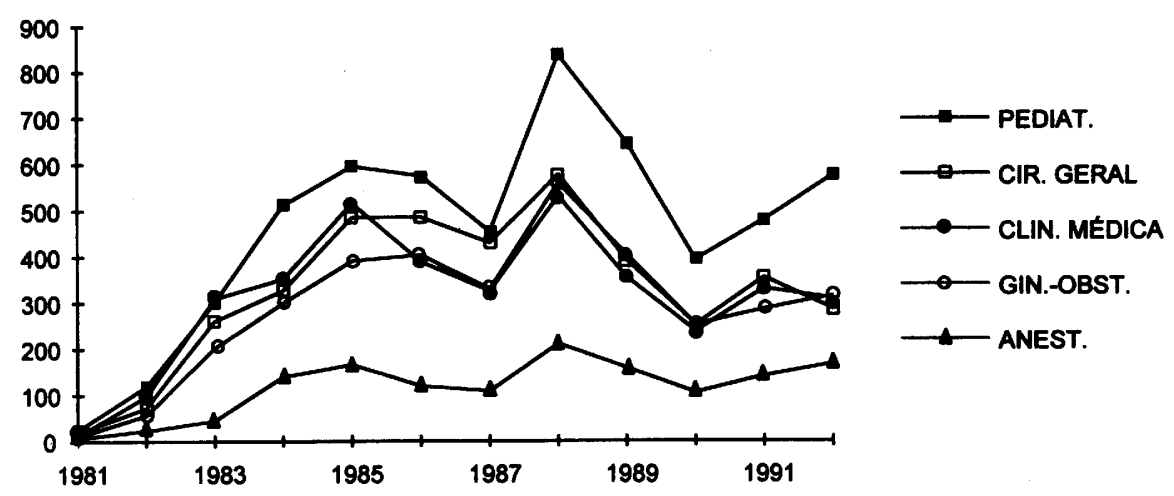

Fonte: CNRM.

No ano de 1992 foram oferecidas 4.889 vagas para ingresso nos programas de residência médica, nas 48 especialidades oferecidas por todas as instituições autorizadas pela CNRM. Essas vagas se concentram na região sudeste, destacando-se o Ministério da Educação e a FUNDAP/SP como as instituições com maior número de residentes e portanto como maiores 
financiadores. Estima-se que existam 120.000 especialistas em todo o país (um pouco mais da metade dos médicos registrados ativos) ${ }^{9}$.

As especialidades reconhecidas pelo Conselho Federal de Medicina, através da Resolução 1.295 de 9.6.1989, para efeito de registro de qualificação de especialista, são as seguintes: administração hospitalar, alergia e imunologia, anestesiologia, angiologia, broncoesofagologia, cancerologia, cardiologia, cirurgia da cabeça e pescoço, cirurgia cardiovascular, cirurgia da mão, cirurgia geral, cirurgia pediátrica, cirurgia plástica, cirurgia torácica, cirurgia vascular, citopatologia, dermatologia, infectologia, eletroencefalografia, endocrinologia e metabologia, fisiatria, foniatria, gastroenterologia, genética clínica, hansenologia, hematologia, homeopatia, medicina geral comunitária, medicina legal, medicina nuclear, medicina sanitária, medicina do trabalho, nefrologia, neurologia pediátrica, neurocirurgia, neurofisiologia clínica, neurologia, nutrologia, obstetrícia, oftalmologia, ortopedia e traumatologia, otorrinolaringologia, patologia, patologia clínica, pediatria, pneumologia, proctologia, psiquiatria, radiologia, radioterapia, reumatologia, sexologia, tisiologia e urologia. Além dessas, estão sendo desenvolvidos programas de especialização em informática médica e medicina do adolescente.

\section{Exercício Profissional}

\section{- Requisitos habilitantes/Controle deontológico}

A legislação brasileira estipula que as escolas médicas, uma vez autorizadas a funcionar, estão qualificadas a fornecer o diploma (certificado) aos alunos que completarem o curso. Para exercer sua profissão, o recém-graduado deve registrar seu diploma no Conselho Regional de Medicina. Esse registro só pode ser feito em dois estados simultaneamente.

Esses Conselhos, organizados em cada estado e nacionalmente, constituem uma autarquia, dotados, cada um deles, de personalidade jurídica de direito público numa autarquia, subordinada ao Ministério do Trabalho (Conselho Federal de Medicina), responsabilizando-se pelo controle dos aspectos éticos da profissão, examinando e julgando os processos de infração ao Código de Ética, podendo inclusive cassar o registro profissional.

Após um amplo processo de debates que culminou numa Conferência Nacional, o CFM, através da Resolução 1246 de 8/1/1988, aprovou um novo Código de Ética, substituindo as normas anteriores de 1965 e 1984.

O piso salarial dos médicos no setor privado está fixado na Lei $3999 / 61$, em três salários-mínimos (menos de US\$250), para uma duração normal de trabalho de 2 a 4 horas diárias ( 24 horas semanais). A revogação dessa lei, superada pela nova constituição e pela proibição de vinculação do

9 Machado, M. H. et al. Estudo exploratório sobre especialidades médicas no Brasil, ENSP/FIOCRUZ/CCDRH-SUS/MS, Rio de Janeiro, 1993. 
piso salarial ao salário-mínimo, é motivo de movimento e mobilização das entidades médicas que estão apoiando o projeto de lei $n^{\circ}$ 1270/91 (chamada de "lei do médico"), em tramitação na Câmara dos Deputados e que fixa como novo piso salarial um valor aproximado de US\$1,000.

Como elemento de comparação com essa proposta de piso salarial, a Federação Nacional dos Médicos levantou alguns salários no nível inicial de alguns órgãos do setor público, mostrando a enorme e dramática defasagem salarial existente.

\section{TABELA 4}

Salário Inicial da Carreira de Médico em Alguns Órgãos Públicos, Brasil, 1993

\begin{tabular}{lcr}
\hline Órgãos Públicos & Cr\$ (março/93) & US\$ \\
\hline SES/MG & $1.410 .000,00$ & 55 \\
IPSEMG & $3.476 .000,00$ & 135 \\
SMS/Rio de Janeiro & $3.500 .000,00$ & 136 \\
SES/RN & $4.439 .000,00$ & 173 \\
SMS/Porto Alegre & $4.759 .000,00$ & 185 \\
SMS/São Paulo & $5.685 .000,00$ & 222 \\
SES/CO & $6.698 .000,00$ & 261 \\
\hline
\end{tabular}

Fonte: FENAM.

A estrutura sindical dos médicos é constituída por 45 entidades sindicais, agrupadas na Federação Nacional dos Médicos. Esses sindicatos contam com 69.000 associados, representando aproximadamente $30 \%$ dos médicos em atividade. Dentre esses sindicatos 20 representam bases estaduais e 25 , bases municipais.

\section{- Registro de estrangeiros}

Os médicos estrangeiros que estejam no país para estudo, sob supervisão e orientação, não estão obrigados ao registro nos Conselhos Regionais de Medicina, não estando assim, "autorizado ou habilitado ao exercício regular da profissão", nos termos da Resolução 806 de 29.07.1977, do CFM. Idêntico tratamento é dado para os médicos estrangeiros convidados para atos médicos de demonstração didática, por universidades, órgãos oficiais ou entidades científicas.

No caso do médico estrangeiro asilado político ou territorial, admite-se, com base na Resolução 1.244 de 8.8.1977, sua inscrição nos Conselhos Regionais de Medicina e o exercício regular da profissão, desde que comprova- 
da a capacidade profissional, pelos órgãos de ensino, e a condição do asilo, pelo Ministério da Justiça.

Os diplomas ou certificados expedidos por escola médica no exterior necessitam ser revalidados por instituição de ensino credenciada pelo Ministério da Educação. Este procedimento se aplica aos estrangeiros ou brasileiros, segundo Resolução do Conselho Federal de Educação.

\section{Oferta/Demanda}

Os médicos em atividade, em todo o Brasil, somam 208.966, com uma participação feminina de apenas $29 \%$. O Sudeste tem mais da metade de todos os médicos em atividade $(61,5 \%)$, ao passo que a Região Amazônica e todo o Norte do país é extremamente carente de profissionais. O Norte e o Nordeste têm três vezes menos médicos, por 10.000 habitantes, que o Sudeste.

\section{TABELA 5}

Médicos Cadastrados nos Conselhos Regionais de Medicina, em Atividade, por Região, Brasil, 1993

\begin{tabular}{lrrrrrrr}
\hline Regiões & Homens & $\%$ & Mulheres & $\%$ & Total & $\%$ & $\begin{array}{r}\text { Total/ } \\
110.000 \\
\text { hab. }\end{array}$ \\
\hline Norte & 4.102 & 67,48 & 1.977 & 32,52 & 6.079 & 2,91 & 6,23 \\
Nordeste & 21.603 & 63,95 & 12.179 & 36,05 & 33.782 & 16,17 & 7,95 \\
Sul & 21.285 & 76,56 & 6.515 & 23,44 & 27.800 & 13,30 & 15,43 \\
Sudeste & 91.766 & 71,36 & 36.832 & 28,64 & 128.598 & 61,54 & 20,52 \\
Centro-Oeste & 9.358 & 73,64 & 3.349 & 26,36 & 12.707 & 6,08 & 13,50 \\
\hline Total & 148.114 & 70,88 & 60.852 & 29,12 & 208.966 & 100,00 & 14,68 \\
\hline
\end{tabular}

Fonte: CFM.

O crescimento dos empregos dos médicos, no período $81 / 87$, foi de $34,39 \%$ em todo o país. A menor taxa, $7,45 \%$, foi registrada pela região Sudeste.

Uma das tendências verificadas no período $81 / 87$ foi o crescimento do emprego no setor público. O número de postos de trabalho médico teve um crescimento de $16,56 \%$. Essa participação do setor público no mercado de trabalho ainda é na esfera federal, porem com progressivo aumento relativo dos setores estaduais e municipais ${ }^{16}$.

10 Nogueira, R. P. Emprego em saúde por natureza jurídico-administrativa dos estabelecimentos, 1981/1987. In: Boletim Informativo RH-SUS, 1, ago, CGDRH/SUS, Min. Saúde, Brasília, 1991. 
TABELA 6

Total de Postos de Trabalho Médicos, em Estabelecimentos de Saúde, Segundo Regiões, Brasil, 1981/1987

\begin{tabular}{lrrr}
\hline Regiões & 1981 & 1987 & $\begin{array}{c}\text { Variação } \\
\%\end{array}$ \\
\hline Norte & 3.541 & 5.485 & 55 \\
Nordeste & 27.030 & 40.054 & 48 \\
Sul & 22.789 & 24.487 & 7 \\
Sudeste & 94.102 & 123.416 & 31 \\
Centro - & 8.420 & 12.937 & 54 \\
Oeste & & & \\
\hline Brasil & 155.882 & 206.379 & 32 \\
\hline
\end{tabular}

Fonte: AMS/BBGE.

\section{GRÁFICO 4}

Evolução do Total de Postos de Trabalho para Médicos, por Regiōes, Brasil, $1981 / 1987$

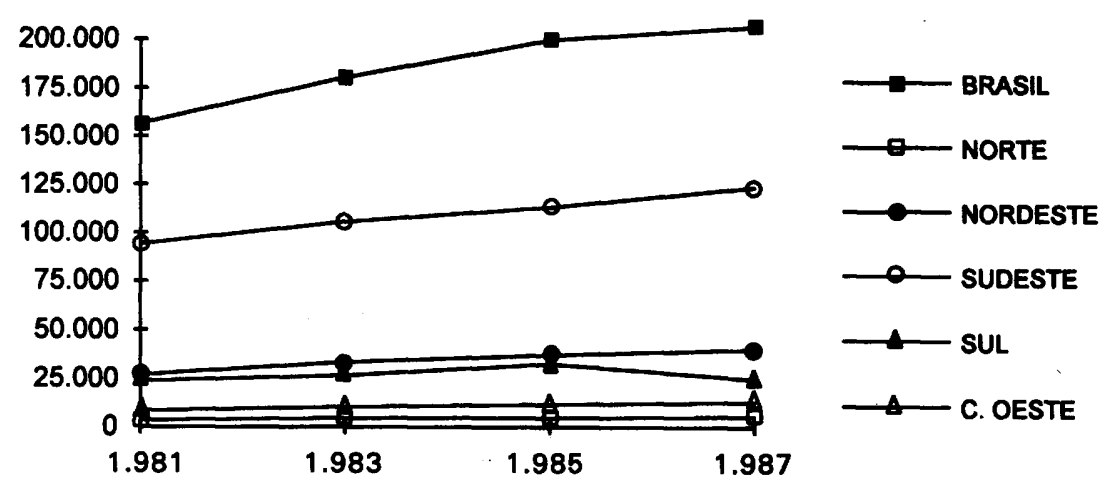

Fonte: AMS/IBGE. 


\section{TABELA 7}

Participação Percentual dos Empregos de Médico no Setor Público, por Regiões, Brasil, 1981/1987

\begin{tabular}{lrrr}
\hline Regiões & 1981 & 1987 & $\begin{array}{c}\text { Variação } \\
\%\end{array}$ \\
\hline Norte & 1,30 & 1,80 & 38,46 \\
Nordeste & 10,10 & 12,30 & 21,78 \\
Sul & 25,80 & 29,40 & 13,95 \\
Sudeste & 5,80 & 6,40 & 10,34 \\
Centro & 2,90 & 3,60 & 24,14 \\
Oeste & & & \\
\hline Total & 45,90 & 53,50 & 16,56 \\
\hline
\end{tabular}

Fonte: AMS/IBGE.

\section{GRÁFICO 5}

Participação Percentual dos três Níveis do Setor Público em Relação ao To. tal de Empregos de Médico, Brasil, 1981/1987

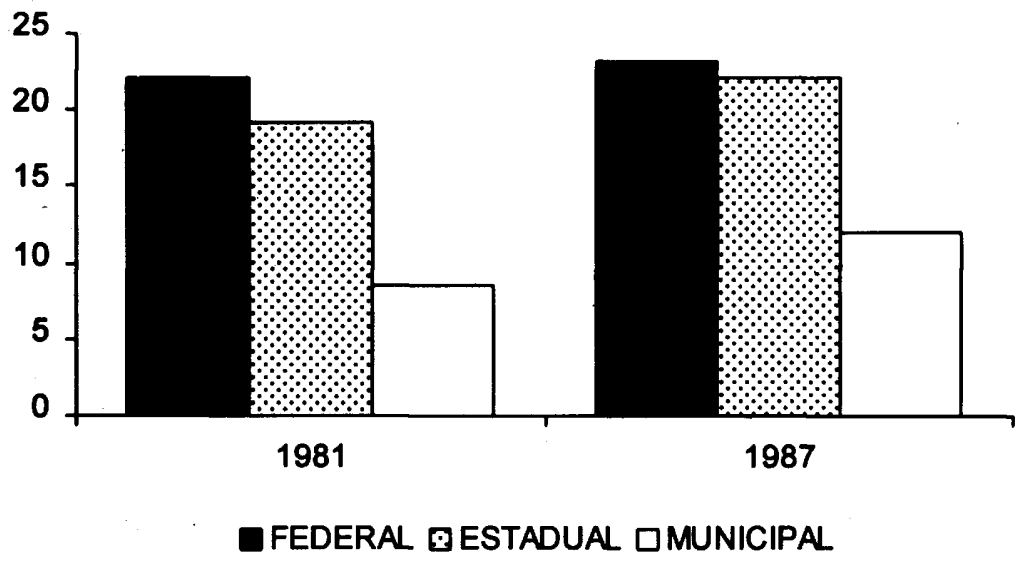

Fonte: AMS/IBGE 


\section{PESSOAL DE ENFERMAGEM}

\section{Formação}

As categorias de Enfermagem são estruturadas verticalmente pelos enfermeiros (formados em cursos de graduação de nível superior), técnicos de enfermagem (formados em cursos de nível médio de $2^{2}$ grau), auxiliares de enfermagem (formados em cursos de $1^{\circ}$ e $2^{\circ}$ grau) e parteiras, conforme definição da Lei 7.498 de 26.06 .86 e do Decreto 94.406 de 08.06 .87 , que "dispõe sobre a regulamentação do exercício da enfermagem". A força de trabatho em enfermagem está ainda constituída pelo atendente, sem preparo formal, submetido ou não a programas de treinamento, englobando todas as demais categorias de pessoal auxiliar não regulamentadas pela legislação.

\section{- Graduação}

A enfermagem moderna no Brasil teve seu momento inicial com a criação, em 1923, da Escola de Enfermagem do Departamento Nacional de Saúde Pública (hoje Escola Ana Néri, da UFRI), com recursos da Fundação Rockefeller e enfermeiras americanas como fundadoras ${ }^{11}$.

O número de cursos de enfermeiros, atualmente, é de 102, em todo o Brasil. As entidades privadas são responsáveis por 45 deles, cuja grande concentração está na Região Sudeste.

A distribuição geográfica dos cursos mostra uma grande concentração na região Sudeste.

\section{TABELA 8}

Distribuição dos Cursos de Enfermagem Segundo a Dependência Administrativa da Entidade Mantenedora, Brasil, 1990

\begin{tabular}{lccccccc}
\hline $\begin{array}{l}\text { Dependência } \\
\text { Administrativa }\end{array}$ & Norte & Nordeste & Sudeste & Sul & C. Oeste & Brasil & $\%$ \\
\hline Federal & 5 & 9 & 10 & 6 & 3 & 33 & 32,1 \\
Estadual & 1 & 8 & 6 & 4 & 0 & 19 & 18,1 \\
Municipal & 0 & 0 & 4 & 1 & 0 & 5 & 4,9 \\
Privada & 1 & 5 & 28 & 10 & 1 & 45 & 44,1 \\
\hline Total & 7 & 22 & 48 & 21 & 4 & 102 & 100,0 \\
\hline
\end{tabular}

Fonte SIRH/CCDRH-SUS/MS.

11 Vieira, T. T.; SiLVA, A. L. C. Recursos Humanos na área de enfermagem: adequação da formação à utilização. Rio de Janeiro, 1991. (Mimeo) 


\section{Condições de Ingresso}

Os mecanismos de ingresso são os mesmos para todos os cursos de nível superior, ou seja, provas seletivas públicas, para as quais concorrem os estudantes concluintes do $2^{9}$ grau.

No período $87 / 90$ os cursos de enfermeiro tiveram um incremento no número de vagas, associado, no entanto, à pequena, mas constante, redução na relação entre os candidatos cuja $1^{a}$ opção foi esta, e o número de vagas ofertadas.

\section{TABELA 9}

Distribuição do Número de Candidatos e Vagas Oferecidas pelos Cursos de Enfermagem, Brasil, 1986/1990

\begin{tabular}{cccc}
\hline Ano & Candidatos & Vagas & Relação \\
\hline 86 & 23633 & 6560 & 3.6 \\
87 & 25956 & 6807 & 3.8 \\
88 & 23686 & 6847 & 3.4 \\
89 & 21856 & 6885 & 3.1 \\
90 & 24432 & 7564 & 3.2 \\
\hline
\end{tabular}

Fonte: SIRH/CGDRH-SUS/MS.

Um dado bastante preocupante é o aumento do número de alunos afastados durante o curso, especialmente por abandono.

\section{TABELA 10}

Distribuição do Número de Alunos Afastados dos Cursos de Enfermagem Segundo as Regiões, Brasil, 1986/1990

\begin{tabular}{lcccccc}
\hline Ano & Norte & Nordeste & Sudeste & Sul & C. Oeste & Brasil \\
\hline 1986 & 35 & 351 & 491 & 510 & 59 & 1.446 \\
1987 & 14 & 583 & 676 & 336 & 40 & 1.649 \\
1988 & 107 & 901 & 1421 & 833 & 191 & 3.453 \\
1989 & 78 & 1167 & 1297 & 738 & 90 & 3.379 \\
1990 & 53 & 1490 & 1097 & 925 & 227 & 3.792 \\
\hline
\end{tabular}

Fonte: SIRH/CGDRH-SUS/MS. 
O conteúdo mínimo dos cursos de enfermagem, bem como sua duração, estão definidos pelo Conselho Federal de Educação através do Parecer 163/72 e Resolução 04/72. Constituindo-se de três partes - pré-profissional, tronco profissional e habilitações, o curso de enfermagem deve ter carga horária mínima de 2.500 a 3.000 horas, integralizados no período de 4 a 6 anos letivos.

As habilitações possíveis, segundo o parecer, são a enfermagem médico-cirúrgica, a enfermagem obstétrica ou obstetrícia e a enfermagem de saúde pública, além da licenciatura facultativa após o término do tronco profissional.

A estrutura curricular vigente acha-se sob severa crítica dos órgãos representativos da enfermagem que, através da Associação Brasileira de Enfermagem, elaboraram nova proposta para o currículo mínimo ${ }^{12}$.

A mesma influência sofrida pela escola médica repercutiu na formação dos enfermeiros. Assim, a ênfase na atenção individual-curativa e a pouca utilização da epidemiologia tem sido a tônica dos cursos. Outro ponto a relevar é a massiva utilização de bibliografia de origem americana e a quase ausência de material nacional.

Dados de 1983 revelam a existência de 115 cursos de Técnicos de Enfermagem e 145 de Auxiliar de Enfermagem. Grande parte desses cursos estavam localizados na Região Sudeste e eram de natureza privada.

\section{- Pós-Graduação}

O número de cursos de pós-graduação stricto sensu voltados especificamente para a área de enfermagem, no país, ainda é reduzido. Até 1989 a CAPES tinha credenciado 11 cursos, sendo quatro de doutorado. Outros dez cursos (cinco de doutorado) estão em avaliação, neste momento.

\section{Exercício Profissional}

\section{- Requisitos habilitantes/controle deontológico}

"A enfermagem e suas atividades auxiliares somente podem ser exercidas por pessoas legalmente habilitadas e inscritas no Conselho Regional de Enfermagem com jurisdição na área onde ocorre o exercício." Através desse artigo da Lei 7.498/86 está fixada a obrigação de inscrição no COREN para o exercício das atividades de enfermagem.

O código de deontologia da enfermagem foi aprovado pela Resolução 9 de 4.10.1975, pelo Conselho Federal de Enfermagem.

A organização sindical dos enfermeiros é recente. $O$ primeiro sindicato de enfermeiros, no Brasil, foi fundado apenas em 1976, culminando um pro-

12 Associação Brasileira de Enfermagem. Proposta de novo currículo mínimo para o curso superior de enfermagem, Brasília, 1991. (Mimeo). 
cesso que teve no ano de 1961 uma associação profissional de enfermagem. A Federação Nacional dos Enfermeiros foi criada somente em 1987.

Diferentemente de outras categorias profissionais, os enfermeiros não têm uma lei específica regulando o piso salarial. Projetos nesse sentido têm sido propostos na Câmara de Deputados sem, no entanto, alcançar êxito.

\section{Oferta/Demanda}

A distribuição dos profissionais de enfermagem nas diversas regiões do país é bastante irregular, com grande concentração no Sudeste, que apresenta uma relação por 10.0000 habitantes três vezes superior às Regiões Norte e Nordeste.

\section{TABELA 11}

Distribuição dos Profissionais de Enfermagem Registrados nos COREN, por Regiões, Brasil, 1992

\begin{tabular}{lrrrrrr}
\hline Regiões & Enfermeiros & Técnicos & Auxiliares & Parteiras & Total & $\begin{array}{c}\text { Total/ } \\
10.000 \\
\text { hab. }\end{array}$ \\
\hline Norte & 2.477 & 997 & 6.438 & 21 & 9.933 & 10,18 \\
Nordeste & 11.794 & 5.042 & 21.070 & 25 & 37.931 & 8,93 \\
Sul & 8.351 & 4.030 & 24.027 & 0 & 36.408 & 20,21 \\
Sudeste & 31.251 & 28.507 & 103.181 & 3 & 162.942 & 26,00 \\
C. Oeste & 3.174 & 3.174 & 8.644 & 0 & 17.172 & 18,24 \\
\hline Brasil & 57.047 & 42.930 & 163.360 & 49 & 264.386 & 18,58 \\
\hline
\end{tabular}

Fonte: COFEN.

Os dados do COFEN não contemplam uma parte importante da força de trabalho em enfermagem, que são os "atendentes" que com variadas denominações chegam a representar $60 \%$ do pessoal de enfermagem. Não registrados no Conselho, obrigados a se regularizar no prazo de dez anos (Lei $7.498 / 86)$, representam um problema e um desafio para os órgãos e instituições de saúde e educação.

O periodo $81 / 87$ trouxe um crescimento de $80 \%$ no número de postos de trabalho de enfermeiros, em todo o Brasil. Apesar do nivel federal ter aumentado, é nos segmentos estadual e municipal que a ampliação dos postos de trabalho no setor público ocorre com maior intensidade. A tendência, assim, é que essa alteração tenha se acentuado após o período $89 / 90$, ante o processo de ampliação das rendas municipais e a transferência de encargos federais na saúde para estados e municípios. 


\section{GRÁFICO 6}

Evolução dos Postos de Trabalho de Enfermeiros, Segundo as Regiões, Brasil, 1981/1987

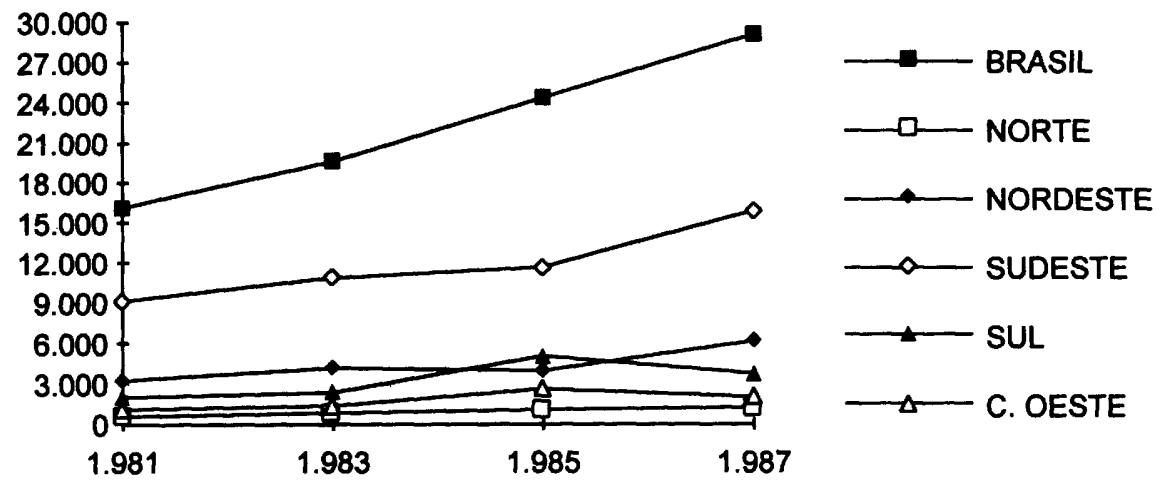

Fonte: AMS/IBGE.

\section{GRÁFICO 7}

Evolução dos Postos de Trabalho para Enfermeiros nos Estabelecimentos de Saúde do Setor Público, Por Nivel, Brasil, 1981/1987

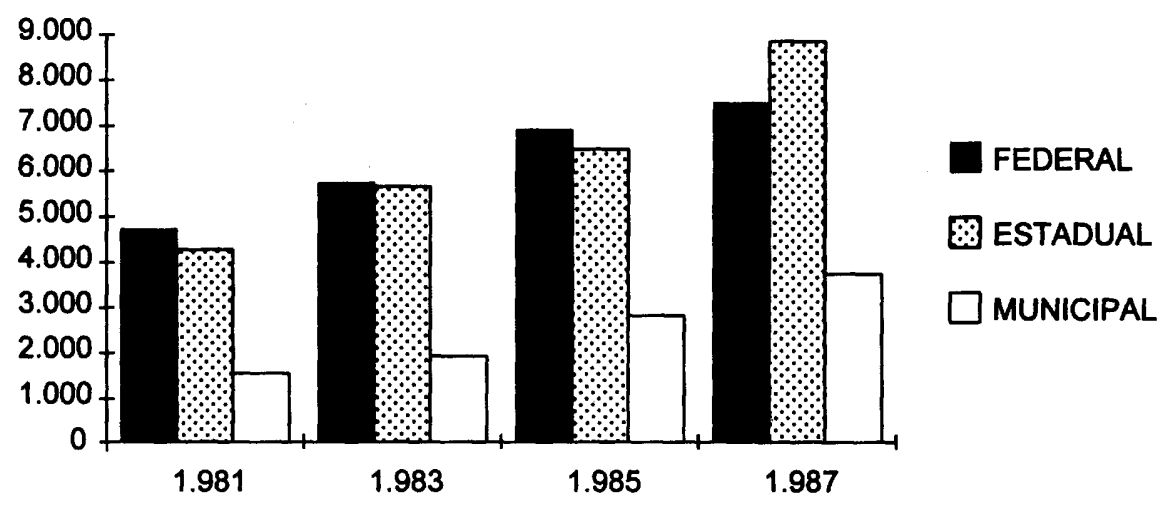

Fonte: AMS/IBCE.

O pessoal de enfermagem, na sua grande maioria, é empregado e assalariado, sendo o contingente de autônomos insignificante. 


\section{ODONTÓlOGOS}

\section{Formação}

\section{- Graduação}

Considerado como nível superior em 1879, o primeiro curso de Odontologia foi em efetivamente reconhecido em 1884, anexo à Faculdade de Medicina do Rio de Janeiro. O ritmo e o processo de criação e instalação de novos cursos de Odontologia não parecem ter se associado a nenhum fator demográfico ou de política educacional, mas aos fatores de natureza de politica local, ou econômica.

TABELA 12

Distribuição dos Cursos de Odontologia, Segundo

o Período de Criação, Brasil, 1992

\begin{tabular}{lc}
\hline Periodo & $N^{*}$ de Escolas \\
\hline Até 1900 & 4 \\
De 1901 a 1950 & 15 \\
De 1950 a 1964 & 17 \\
De 1965 a 1971 & 9 \\
De 1972 a 1992 & 33 \\
\hline
\end{tabular}

Fonte: MEC.

Os 81 cursos de Odontologia em funcionamento distribuem-se desigualmente no país, com marcada concentração nos estados da região Sudeste, especialmente por parte das instituições privadas.

\section{TABELA 13}

Distribuição dos Cursos de Odontologia Segundo a Dependência Administrativa da Instituição Mantenedora, Brasil, 1990

\begin{tabular}{lccccccr}
\hline $\begin{array}{l}\text { Dependência } \\
\text { Administrativa }\end{array}$ & Norte & Nordeste & Sudeste & Sul & C. Oeste & Brasil & $\%$ \\
\hline Federal & 2 & 9 & 8 & 5 & 3 & 27 & 33,3 \\
Estadual & 0 & 3 & 9 & 3 & 0 & 15 & 18,5 \\
Municipal & 0 & 0 & 3 & 1 & 0 & 4 & 4,9 \\
Privada & 0 & 1 & 26 & 5 & 6 & 35 & 43,3 \\
\hline Total & 2 & 13 & 46 & 14 & 6 & 81 & 100,0 \\
\hline
\end{tabular}

Fonte: SIRH/CGDRH-SUS/MS. 
Considerando-se que, desde 1987, o número de candidatos ao curso de Odontologia tem se mantido em torno de 100.000 , a relação candidato/vaga melhorou um pouco, pois as vagas aumentaram $12,5 \%$ no período.

\section{TABELA 14}

Distribuição do Número de Candidatos e Vagas Oferecidas pelos Cursos de Odontologia, Brasil, 1986/1990

\begin{tabular}{lrrr}
\hline Ano & Candidatos & Vagas & $\begin{array}{c}\text { Relação } \\
\text { Candidato/Vaga }\end{array}$ \\
\hline 86 & 81.393 & 6.061 & 13,4 \\
87 & 101.855 & 6.121 & 16,6 \\
88 & 108.601 & 6.616 & 16,4 \\
89 & 99.149 & 6.481 & 15,2 \\
90 & 103.588 & 6.947 & 14,9 \\
\hline
\end{tabular}

Fonte: SIRH/CGDRH-SUS/MS.

O currículo mínimo, segundo o Parecer $840 / 70$ do Conselho Federal de Educação, estabelece em 3.600 horas a carga horária mínima, integralizadas no periodo de 8 a 18 semestres letivos. A estrutura dos cursos é praticamente a mesma em todas as instituições, constando de dois ciclos: básico (carga horária média de 1200 horas) e profissional (carga horária média de 2.400 horas). O ciclo básico, em geral, é comum com outros cursos da área de ciências da saúde. Um estudo ${ }^{13}$ mostrou que mais de $80 \%$ do ciclo profissional é composto pelas "disciplinas relacionadas às patogenias e suas especificidades como Dentística, Cirurgia, Endodontia, Diagnóstico Oral, Ortodontia, Radiologia etc. ".

\section{- Pós-Graduação}

O Conselho Federal de Odontologia, através da Resolução 181 de 06.06.1992, disciplinou a especialização em Odontologia, adotando as decisões da I Assembléia Nacional de Especialidades Odontológicas, realizada em abril de 1992.

Os requisitos para o registro e inscrição, como especialista, do cirurgião-dentista são, assim, os seguintes:

- título de livre docente, doutorado ou mestrado, na área da especialidade;

13 Melo, M. L. T. Os cursos de Odontologia e a realidade nacional brasileira: contribuição para um estudo. Tese de mestrado, UFF, Niterói, 1981. 
- certificado de curso de especialização em Odontologia ministrados por instituições de ensino, escola de saúde pública ou militar ou entidade de classe, respeitadas as normas do CFE e do próprio CFO.

As especialidades admitidas, em número de 14, são as seguintes: cirurgia e traumatologia buco-maxilo-faciais; dentística restauradora; endodontia; odontologia legal; odontologia em saúde coletiva; odontopediatria; ortodontia; patologia bucal; periodontia; prótese buco-maxilo-facial; prótese dentária; radiologia; implantologia; estomatologia.

Até 1989 a CAPES tinha credenciado 52 cursos de mestrado e doutorado. Atualmente, outros 33 cursos estão sob avaliação. A imensa maioria dos cursos se localizam no Estado de São Paulo.

\section{Exercício Profissional}

- Requisitos habilitantes/Controle deontológico

As atividades profissionais do cirurgião-dentista são reguladas pelas Leis $4.324 / 64$ e 5.081/66, bem como pelo Decreto 68.704/71. Com base nessa legislação, o Conselho Federal de Odontologia estabelece as normas para o exercício profissional pelos cirurgiões-dentistas, incluindo-se os requisitos para o exercício legal das categorias profissionais de nível médio relacionadas: técnicos em prótese dentária, técnicos em higiene dental e atendentes de consultório dentário.

Para o exercício legal das atividades os cirurgiões-dentistas estão obrigados à inscrição nos Conselhos Regionais de Odontologia.

O exercício das atividades de técnico em prótese dentária exige o diploma ou certificado de curso de prótese dentária, em nivel de $2^{\circ}$ grau, conferido por estabelecimento oficial ou reconhecido. No caso de diplomas ou certificados expedidos por instituições estrangeiras, é necessário a revalidação e o registro no Ministério da Educação.

O técnico em higiene dental e o atendente de consultório dentário são habilitações profissionais de $1^{\circ}$ e $2^{\circ}$ graus, regulamentadas pelos Pareceres 540/72 e 460/75 do Conselho Federal de Educação, que também estão sujeitas ao registro nos Conselhos Regionais de Odontologia.

$\mathrm{O}$ código de ética e as normas relativas aos processos ético odontológicos foram recentemente renovadas, em decorrência da I Conferência Nacional de Ética Odontológica, através das Resoluções 179 de 19.12 .1991 e 183 de 01.10.1992, no contexto de um debate bastante amplo sobre a questão da ética nas profissões da saúde.

\section{- Registro de estrangeiros}

Os cirurgiões-dentistas estrangeiros portadores de "visto temporário" ou "registro provisório" poderão, durante sua estadia no Brasil, trabalhar com inscrição profissional provisória. 
No caso dos estrangeiros diplomados no Brasil, no regime de convênio-cultural, as normas são mais restritivas (Resolução 13 de 9.12.1967).

\section{Oferta/Demanda}

Na última década, o crescimento de inscrições de cirurgiões-dentistas nos Conselhos Regionais de Odontologia aumentou $51 \%$ em todo o país. A Região Nordeste teve, relativamente, o menor incremento (44\%) e, ao lado da Região Norte tem quatro a cinco vezes menos profissionais que o Sul e o Sudeste.

\section{TABELA 15}

Distribuição dos Cirurgiões-dentistas Inscritos nos Conselhos Regionais de Odontologia, por Regiões, Brasil, 1981/1992

\begin{tabular}{lrrrr}
\hline Regiões & 1981 & 1992 & Var. \% & $\begin{array}{r}\text { Total 92/ } \\
10.000 \text { hab. }\end{array}$ \\
\hline Norte & 1.336 & 2.850 & $53,1 \%$ & 2,92 \\
Nordeste & 8.976 & 16.049 & $44,0 \%$ & 3,78 \\
Sul & 8.671 & 17.031 & $49,1 \%$ & 9,45 \\
Sudeste & 34.679 & 75.144 & $53,8 \%$ & 11,99 \\
Centro-Oeste & 3.923 & 7.535 & $47,9 \%$ & 8,01 \\
\hline Brasil & 57.585 & 118.609 & $51,4 \%$ & 8,33 \\
\hline
\end{tabular}

Fonte: CFO.

No período $81 / 87$ os postos de trabalho para odontólogos tiveram um aumento de $48 \%$. A Região Norte, com $127 \%$, foi a que mais cresceu, apesar de permanecer com um baixíssimo número de cirurgiões-dentistas.

No setor público, apesar dos estados terem assumido a liderança na quantidade de postos de trabalho para odontólogos, chama a atenção o crescimento do segmento municipal. Nos últimos anos, com a progressiva redução do nivel federal (não-contratação associado às saídas por aposentadoria, principalmente) e a política de "municipalização", deve ter acelerado mais ainda a oferta de empregos pelos municípios. 


\section{GRÁFICO 8}

Evolução dos Postos de Trabalho para Odontólogos, por Região, Brasil, $1981 / 1987$
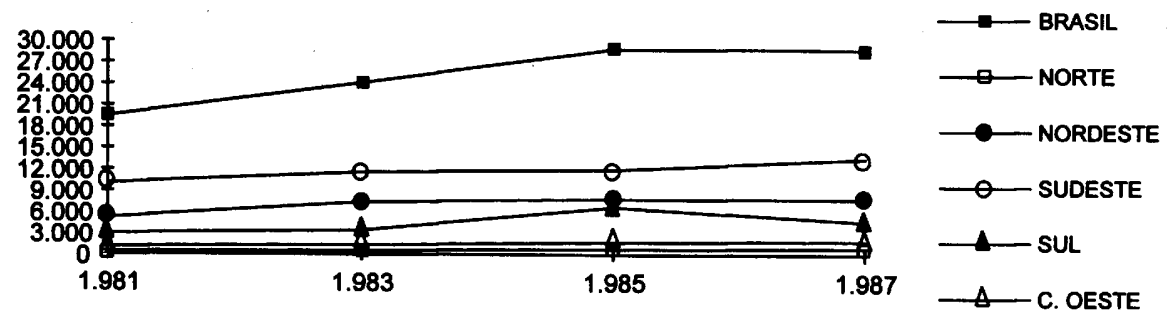

Fonte: AMS/IBGE.

Entre os odontólogos é expressivo o contingente de autônomos, havendo um decréscimo pouco significativo ao longo da década de 70 , de $69.6 \%$ para $54.5 \%$.

\section{GRÁFICO 9}

Evolução dos Postos de Trabalho para Odontólogos nos Estabelecimentos de Saúde do Setor Público, por Nível, Brasil, 1981/1987

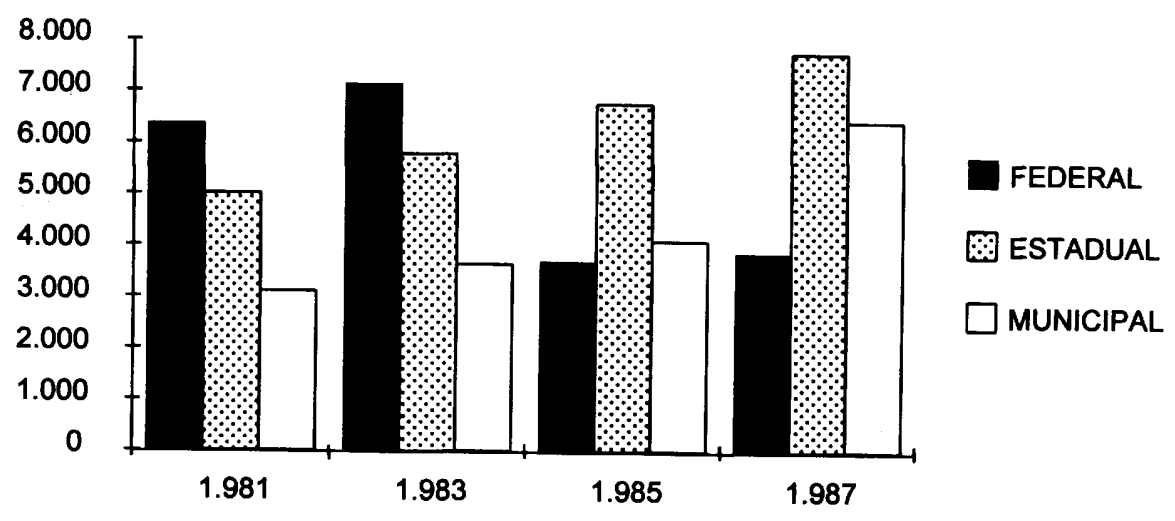

Fonte: AMS/IBGE.

Os profissionais de nivel médio registrados nos Conselhos Regionais de Odontologia alcançam apenas $12 \%$ da força de trabalho em Odontologia, expressando grande debilidade nessa composição. 
TABELA 16

Distribuição das Habilitações Profissionais em Odontologia Inscritos nos CRO, por Regiões, Brasil, 1992

\begin{tabular}{lccc}
\hline Regiões & $\begin{array}{c}\text { Técnico } \\
\text { Prótese Dentária }\end{array}$ & $\begin{array}{c}\text { Técnico Higiene } \\
\text { Dental }\end{array}$ & $\begin{array}{c}\text { Atendente } \\
\text { Consultório } \\
\text { Dentário }\end{array}$ \\
\hline Norte & 170 & 131 & 219 \\
Nordeste & 842 & 154 & 587 \\
Sul & 1371 & 345 & 332 \\
Sudeste & 6407 & 1204 & 3343 \\
Centro Oeste & 527 & 445 & 176 \\
\hline Brasil & 9317 & 2279 & 4657 \\
\hline
\end{tabular}

Fonte: CFo.

\section{OUTRAS PROFISSÕES}

Neste item foram consideradas e incluídas diversas profissões, cada vez mais presentes na composição da força de trabalho dos serviços de saúde. Agrupá-las neste estudo se explica, em parte, pela própria insuficiência de dados para uma análise mais aprofundada. Além disso, em seu conjunto, significam parcela ainda pequena se comparadas com os médicos e pessoal de enfermagem.

Muitas dessas profissões foram criadas ou se estabeleceram como profissões de saúde há poucas décadas. Uma exceção é o curso de farmácia, criado como anexo ao de medicina em 1832.

A medicina veterinária vem ampliando seu espaço técnico e mesmo político nos serviços públicos de saúde, tanto no controle das zoonoses como na vigilância sanitária de alimentos (VISA). Com a municipalização dessas ações, têm sido ampliados os postos de trabalho para medicos veterinários nas Secretarias Municipais de Saúde.

Das profissões mais recentes, a psicologia vem se destacando pelo rápido crescimento do número de profisionais inscritos nos Conselhos, totalizando 79.524 inscrições até 1992. A Região Sudeste concentra a imensa maioria desses profissionais $(74,88 \%)$, numa relação de $9 / 10.000$ habitantes. 


\section{TABELA 17}

Distribuição de Profissionais de Saúde Inscritos nos Conselhos Profissionais, por Regiōes, Brasil, 1992

\begin{tabular}{lrrrrrr}
\hline Profissionais & Norte & Nordeste & Sul & Sudeste & C. Oeste & Brasil \\
\hline Farmácia & 1.435 & 7.805 & 9.429 & 22.341 & 2.927 & 43.937 \\
Fisioterapia & 172 & 2.295 & 2.997 & 14.284 & 419 & 20.167 \\
Terapia Ocupacional & 23 & 37 & 413 & 2.675 & 98 & 3.246 \\
Psicologia & 854 & 7.961 & 8.936 & 57.163 & 4.610 & 79.524 \\
Assistente Social & 2.941 & 11.950 & 5.464 & 34.683 & 3.309 & 58.347 \\
Medicina Veterinária & 843 & 4.835 & 7.862 & 12.520 & 3.022 & 29.082 \\
Nutrição & $\star$ & 3.247 & 2.731 & 9.199 & 713 & $15.890(\#)$ \\
Fonoaudiologia & 60 & 1.014 & 1.317 & $*$ & 29 & $2.420(\#)$ \\
\hline
\end{tabular}

Fonte: $\mathrm{CF}^{\prime}$ ' ( ${ }^{*}$ = sem informação / \# = parcial).

\section{TABELA 18}

Distribuição de Profissionais de Saúde Inscritos nos Conselhos Profissionais, por Regiões, por 10.000 Habitantes, Brasil, 1992

\begin{tabular}{lcccccc}
\hline Profissionais & Norte & Nordeste & Sul & Sudeste & C. Oeste & Brasil \\
\hline Farmácia & 1,30 & 1,80 & 4,20 & 3,50 & 3,10 & 2,99 \\
Fisioterapia & 0,16 & 0,54 & 1,30 & 2,20 & 0,44 & 1,37 \\
Terapia Ocupacional & 0,02 & 0,12 & 0,18 & 0,42 & 0,10 & 0,25 \\
Psicologia & 0,83 & 1,87 & 4,04 & 9,12 & 4,89 & 5,41 \\
Assistente Social & 2,87 & 2,81 & 2,47 & 5,54 & 3,52 & 3,97 \\
Medicina Veterinária & 0,82 & 1,14 & 3,60 & 2,00 & 3,21 & 1,97 \\
Nutrição & $*$ & 0,76 & 1,52 & 1,47 & 0,76 & $*$ \\
Fonoaudiologia & 0,06 & 0,24 & 0,73 & $*$ & $0,03^{*}$ & $*$ \\
\hline
\end{tabular}

Fonte: $\mathrm{CF}^{\prime}$ ( ${ }^{*}=$ sem informação).

A rede particular de ensino mostra-se com grande predomínio na oferta de cursos para a formação de psicólogos, fonoaudiólogos, assistentes sociais e fisioterapeutas. Os cursos de formação de médicos veterinários tem uma situação oposta, com $71,4 \%$ em instituições públicas de ensino.

Da mesma forma que a distribuição dos profissionais, a oferta de cursos também está concentrada na Região Sudeste. 
TABELA 19

Distribuição dos Cursos de Várias Profissões de Saúde, Segundo a Entidade Mantenedora, por Região, Brasil, 1992

\begin{tabular}{lcrrrrrrrrrrrr}
\hline Cursos & Norte & \multicolumn{1}{c}{ Nordeste } & Sudeste & \multicolumn{2}{c}{ Sul } & \multicolumn{2}{c}{ C. Oeste } & \multicolumn{2}{c}{ Brasil } \\
\hline & Publ. & Part. & Publ. Part. & Publ. Part. & Publ. Part. Publ. Part. Publ. Part. Total \\
\hline Farmácia & 1 & 1 & 7 & 1 & 8 & 16 & 7 & 3 & 2 & 2 & 25 & 23 & 48 \\
Fisioterapia & 1 & & 4 & 2 & 5 & 22 & 2 & 7 & 0 & 2 & 12 & 33 & 45 \\
Terap. Ocup. & 1 & & 1 & 2 & 3 & 7 & 0 & 3 & 0 & & 5 & 12 & 17 \\
Psicologia & 2 & 1 & 7 & 8 & 10 & 47 & 6 & 14 & 2 & 4 & 27 & 74 & 101 \\
Medicina Veter. & 1 & & 5 & & 9 & 7 & 6 & 3 & 4 & & 25 & 10 & 35 \\
Serviço Social & 3 & 2 & 6 & 2 & 7 & 21 & 7 & 9 & 2 & 2 & 25 & 36 & 61 \\
Fonoaudiologia & 0 & & 0 & 2 & 2 & 18 & 1 & 7 & 0 & 1 & 3 & 28 & 31 \\
\hline
\end{tabular}

\section{PÓS-GRADUAÇÃo}

Dentro de um sistema universitário marcado por graves deficiências, a pós-graduação no Brasil tem sido considerada como um setor bem-sucedido 14 , "embora constitua um setor restrito e esteja muito desigualmente distribuída entre as instituições de ensino superior".

Os dados disponíveis estão agregados sob a área "profissões da saúde" que compreende: educação física, enfermagem, farmácia, fonoaudiologia, medicina (administração da saúde, alergia e imunologia, anestesiologia, angiologia, cardiologia, cirurgia médica, clinica geral, dermatologia, doenças infecciosas e parasitárias, endocrinologia, gastroenterologia, ginecologia e obstetrícia, hematologia, medicina preventiva e social, nefrologia, neurologia, nutrologia, oftalmologia ortopedia e traumatologia, otorrinolaringologia, patologia, pediatria, pneumologia, psiquiatria, radiologia, reumatologia, urologia), nutrição e odontologia.

Em seu conjunto, os dados e séries indicam uma tendência ao crescimento. A concentração dos cursos na área pública faz um contraponto com a graduação, que tem no setor privado parcela importante de seus cursos. A Região Sudeste, mais até que a graduação ou a residência médica, concentra a imensa maioria dos cursos, tanto de mestrado como doutorado. O número de bolsas concedidas alcança aproximadamente a metade dos alunos novos.

14 Durhan, E. R.; Gusso, D. A. A pós-graduação no Brasil: problemas e deficiências. CAPEs, Brasília, 1991. 
A Coordenação de Aperfeiçoamento de Pessoal de Nível Superior CAPES - é o órgão responsável pela coordenação e operação do sistema de avaliação e de subsidiar o Conselho Federal de Educação no processo de credenciamento dos programas. Os sistemas de bolsas de estudo de pós-graduação são compartidos entre e o Conselho Nacional de Desenvolvimento Científico e Tecnológico - CNPq. No âmbito federal, a Financiadora de Estudos e Pesquisas - FINEP, se associa ao CNPq e à CAPES no financiamento de linhas de pesquisas e programas de pós-graduação. No âmbito estadual funcionam algumas agencias de fomento à pesquisa, destacando-se as agências dos Estados de São Paulo, Rio Grande do Sul e Minas Gerais.

\section{TABELA 20}

Distribuição dos Cursos e dos Alunos Inscritos nos Curso de Pós-graduação, nas Profissões da Saúde, Brasil, 1989

\begin{tabular}{lrcr}
\hline & Mestrado & Doutorado & Total \\
\hline Cursos & 219 & 130 & 349 \\
Alunos & 4.370 & 1.342 & 5.712 \\
\hline
\end{tabular}

Fonte: CAPES.

\section{GRÁFICO 10}

Distribuição Percentual dos Alunos Matriculados nos Cursos de Pós-graduação das Profissões de Saúde, Segundo a Dependência Administrativa, Brasil, 1989

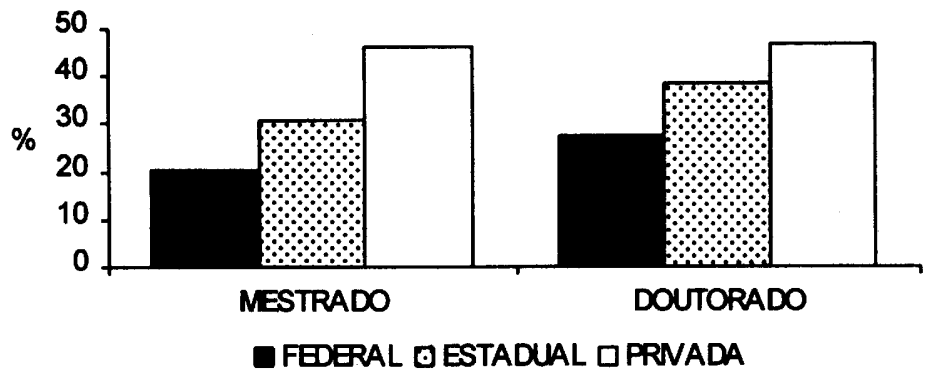

Fonte: CAPES. 


\section{TABELA 21}

Distribuição Percentual dos Alunos Vinculados aos Programas de Pós-graduação das Profissões da Saúde, por Região e Nivel do Curso, Brasil, 1989

\begin{tabular}{lcc}
\hline Regiões & Mestrado & Doutorado \\
\hline Norte & 0,00 & 0,00 \\
Nordeste & 6,50 & 2,50 \\
Sudeste & 83,00 & 94,30 \\
Sul & 9,60 & 3,20 \\
Centro Oeste & 0,90 & 0,00 \\
\hline Brasil & 100,00 & 100,00 \\
\hline
\end{tabular}

Fonte: CAPES.

\section{GRÁFICO 11}

Distribuição dos Alunos de Mestrado nos Cursos das Profissões da Saúde, $1986 / 1990$
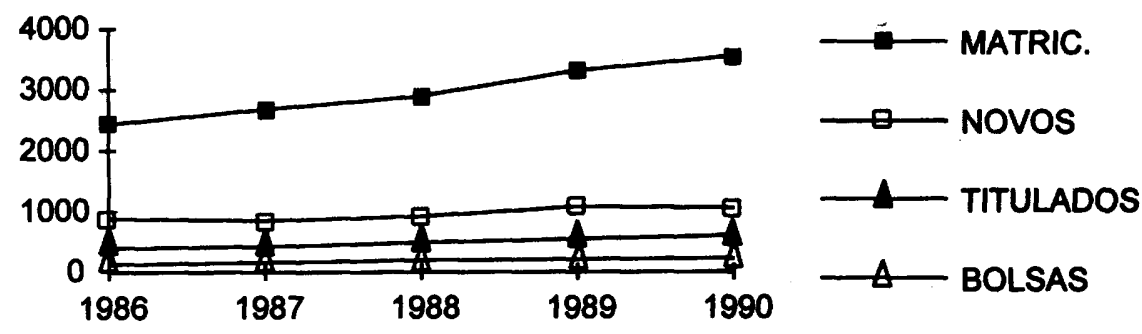

Fonte: CAPLS.

\section{GRÁFICO 12}

Distribuição dos Alunos de Doutorado nos Cursos das Profissões da Saúde, Brasil, 1986/1990

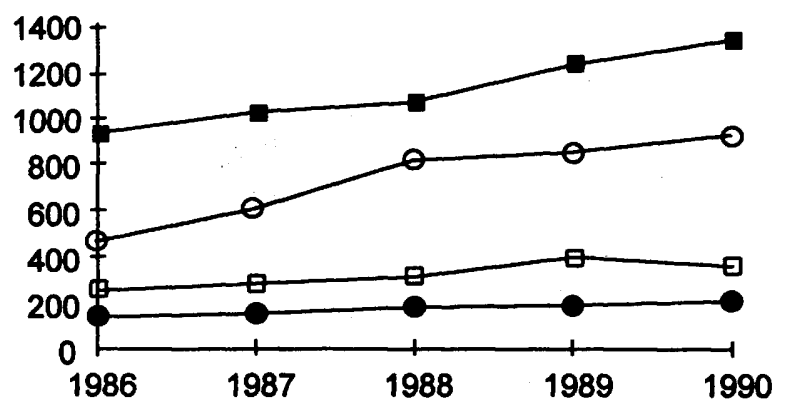

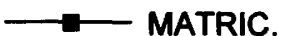

$\longrightarrow$ NOVOS

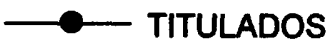

- BOLSAS

Fonte: CAPES. 


\section{LEGISLAÇÃO SOBRE REGULAMENTAÇÃO DO EXERCÍCIO PROFISSIONAL E CRIAÇÃO DOS CONSELHOS DAS PROFISSÕES DA SAÚDE}

\begin{tabular}{|c|c|c|}
\hline Documento & Data & Ementa \\
\hline Decreto 20.862 & $28 / 12 / 1931$ & $\begin{array}{l}\text { Regula o exercício da odontologia pelos } \\
\text { dentistas práticos. }\end{array}$ \\
\hline Decreto 20.931 & $11 / 01 / 1932$ & $\begin{array}{l}\text { Regula e fiscaliza o exercício da medicina, } \\
\text { da odontologia, da veterinária e das } \\
\text { profissões de farmacêutico, parteira e } \\
\text { enfermeira no Brasil. }\end{array}$ \\
\hline Decreto 21.073 & $22 / 02 / 1932$ & Regula o exercício da odontologia. \\
\hline Decreto-Lei 3.171 & $02 / 04 / 1941$ & $\begin{array}{l}\text { Cria o Serviço de Fiscalização da } \\
\text { Medicina e Farmácia. }\end{array}$ \\
\hline Decreto-Lei 7.718 & $09 / 07 / 1945$ & $\begin{array}{l}\text { Dispõe sobre a formação do cirurgião- } \\
\text { dentista e regulamenta a profissão. }\end{array}$ \\
\hline Decreto-Lei 7.955 & $13 / 09 / 1945$ & $\begin{array}{l}\text { Cria os Conselhos Federal e Regional de } \\
\text { Medicina. }\end{array}$ \\
\hline Decreto-Lei 8.778 & $22 / 01 / 1946$ & $\begin{array}{l}\text { Regula os exames de habilitação para os } \\
\text { auxiliares de enfermagem. }\end{array}$ \\
\hline Lei 775 & $06 / 08 / 1949$ & $\begin{array}{l}\text { Dispöe sobre o ensino da enfermagem no } \\
\text { País. }\end{array}$ \\
\hline Lei 1.314 & $15 / 01 / 1951$ & $\begin{array}{l}\text { Regula o exercício dos cirurgiões- } \\
\text { dentistas. }\end{array}$ \\
\hline Lei 2.604 & $16 / 09 / 1955$ & Regula o exercício da enfermagem. \\
\hline Lei 3.268 & $30 / 09 / 1957$ & Dispõe sobre os Conselhos de Medicina. \\
\hline Decreto 44.045 & $19 / 07 / 1958$ & $\begin{array}{l}\text { Aprova o regulamento do Conselho } \\
\text { Federal e dos Conselhos Regionais de } \\
\text { Medicina. }\end{array}$ \\
\hline Lei 3.820 & $11 / 11 / 1960$ & Regulamenta a profissão de farmacêutico. \\
\hline Lei 3.640 & $10 / 10 / 1959$ & $\begin{array}{l}\text { Revigora o Decreto-Lei } 8.778 \text { de } 1946 \\
\text { que dispõe sobre o exercício da } \\
\text { enfermagem e lhe altera o alcance do } \\
\text { artigo } 1 \% \text {. }\end{array}$ \\
\hline Decreto 50.387 & $28 / 03 / 1961$ & $\begin{array}{l}\text { Regula o exercício da enfermagem e suas } \\
\text { funções auxiliares. }\end{array}$ \\
\hline Lei 3.999 & $15 / 12 / 1961$ & $\begin{array}{l}\text { Altera o salário-mínimo dos médicos e } \\
\text { cirurgiōes dentistas. }\end{array}$ \\
\hline
\end{tabular}




Documento Data Ementa

Lei 4.119

Lei 4.324

Lei 5.081

Decreto-Lei 150

Lei 5.517

Decreto 64.704

Decreto-Lei 938

Decreto-Lei 67.057

Decreto 67.284

Decreto 68.704

Lei 5.766

Lei 5.905

Lei 6.316

Lei 6.583

Decreto 79.137

Decreto 79.822
$27 / 08 / 1962$

14/04/1964

24/08/1966

$09 / 02 / 1967$

$23 / 10 / 1968$

17/06/1969

$13 / 10 / 1969$

$14 / 08 / 1970$

28/09/1970

03/06/1971

20/12/1971

$02 / 07 / 1973$

$17 / 12 / 1975$

$20 / 10 / 1978$

$18 / 01 / 1977$

$27 / 06 / 1977$
Dispõe sobre os cursos de formação em psicologia e regulamenta a profissão de psicólogo.

Cria os Conselhos Federal e Regionais de Odontologia.

Regula o exercício da odontologia.

Dispensa de registro no Serv. Nac. de Fiscalização da Medicina e da Farmácia os diplomas expedidos por escolas ou faculdades de medicina e farmácia.

Dispõe sobre o exercício profissional do médico veterinário e cria os Conselhos Federal e Regionais de Medicina Veterinária.

Aprova o regulamento da profissão de médico veterinário e dos Conselhos de Medicina Veterinária.

Regulamenta o exercício profissional do fisioterapeuta e terapeuta ocupacional.

Dispõe sobre a vinculação do Conselho Federal de Odontologia e Conselhos Regionais de Odontologia.

Aprova o regulamento da Comissão de Enquadramento Sindical.

Regulamenta a Lei 4.324 que criou os Conselhos de Odontologia.

Cria os Conselhos Federal e Regionais de Psicologia.

Cria os Conselhos Federal e Regional de Enfermagem.

Cria os Conselhos Federal e Regionais de Fisioterapia e Terapia Ocupacional.

Cria os Conselhos Federal e Regionais de Nutricionista e regulamenta seu funcionamento.

Inclui os conselhos na classificação de órgãos de deliberação coletiva.

Regulamenta a Lei 5.766 de 20/12/71 que criou os Conselhos Federal e Regionais de Psicologia. 


\begin{tabular}{|c|c|c|}
\hline Documento & Data & Ementa \\
\hline Lei 6.684 & $08 / 09 / 1979$ & $\begin{array}{l}\text { Regulamenta a profissão de biólogo e } \\
\text { biomédico e cria os Conselhos Federal e } \\
\text { Regionais de Biologia e Biomedicina. }\end{array}$ \\
\hline Lei 6.965 & $09 / 12 / 1981$ & $\begin{array}{l}\text { Regulamenta o exercício profissional de } \\
\text { fonoaudiólogo. }\end{array}$ \\
\hline Lei 6.839 & $30 / 10 / 1980$ & Dispõe sobre o registro de empresas. \\
\hline Lei 6.994 & $26 / 05 / 1982$ & $\begin{array}{l}\text { Dispõe sobre a vinculação dos Conselhos } \\
\text { ao Ministério do Trabalho. }\end{array}$ \\
\hline Decreto 87.497 & $19 / 08 / 1982$ & $\begin{array}{l}\text { Regulamenta normas para contratação de } \\
\text { estudantes de estabelecimentos de ensino } \\
\text { superior e de } 2^{*} \text { grau regular e supletivo, } \\
\text { na condição de estagiários. }\end{array}$ \\
\hline Lei 7.017 & $30 / 08 / 1982$ & $\begin{array}{l}\text { Dispõe sobre o desmembramento dos } \\
\text { Conselhos Federal e Regionais de Biologia } \\
\text { e Biomedicina. }\end{array}$ \\
\hline Decreto 88.147 & $08 / 03 / 1983$ & $\begin{array}{l}\text { Regulamenta a Lei } 6.994 \text { de } 1982 \text { que } \\
\text { dispõe sobre a vinculação dos Conselhos } \\
\text { ao Ministério da Trabalho. }\end{array}$ \\
\hline Lei 7.498 & $25 / 06 / 1986$ & $\begin{array}{l}\text { Dispõe sobre a regulamentação do } \\
\text { exercício da enfermagem. }\end{array}$ \\
\hline Decreto 98.377 & $08 / 11 / 1989$ & $\begin{array}{l}\text { Dispõe sobre a criação de novos cursos } \\
\text { de ensino superior na área de saúde. }\end{array}$ \\
\hline Lei 8.138 & $28 / 12 / 1990$ & $\begin{array}{l}\text { Dispõe sobre as atividades do médico } \\
\text { residente e assegura o valor da bolsa de } \\
\text { estudo. }\end{array}$ \\
\hline Lei 8.234 & $17 / 09 / 1991$ & $\begin{array}{l}\text { Regulamenta o exercício profisssional de } \\
\text { nutricionista. }\end{array}$ \\
\hline Lei 8.662 & $07 / 06 / 1993$ & $\begin{array}{l}\text { Regulamenta o exercício profisssional do } \\
\text { assistente social. }\end{array}$ \\
\hline
\end{tabular}




\title{
FormaçÃo E MERCADO DE TRABALHO DE ALGUMAS CATEGORIAS PROFISSIONAIS DE SAÚDE NO URUGUAI
}

\author{
Féllx Rigoll \\ Milagros Sugo \\ Joaquin Serra
}

\section{INTRODUÇÃo}

Embora heterogêneas e dispersas, as informações a que se tem acesso no Uruguai sobre a disponibilidade, a distribuição e o aproveitamento de recursos humanos para a saúde refletem a evolução histórica do modelo de atenção predominante num quadro demográfico, econômico e político com algumas características próprias e outras comuns aos países latino-americanos.

Resumidamente, pode-se dizer que o pais adotou um modelo com forte influência da medicalização e da superespecialização para uma população escassa, envelhecida e com marcante tendência ao empobrecimento.

As políticas de recursos humanos, no que se referem ao tipo, à qualidade e à necessidade de pessoal, nem sempre são conjuntas e combinadas entre os organismos diretores, empregadores e formadores, e algumas vezes encontraram resistências por parte da população. Um exemplo disso foi a pressão exercida para anular as medidas de limitação de vagas na universida- 
de e o conseqüente aumento do número de matriculados, apesar do amplo reconhecimento de que o mercado de trabalho era cada vez mais reduzido.

Essa mão-de-obra em crescimento inclui um número muito elevado de profissionais específicos de saúde, que constituem um segmento importante do mercado de trabalho.

Existe uma única Universidade pública no Uruguai, que data de meados do século XIX e que conta com Faculdades e Escolas. A universidade particular foi criada há pouco tempo e tem escassa vinculação com o campo da saúde.

Segundo dados extraídos da Dirección Ceneral de Estadísticas y Censo (DGEC), a velocidade do crescimento das matrículas universitárias é muito superior ao crescimento da população do país: para o período 1976-1984, por exemplo, com um crescimento zero da população, duplicou-se o número de matrículas universitárias.

Esse forte crescimento mostra características diferentes nas Faculdades e nas Escolas universitárias: as primeiras mostraram pequeno aumento no número de matriculados, ao passo que nas últimas o aumento foi bem maior. Muitos fatores podem ter influenciado esse fenômeno - tais como, entre outros, a proliferação de cursos curtos num mercado de trabalho reduzido, os exames vestibulares nas Faculdades ou a limitação de vagas nos anos de 1982 e 1983.

A evolução histórica mostra que a origem da maior parte dos alunos é urbana, o que reflete a dinâmica migratória da população do país.

A maioria dos formados pertence ao sexo feminino, especialmente no setor saúde, fato relacionado à urbanização, às mudanças das atribuições sociais do homem e da mulher e à deterioração econômica, que obriga a muther a preparar-se para atividades profissionais não-domésticas (Tabela 1). 
TABELA 1

Número de Egressos da Universidade Uruguai, 1989

\begin{tabular}{lrrr}
\hline & Homens & Mulheres & Total \\
\hline Medicina & 228 & 281 & 509 \\
Odontologia & 32 & 103 & 135 \\
Veterinária & 71 & 37 & 108 \\
Outras & 895 & 710 & 1.605 \\
\hline Total Faculdades & 1.226 & 1.131 & 2.357 \\
\hline Aux. Odontológico & 42 & 94 & 136 \\
Enfermagem & 2 & 97 & 99 \\
Nutrição & 0 & 24 & 24 \\
Parteiras & 0 & 2 & 2 \\
Psicologia & 26 & 162 & 188 \\
Serviço Social & 2 & 55 & 57 \\
Tecnologia Médica & 44 & 171 & 215 \\
Outras & 29 & 96 & 125 \\
\hline Total Escolas & 145 & 701 & 846 \\
\hline Total & 1.371 & 1.832 & 3.203 \\
\hline
\end{tabular}

Fonte: Dirección General de Planeamiento Universitario, 1990.

\section{Mercado de Trabalho para Profissionais de Saúde}

O fenômeno mundial de crescimento da mão-de-obra empregada no setor terciário e, dentro deste, majoritariamente, no setor saúde, verifica-se também no Uruguai. Embora o acesso às informações utilizadas pela DGEC seja restrito, é possível calcular a evolução do setor através das tabelas dos Censos Econômicos Nacionais de 1978 e 1988, apresentadas na Tabela 2.

\section{Tabela 2}

Número de Profissionais em Serviços de Atenção Médica* Uruguai, 1978 e 1988

\begin{tabular}{cccc}
\hline Ano & Montevidéu & Interior & Total \\
\hline 1978 & 15.968 & 19.372 & 35.340 \\
1988 & 43.729 & 19.437 & 63.166 \\
\hline
\end{tabular}

Fonte: DCEC. Censos Económicos Nacionales 1978-1988.

* Código 9331, classificação Cilu, DGEC. 
Segundo estes dados, a força de trabalho empregada em instituições médicas (pois assim estão definidas pelo Censo) alcançaria atualmente $7 \%$ da PEA, ao passo que há uma década esta percentagem era de $4,3 \%$, tendo sofrido um acréscimo de $62 \%$.

Dentro da mão-de-obra empregada nos serviços de atenção médica distinguimos, além dos profissionais específicos da saúde, um grupo de profissionais não específicos do setor - ocupados com administração, serviços gerais etc. $\mathrm{O}$ alto grau de especialização dos profissionais do primeiro grupo dificulta sua relocação para outros ramos da atividade econômica em caso de retração da oferta de trabalho no seu setor.

Dentro dessas categorias específicas, a profissão médica motivou o maior número de estudos e revisões, o que possibilita, no presente trabalho, um desenvolvimento mais detalhado das informações a ela referentes.

\section{MÉDICOS}

\section{Graduação}

A formação básica de médicos é feita na Faculdade de Medicina criada em 1875, que outorga o título de "Doutor em Medicina".

Uma vez finalizado o nível secundário da educação, o ingresso do aluno na Faculdade é feito por meio de inscrição anual; não se cobra matrícula e atualmente inexistem exames de admissão ou limite de vagas. Não obstante, observa-se um declínio natural no número de matrículas, em contraste com o aumento global do número de estudantes universitários no país.

A duração da graduação é de oito anos. Para a obtenção da habilitação exige-se, desde 1991, um ano de internato, dos quais um dos trimestres é realizado no interior do país.

Os programas curriculares não são estáticos, e atualmente tenta-se reverter a tendência biologicista e hierarquizar a relação médico-paciente, com a inserção do estudante na comunidade, desenvolvendo-se, ao longo da carreira, os aspectos psicossociais em que tal relação implica.

Várias instituições participam da formação prática dos médicos: a universidade, o Ministério da Saúde Pública e, em alguns casos, o Município de Montevidéu. A Faculdade de Medicina é responsável pela concepção, elaboração e avaliação dos cursos, ao passo que as demais instituições asseguram um local para prática e colaboram com o ensino favorecendo a formação de recursos humanos.

\section{Pós-Graduação}

A Escola de Pós-Graduação criada em 1953 é a responsável pelos cursos de especialização médica através das Cátedras e Departamentos da Faculdade de Medicina, outorgando o título de "Especialista". 
Em 1983, as especialidades eram 44; atualmente existem várias outras em trâmite de reconhecimento formal. A distribuição dos médicos em atividade por especialidade para os anos de 1974 e 1992 é apresentada na Tabela 3 .

\section{TABELA 3}

Distribuição de Médicos Ativos por Especialidade Uruguai, 1974 e 1992

\begin{tabular}{lrrrrr}
\hline & 1974 & & & 1992 & \\
\hline Especialidade & $N^{*}$ & $\%$ & $N^{2}$ & & $\%$ \\
\hline Anestesiologia & 93 & 2,26 & 262 & 2,68 & 181,7 \\
Cardiologia & 138 & 3,35 & 496 & 4,15 & 194,20 \\
Cirurgia & 343 & 8,34 & 404 & 4,13 & 17,20 \\
Geriatria & 6 & 0,15 & 74 & 0,76 & $1.133,33$ \\
Ginecologia & 254 & 6,17 & 459 & 4,69 & 80.71 \\
Patologia Clínica & 41 & 1,00 & 126 & 1,29 & 207,32 \\
Medicina Interna & 29 & 0,70 & 483 & 4,93 & $1.565,52$ \\
Nefrologia & 2 & 0,05 & 70 & 0,72 & $3.400,00$ \\
Oftalmologia & 85 & 2,07 & 142 & 1,45 & 67,06 \\
Pediatria & 492 & 11,96 & 877 & 8,96 & 78,25 \\
Psiquiatria & 154 & 3,74 & 446 & 4,56 & 189,61 \\
Psiquiatria Infantil & 10 & 0,24 & 71 & 0,73 & 610,00 \\
Reumatologia & 36 & 0,87 & 104 & 1,06 & 188,88 \\
Medicina Intensiva & 3 & 0,07 & 156 & 1,59 & $5.100,00$ \\
Traumatologia & 64 & 1,56 & 125 & 1,28 & 95,31 \\
Outras* & 2.365 & 42,53 & 5.584 & 42,98 & 236,00 \\
\hline Total & 4.115 & 100 & 9.789 & 100 & 137,89 \\
\hline
\end{tabular}

Fonte: SMU Padron Médico Nacional. 1974-1992.

* Inclusive Medicina Geral.

Como demonstra a Tabela, algumas especialidades - como Medicina Intensiva, Nefrologia, Medicina Interna e Geriatria - incrementaram radicalmente seu número de médicos em atividade em números absolutos e freqüências relativas; por outro lado, as especialidades básicas - cirurgia, pediatria e ginecologia - diminuíram seu crescimento, também nas percentagens. Algumas das causas desse fenômeno podem ser o envelhecimento da população nacional, o desenvolvimento e a introdução de novas tecnologias, a saturação do mercado de trabalho em algumas especialidades e a criação, em 1979, de um sistema de financiamento especial (Lei 14.897) para a presta- 
ção de serviços no âmbito da medicina altamente especializada, favorecendo o desenvolvimento de práticas médicas de alta tecnologia.

Os cursos de pós-graduação têm duração não menor que três anos. Pode-se obter o título de especialista através de duas vias:

\section{1) Cursos e Residências}

O acesso aos cursos se realiza mediante livre inscrição anual ou bianual, dependendo da especialidade. A freqüência às aulas teóricas e práticas é diária, em geral com a obrigatoriedade de 12 ou 24 horas semanais. Existem também regimes especiais de freqüência para médicos do interior do país.

A Comissão Nacional de Residências Médicas, criada por Lei Nacional em 1983, é encarregada de administrar o Programa de Residências. Cada ano, mediante concurso, ingressam cem novos residentes e dez Chefes de Residência. Em algumas especialidades, como, por exemplo, a cirurgia geral, o ingresso é limitado exclusivamente à residência correspondente.

2) Notória Competência ou Atuação Documentada

A obtenção do título de especialista pela via de notória competência ou atuação documentada exige a apresentação de documentação que comprove esse fato e o parecer de comissões de assessoria pertencentes à Escola de Pós-Graduação.

\section{Participação de Estrangeiros na Formação}

Um aspecto de particular importância no quadro de um processo de integração é constituído pela participação de estudantes estrangeiros na graduação e na pós-graduação.

Os pedidos de revalidação de cursos de graduação e do título de médico são canalizadas pela Faculdade de Medicina. O maior número de solicitações provém de uruguaios que realizaram seus estudos no exterior.

A universidade tem convênios com dez países latino-americanos e um país europeu; entre os primeiros, encontram-se todos os países integrantes do MERCOSUL. Não são realizadas revalidações com terceiros países.

Por decisão do Consejo Director Central, a Comissión de Revalidación da Faculdade de Medicina está habilitada a considerar as solicitações de países com os quais não existem convênios firmados, mas que possuam universidades consideradas aptas para a adequada formação de recursos humanos.

Com relação aos títulos de especialistas, as revalidações são competência da Escola de Pós-Graduação. Para cada pedido forma-se uma banca que julga e analisa especialmente o conteúdo e o tipo das matérias cursadas, exigindo, em alguns casos, monografia e exame. 

anuais.

O número de pedidos de revalidação de títulos oscila entre dez e vinte

Quanto aos destinos e procedências, mantêm-se as mesmas características descritas para os graduados, com a ressalva de que o destino preferido pelos médicos uruguaios inclui especialmente os países europeus.

A Escola de Pós-Graduação, com quase quarenta anos de existência, recebe anualmente entre cinqüenta e cem estudantes estrangeiros.

Em 1990 ficou decidida a cobrança de uma taxa anual de US\$2.000 por estudante, que só começou a ser efetuada a partir do presente ano.

A origem dos médicos que buscam estudos de especialização no Uruguai é fundamentalmente a América do Sul (Brasil, Colômbia e Argentina) e a Europa (Espanha). As especialidades preferidas incluem pediatria, ginecologia, psiquiatria, neurologia e oftalmologia.

\section{Demografia Médica}

a) Número e Distribuição Geográfica

Desde fins do século passado o Uruguai conta com uma alta oferta de médicos, em comparação com o resto da América Latina. Em 1889 existiam 7 médicos para 10.000 habitantes; vinte anos depois, em 1908, a taxa elevara-se para 8 médicos para 10.000 habitantes (Rial, 1983; Rigoli, 1991). A evolução dos últimos anos pode ser observada na Tabela 4.

\section{TABELA 4}

Número de Médicos por 10.000 Habitantes

Uruguai, 1962-1992

\begin{tabular}{ccccc}
\hline Anos & $\begin{array}{c}\text { Número de } \\
\text { Médicos }\end{array}$ & \multicolumn{3}{c}{ Taxa para 10.000 hab. } \\
& Total & Montevidéu & Interior \\
\hline 1962 & 3100 & 11 & 20 & 4 \\
1970 & 2689 & 10 & 17 & 5 \\
1980 & 5972 & 21 & 40 & 8 \\
1992 & 11530 & 37 & 68 & 12 \\
\hline
\end{tabular}

Um aumento muito significativo no número de egressos da Faculdade de Medicina a partir da década de 70 , a diminuição da imigração médica e a estabilidade numérica da população do país fizeram com que em 30 anos triplicasse o número de médicos para 10.000 habitantes.

Diferentes estimativas técnicas da dotação ideal de recursos médicos necessários para assistir eficazmente uma população variam entre 8 e 13 
médicos para cada 10.000 habitantes (Schonfeld, OPAS, 1973). Existe no Uruguai, por conseguinte, uma importante superoferta de médicos. Esse fato terá diversas manifestações no mercado de trabalho e repercutirá de forma importante no Sistema Nacional de Saúde.

A análise da disponibilidade de médicos por região mostra uma nítida diferença da situação em Montevidéu e no resto do país (Tabela 4):

A diferença reflete a distribuição desigual de médicos no território nacional. Em Montevidéu, onde se localizam $45 \%$ da população, residem $80 \%$ dos médicos, ao passo que no resto do país, onde habitam $55 \%$ dos uruguaios, localizam-se apenas $20 \%$ dos médicos. No entanto, uma política de relocação dos médicos não parece ser uma solução eficaz para o problema de superoferta de médicos, pois, como se observa na Tabela 4, também no interior do país existe uma adequada oferta de profissionais.

\section{b) Características Demográficas dos Médicos}

Nos últimos 30 anos, a população médica registrou uma importante feminização - em 1962, apenas 14\% dos médicos eram mulheres (SMU, 1973), ao passo que em 1992 as mulheres já constituem $41 \%$. A atual composição por sexo das matrículas universitárias permite prever que essa feminização da profissão será acentuada nos anos vindouros.

Como resultado do sistema de papéis familiares e dos valores culturais imperantes, a mulher tem participação secundária no mercado de trabalho, reduzindo suas taxas de atividade e emprego. Dessa forma, a feminização da oferta de trabalho médico contrabalança o efeito da entrada maciça de profissionais jovens no mercado de trabalho.

A expansão do número de matrículas na Faculdade de Medicina, com o conseqüente aumento do número de formados, modificou a estrutura etária do corpo médico, aumentando a incidência dos estratos mais jovens.

As dificuldades de emprego são mais críticas na faixa etária entre 25 e 39 anos. Por conseguinte, é nessa faixa que existe um maior estímulo à superespecialização e à introdução de novas tecnologias.

\section{Grau de Especialização dos Médicos}

O grau de especialização dos médicos uruguaios cresceu notavelmente nos últimos anos. Esse processo explica-se, em parte, pelas mudanças científico-tecnológicas; além disso, a superespecialização tem sido uma das estratégias desenvolvidas pelos médicos para melhorar suas possibilidades de emprego e ingresso num mercado saturado. Essa tendência acelerou-se nos últimos anos, produzindo um crescimento da "segunda especialização". Em 1985, 67\% dos médicos possuíam uma especialização, e deles, $12 \%$ possuiam mais que duas especializações, ao passo que em 1990 são $90 \%$ os 
que possuem uma e chegam a $42 \%$ os que possuem mais de duas. (SMUFEMI, 1985; SMU, 1990).

\section{Mercado de Trabalho}

Segundo dados do Padrón Médico Nacional, no mês de junho de 1992 existiam no Uruguai 9.789 médicos ativos, 568 inativos e 1.173 no exterior.

Segundo as pesquisas realizadas em 1980 e 1985, pelo menos $30 \%$ dos médicos eram subocupados ou desocupados.

Em 1990, a Encuesta Médica Nacional calcula a taxa de ociosidade em $7 \%$, e em $33 \%$ a percentagem de médicos que recebem, por sua atividade profissional, menos que dois Salários-Bases Médicos. Um Salário-Base Médico equivale a cerca de US\$200.

Essa problemática afeta principalmente o médico jovem e significa que, em termos absolutos, atualmente mais de 3.000 profissionais têm dificuldade de emprego.

\section{Modalidades de Vinculação Jurídica dos Médicos às Instituições}

Como se verá adiante, a norma de vinculação trabalhista médica no Uruguai é de multiemprego. Portanto, as considerações seguintes referem-se a postos de trabalho. Em geral, cada médico tem vários dos tipos de vinculação jurídica aqui descritos.

No setor público, os médicos são funcionários assalariados, recebendo um salário fixo mensal que varia segundo o nível hierárquico do profissional.

Às instituições de pré-pagamento (no Uruguai, chamadas Instituciones de Asistencia Médica Colectiva, IAMC), o médico é vinculado por meio de dois mecanismos jurídicos distintos: o contrato salarial ou o contrato de prestação de serviços.

No primeiro caso, existe uma situação de dependência do médico à instituição, e a ele se aplica a legislação trabalhista e os acordos salariais. Entre seus direitos, cabe destacar: licenças, gratificação natalina, férias pagas, indenização por demissão, aposentadoria e o direito a salários-mínimos e condições de trabalho fixadas pelos acordos salariais.

O segundo grupo é integrado pelos profissionais que atuam na referência por alta especialização, mantendo, por isso, apenas vínculos aleatórios ou efêmeros com as IAMCs. Eles atendem pacientes referidos devido a graus de complexidade não cobertos pela instituição. Seus honorários são fixados pelas sociedades que os agrupam; não thes é aplicada a legislação trabalhista, tampouco os convênios salariais. A fixação das tarifas é realizada através de critérios diferentes e em ocasiōes distintas dos acordos salariais.

Os diversos sistemas de remuneração do trabalho médico podem ser resumidos da seguinte forma: 
1) Pagamento de uma tarifa por parte das IAMC. Essa é a forma como as IAMC freqüentemente remuneram os médicos muito especializados ou de referência.

2) Pagamento de um salário variável por cada ato médico realizado; a remuneração final dependerá do número de atos efetuados.

3) Pagamento de um salário misto, uma parte fixa e uma parte variável. Certas funções são pagas por hora e outras por ato médico. Essa é a forma estabelecida pelos acordos salariais e é a mais freqüente nas IAMCs. As atividades de consultório, plantões, atendimento de urgência etc., são pagas por hora, e as atividades esporádicas - como, por exemplo, intervenções cirúrgicas, visitas a domicílio etc. - são remuneradas por serviço prestado.

4) Pagamento de um salário fixo segundo o número mensal de horas contratadas. Esse sistema foi introduzido nos últimos anos nas IAMCs de maior porte. Sua aplicação acompanha a criação de hierarquia médica por especialidade ou serviço. $\mathrm{O}$ custo/hora dependerá do grau e da especialidade do médico, e do tipo de trabalho por ele realizado. Esse é também o sistema de pagamento do setor público.

5) Pagamento direto de um honorário por parte do paciente ao médico, modalidade que se mantém exclusivamente no exercício liberal da profissão e nos seguros parciais destinados a setores de alto poder aquisitivo. Calcula-se que menos de $9 \%$ da população goza de assistência privada. Essa baixa incidência da atividade liberal na prestação de assistência reflete-se no número de médicos que recebem honorários: na Encuesta Médica Nacional de 1990, apenas $17 \%$ dos entrevistados declarou recebê-los em alguma oportunidade.

\section{Número de Cargos Médicos (Tabela 5)}

Em outubro de 1991 existiam 12.396 cargos nas IAMC, sendo $9.798 \mathrm{em}$ Montevidéu e 2.598 no interior. Os hospitais e os seguros parciais possuem mais 723 cargos, totalizando 13.119 cargos no setor privado.

Em setembro de 1990 existiam 2.648 cargos no Ministério da Saúde Pública; no resto do setor público - Saúde militar, Saúde policial, administração central, prefeituras etc. - calcula-se mais 4.000 cargos.

Levando-se em conta que $85 \%$ dos médicos ativos ocupam algum cargo e que a média de cargos acumulados por cada médico assalariado oscila entre 2,5 e 2,7, existiriam, no total, de 20.700 a 22.400 cargos. A diferença entre os cargos calculados e os conhecidos - entre 1.000 e 2.700 - fica distribuída por clínicas de diagnóstico e tratamento (centros de diálise, tomografia, análises clínicas etc.) e empresas que não fazem propriamente parte do setor (clínicas de emagrecimento, peritos médicos etc.). 


\section{TABELA 5}

Evolução do Número de Cargos e de Médicos Ativos Uruguai, 1966-1991

\begin{tabular}{lcrrc}
\hline & 1966 & 1980 & 1991 & Variação \\
\hline Médicos ativos & 2.667 & 5.972 & 9.789 & $267 \%$ \\
Cargos IAMC & $3800^{\star}$ & 8.726 & 13.119 & $245 \%$ \\
Cargos MSP & 1.049 & 1.401 & 2.642 & $151 \%$ \\
\hline Cargos/Médico & 1,81 & 1,61 & 1,70 & - \\
\hline
\end{tabular}

Fonte; Yanicelli 1972, Meerhoff 1988, sMU-Serra 1992.

*Em 1966 foram computados apenas os cargos de Montevidéu.

O crescimento do número de médicos ativos esteve associado a uma expansão similar no número de cargos, embora esses últimos tenham aumentado em ritmo levemente mais lento. Esse comportamento da demanda institucional de trabalho médico impediu que se registrassem altas taxas de desemprego entre os médicos. Como os recursos disponíveis para a remuneração do trabalho médico não cresceram na mesma proporção, o aumento do número de cargos nas IAMCs foi financiado com uma drástica redução do salário real. O Salário-Base Médico vigente no mês de março de 1965, atualizado pelo Índice de Preços ao Consumidor e transformado em dólares em setembro de 1992, totaliza US\$1.137; se compararmos com seu valor atual de US\$206, temos uma idéia da magnitude da perda sofrida pelo salário real.

\section{Número de Cargos por Médico}

O sistema de trabalho organizado em torno de cargos com baixa carga horária semanal e a deterioração do salário real explicam a atual situação de multiempregos.

Nos últimos anos, a média de cargos por médico tem se mantido estável. Em 1980 eram 2,7 (Meerhoff, 1988), com a mesma média em 1985 (SMU-FEMI, 1985); em 1990 a média era de 2,5 (SMU, 1990). Essas médias não refletem fielmente a realidade, que registra uma alta concentração de trabaIho.

Detalhando os dados, observamos que, em 1980, $59 \%$ dos médicos ocupavam $32 \%$ dos cargos. Em 1990, 19\% dos médicos concentravam 36\% dos cargos, ao passo que $53 \%$ dos médicos ocupavam $33 \%$ dos cargos.

Em sua pesquisa, Meerhoff estudou a associação entre o número de cargos, a remuneração, o sexo, a idade e a especialização dos profissionais e concluiu que os médicos que mais cargos concentram são os homens entre 
40 e 50 anos e com especialização cirúrgica; obviamente, também concentram a maior parte da remuneração (Meerhoff, 1988).

\section{Remuneração por Médico}

Como conseqüência do multiemprego, a remuneração média do médico não tem origem direta no salário de cada cargo. As informações disponíveis encontram-se na Tabela 6.

\section{TABELA 6}

Distribuição Percentual dos Médicos Segundo Grupos Salariais Uruguai, 1980 e 1990

\begin{tabular}{lcc}
\hline & \multicolumn{2}{c}{ Percentagem de Médicos } \\
Salário em US Doláres & 1980 & 1990 \\
\hline $0-160$ & 18,3 & 14,0 \\
$161-320$ & 18,4 & 19,0 \\
$321-480$ & 11,4 & 15,0 \\
$481-800$ & 19,7 & 19,0 \\
$801-1.200$ & 14,9 & 14,0 \\
1200 e + & 17,3 & 11,0 \\
Sem resposta & - & 8,0 \\
\hline
\end{tabular}

Fonte: Meerhoff, 1988 e sMU, 1990.

No Ministério da Saúde Pública do Uruguai (MSP) existe uma hierarquia de cargos de nove graus. Os três graus inferiores correspondem aos cargos operacionais, os três intermediários a chefias de serviço e os três superiores à direção de hospitais ou unidades. Em todos os casos cumpre-se um horário de 24 horas semanais. Os valores médios das remunerações estão na Tabela 7.

\section{TABELA 7}

Valor Médio dos Salários Segundo os Cargos

Ministério da Saúde Pública do Uruguai, 1991

\begin{tabular}{lc}
\hline Cargos & Valor Médio* \\
\hline Cargos Operacionais & 169 \\
Cargos de Chefia & 210 \\
Cargos de Direção & 261 \\
\hline
\end{tabular}

* em US\$ de junho de 1991. 
No Ministério da Saúde Pública uruguaio, $97 \%$ dos cargos são operacionais, o que significa que a quase totalidade dos médicos daquele órgão ganham, em média, US\$ 169 menssais.

Em outubro de 1991, o conjunto do setor privado destinou cerca de US\$ 6,6 milhões para remunerar o trabalho médico. A média por cargo foi de US\$505.

Dentro do setor privado, o maior empregador foram as IAMCs, que destinaram US\$ 6,4 milhões para o salário médico no mesmo mês, o que significa uma remuneração média por cargo de US $\$ 515$ (SMU-Serra 1992). A remuneração médica apresenta grandes variações, segundo a localização do profissional e a sua especialidade, conforme se verifica na Tabela 8.

TABELA 8

Remuneração Média por Cargo Nas IAMCS por Especialidade

Uruguai, 1991

Em US\$ de 10/91

\begin{tabular}{lrcc}
\hline Especialidade & Interior & Montevidéu & Total \\
\hline Medicina Geral & 893 & 311 & 426 \\
Cirurgia & 967 & 837 & 869 \\
Ginecologia & 1.309 & 401 & 654 \\
Pediatria & 953 & 323 & 443 \\
\hline Total & 943 & 401 & 515 \\
\hline
\end{tabular}

Fonte: SMU-Serra 1992.

Em todo o país, o pagamento por salário fixo representa $50 \%$ do total das remunerações, o pagamento por serviço prestado representa $17 \%$, as compensações perfazem $15 \%$ e outras modalidades, $17 \%$.

Nesta análise ficam evidentes algumas tendências comuns a outros países, que podem ser resumidas em:

- Aumento geométrico da taxa de médicos para cada 10.000 habitantes.

- Concentração dos recursos médicos na capital.

- Feminização da população médica.

- Aumento da especialização e da multiespecialização.

Concomitantemente, e em parte como conseqüência desses processos, produziram-se mudanças nas práticas de trabalho dos médicos, a saber:

- A deterioração das condições de emprego do médico: diminuição do salário real, aumento das taxas de desemprego e subemprego. 
- A consolidação do multiemprego como forma de aumentar a renda e o grau de autonomia profissional.

- A altíssima capacidade que os médicos tiveram de expandir a demanda conjuntamente com a oferta evitou que o desemprego e a redução da renda per capita chegasse aos extremos que a manifesta superoferta poderia provocar.

- A adoção de estratégias individuais de diversificação de postos de trabatho com base na acumulação de cargos, e a posse de várias especialidades simultaneamente, para melhorar a renda.

Num mercado livre, o preço de um bem ou serviço surge da interação da demanda por parte dos consumidores com a oferta por parte do setor produtivo. Os preços se formam no mercado quando a demanda e a oferta se encontram. $O$ mercado age como um mecanismo distribuidor e fixador de recursos, estimulando ou deprimindo a produção. $O$ mercado de trabalho do pessoal da saúde não é regido por essas leis. Entre suas principais características, algumas se destacam, a saber:

- No mercado médico, a demanda é regida apenas parcialmente pela vontade do consumidor (o paciente ou a instituição de assistência médica); os próprios produtores (os médicos), graças ao seu conhecimento especializado, determinam, em grande parte, o tipo e a medida do serviço a ser prestado. Um indicador dessa capacidade que a oferta possui de induzir a demanda é, como já vimos, o grande incremento no número de cargos disponiveis com base na pluriespecialização e na diferenciação de serviços.

- É marcante o papel social dos profissionais de saúde, revestido de um significado cultural que torna certas profissões desejáveis e alvo do apoio público independentemente de sua real demanda.

- A ação corporativista das diversas categorias situa o salário num nível superior ao de um salário estritamente determinado pelas leis do mercado.

\section{ODONTÓLOGOS}

\section{Formação}

A Faculdade de Odontologia é a responsável pela formação de profissionais e outorga o título de "Doutor em Odontologia".

O curso universitário tem duração curricular de cinco anos. Os programas atuais priorizam aspectos vinculados à odontologia social nos cursos regulares.

Em 1991, o número de matriculados chegou a 3.204. O número de diplomados mantém-se praticamente estável nos últimos anos (cerca de 130), com franco predomínio feminino. 


\section{Aspectos Demográficos e de Mercado de Trabalho}

Em 1985, o país contava com 2.723 odontólogos - um profissional para cada 1.977 habitantes. A distribuição geográfica de odontólogos é de 1 para cada 673 habitantes em Montevidéu e um para cada 2.917 no interior do país (Tabela 9).

\section{TABELA 9}

Distribuição Geográfica de Odontólogos

Uruguai, 1985

\begin{tabular}{lccc}
\hline & Montevidéu & Interior & Total do país \\
\hline Número de Profissionais & 2723 & 789 & 3512 \\
Taxa por 10.000 habitantes & 20,11 & 4,53 & 11,35 \\
\hline
\end{tabular}

Fonte: Caja de Profesionales Universitarios.

Informes normativos de metas de pessoal de saúde para as Américas propõem, como taxa desejável para odontólogos, três profissionais para cada dez mil habitantes (OPAS, 1973). Comparando esta taxa com as existentes, observa-se uma superoferta de profissionais em Montevidéu e uma situação mais equilibrada no interior.

Não existem informações consolidadas sobre o mercado de empregos em Odontologia, pois as atividades odontológicas estão excluídas, em geral, das prestações de serviço do Ministério da Saúde Pública e dos seguros prépagos (salvo as ações preventivas e as de emergência). Isso faz com que exista ainda um amplo desenvolvimento da prática autônoma e, por outro lado, uma baixa cobertura da população, apesar dos estudos epidemiológicos que mostram a alta prevalência de patologias orais.

\section{ENFERMAGEM}

\section{Formação}

As Escolas Universitárias (que se diferenciam das Faculdades por serem formadoras de técnicos do nível médio) ligadas ao setor saúde são sete: Escola de Tecnologia Médica, Escola de Enfermagem, Escola de Nutrição e Dietética, Escola de Parteiras, Escola de Auxiliares de Odontologia, Instituto de Psicologia e Serviço Social.

As quatro primeiras pertencem ao domínio da Faculdade de Medicina; a quinta, à Faculdade de Odontologia; as duas últimas, à Reitoria da Universidade. Os diplomados nas Escolas Universitárias recebem o título de profissional de nível intermediário, e antigamente eram denominados, em alguns casos, auxiliares ou colaboradores. A carga curricular desses cursos oscila entre 2 e 5 anos. 
Segundo dados da División Estadistica da Dirección General de Planeamiento Universitario para 1989, o total de diplomados nas Escolas Universitárias ligadas à saúde chegou a $22 \%$ do total de diplomados de nível superior de educação em todo o país. Em números absolutos, 721 formados de um total de 3.203.

\begin{tabular}{lr}
\multicolumn{2}{c}{ TABELA 10 } \\
$\begin{array}{l}\text { Diplomados em Escolas Universitárias } \\
\text { Uruguai, 1989 }\end{array}$ \\
\hline Tecnologia Médica & 215 \\
Psicologia & 188 \\
Aux. Odontologia & 136 \\
Enf. Universitária & 99 \\
Serviço Social & 57 \\
Nutrição & 24 \\
Parteiras & 2 \\
\hline
\end{tabular}

\section{a) Escuela Universitaria de Enfermagem}

Formou Enfermeiras Universitárias até 1974, ano em que foi determinada a sua fusão funcional com a Escuela Dr. Carlos Nery, dependente do Ministério da Saúde Pública, tendo retornado à esfera universitária em 1985.

O Uruguai, como a maioria dos países latino-americanos, possui pequeno número de enfermeiros profissionais, problema agravado particularmente pela migração para países com maior desenvolvimento econômico-social.

A extensão curricular da Licenciatura em Enfermagem é de cinco anos, não existindo subespecializações.

Calcula-se em 1.700 o número de enfermeiras universitárias graduadas (uma para cada 1.700 habitantes), das quais somente $8 \%$ estão radicadas no interior do país.

b) Escuela de Sanidad

Criada por Lei Orgânica do Ministério da Saúde Pública em 1934, é a única instituição docente do MSP que forma pessoal de nível intermediário (não universitário). Os cursos têm lugar em Montevidéu e no interior do país.

A formação mais importante corresponde às auxiliares de enfermagem, com carga curricular de 16 meses. Além disso, a Escola forma 12 diferentes tipos de auxiliares de saúde.

Durante o último ano, essa instituição começou a desenvolver uma Licenciatura em Enfermagem, com duração de quatro anos e um semestre, 
exigindo nível secundário de educação e a formação prévia de Auxiliar de Enfermagem com dez anos de experiência prática.

\section{Demografia e Mercado de Trabalho (Tabela 11)}

Informes normativos de metas para pessoal de saúde na área das Américas estabelecem, como taxa desejável para Enfermeiras Profissionais, 4,5 para cada 10.000 habitantes (OPAS, 1973). Comparando essa taxa com as existentes, vemos que a oferta global de enfermeiras é adequada, embora exista uma péssima distribuição entre Montevidéu e o interior do país.

\section{TABELA 11}

Distribuição Geográfica de Pessoal de Enfermagem

Uruguai

\begin{tabular}{lrrrrrrr}
\hline & \multicolumn{2}{c}{ Montevidéu } & \multicolumn{2}{c}{ Interior } & \multicolumn{2}{c}{ Total do País } \\
\cline { 2 - 7 } Profissão & Número & Taxa $^{*}$ & Número & Taxa* & Número & Taxa \\
\hline Parteiras & 380 & 2,81 & 229 & 1,32 & 609 & 1,97 \\
Enf. Universitárias & 1.452 & 10,72 & 258 & 1,48 & 1.710 & 5,53 \\
\hline
\end{tabular}

Fonte: Caja de Profesionales Universitarios.

* Taxa por 10.000 habitantes.

Não existem dados confiáveis sobre o número e a distribuição de auxiliares de enfermagem, embora os cálculos da Divisão de Planificação do Ministério da Saúde Pública coloquem esse número em torno de 15.000 , isto é, cerca de 10 auxiliares para cada enfermeira profissional e 50 para cada 10.000 habitantes.

O pessoal de Enfermagem Profissional tem alta demanda no mercado de trabalho, embora em geral não consiga acompanhar essa demanda com níveis salariais adequados, devido à estrutura de representação corporativa da profissão, vinculada ao resto de profissionais não-médicos através da $\mathrm{Fe}$ deración Uruguaya de Salud (FUS).

A fus agrupa cerca de 18.000 profissionais e funciona desde 1967 . Organiza-se por empresa: seus sindicatos de base abrangem os funcionários das diversas profissões em cada instituição. Essa heterogeneidade se reflete nas dificuldades de unificação das reivindicações de setores diferentes - por exemplo, as reivindicações das enfermeiras profissionais com as de Auxiliares de Serviço, as primeiras de alta demanda e baixa oferta, e as segundas, em condições inversas. Essa situação contribui para a depreciação da mãode-obra da Enfermagem em geral, e em particular de seu setor profissional. 


\section{QUADRO LEGAL E ÉTICO DO EXERCÍCIO DE PROFISSÕES DE SAÚdE NO URUGUAI}

No Uruguai, para que o profissional de saúde possa exercer sua profissão é necessário, em primeira instância, obter um título acadêmico no país ou revalidado no mesmo.

Uma vez obtido, o diploma deve ser registrado no Ministério da Saúde Pública através de seu Departamento de Coordenação e Controle, ficando o profissional habilitado ao exercício da profissão em todo o território uruguaio. Além disso, o Ministério outorga uma carteira de habilitação profissional.

Declarando-se ou não o exercício privado da profissão, o profissional deve também realizar o registro correspondente na Caja de Jubilaciones Profesionales.

A Lei Orgânica de 1934, que criou o Ministério da Saúde, previa uma estrutura denominada Comisión Honoraria de Salud Pública, formada, segundo reza a lei, "por pessoas respeitáveis, encarregadas da supervisão das profissões de Saúde", isto é, do controle dos aspectos éticos - na realidade, um tribunal de ética em saúde organizado pelo próprio Estado. Essa estrutura vigora até hoje.

No início de 1992, o Ministério da Saúde Pública colocou em estudos um projeto de Decreto do Poder Executivo versando sobre regras de conduta médica e direitos dos pacientes, projeto duramente questionado pelas associações de classe da área médica.

No entanto, a criação desse colegiado e a aplicação de um Código de Ética que atue como regulador e controlador da atividade profissional constituem, para os médicos e outros profissionais da saúde, uma antiga aspiração que até hoje, por motivos diversos, não chegou a concretizar-se.

O Sindicato Médico do Uruguai teve participação decisiva na redação de um anteprojeto que em 1988 foi apresentado para estudos à Comissão correspondente no Parlamento uruguaio e que sugeria a instauração do Colegiado de Médicos como "pessoa jurídica pública, não estatal, encarregada de assegurar a independência profissional dos médicos e o controle de sua atividade moral". Esse órgão ditaria normas de comportamento profissional e seria o responsável pela resolução de problemas de ética e de deontologia.

Não existem instâncias ou projetos de estruturas de regulamentação ética ou deontológica das categorias restantes, além da que possa ser realizada por suas associações de classe. 


\section{BIBLIOGRAFIA}

Caja de Jubilaciones de Profesionales Universitarios del Uruguay. Boletines Informativos.

Dirección General de Estadísticas y Censos: /l Censo Económico Nacional. Tabulaciones no publicadas. Uruguay, 1979.

Dirección General de Estadísticas y Censos: III Censo Económico Nacional. Fase I. Uruguay, 1988.

Meerhoff, R.: El mercado de trabajo médico en el Uruguay. Oficina de Planeamiento y Presupuesto, Presidencia de la República, Montevideo, marzo de 1988. 191 p.

Meerhoff, R.: Investigación en personal de salud. Egresados de la Facultad de Medicina de la Universidad de la República, Uruguay. Ed. Med. Salud, vol. $21 \mathrm{n}^{\circ} 3,1987$.

OPS/OMS: Recomendaciones y metas del Plan Decenal de Salud para las Américas 1971 - 1980. Reseñas Ed. Med. Salud, vol. 7, nº 3 - 4, 1973.

Rial, J.: Salud Pública y clases subalternas en Montevideo a fines del siglo XIX y comienzos del XX. CIESU, DT/43/83. Uruguay, 1983.

Rígoli, F.: Recursos Humanos en el Sector Salud del Uruguay. Proyecto SISALUD-CERES, Centro Internacional de Investigaciones para el Desarrollo, Mimeo, Montevideo, 1991.

Schonfeld $H$. K.: Number of phisicians required for primary medical care. New England Journal of Medicine. 286 (3): 571-576.

SMU (Sindicato Médico del Uruguay): Censo Médico Nacional. Acción Sindical, no 93, Nov.-Dic., 1963.

SMU (Sindicato Médico del Uruguay) - FEMI (Federación Médica del Interior): Investigación sobre la situación profesional, ocupacional y social de los médicos en el Uruguay. Equipos Consultores Asociados, Set. de 1985. (Mimeo).

SMU (Sindicato Médico del Uruguay): Encuesta Médica Nacional, Informe Final. AlM Burke, Montevideo, Octubre de 1990. (Mimeo).

SMU (Sindicato Médico del Uruguay) - Serra, J.: Estudios preliminares para la negociación salarial. Montevideo, 1992. (Mimeo).

Yanicelli, E.: Información básica sobre estructura sanitaria y seguros de salud en el Uruguay. Sindicato Médico del Uruguay. Marzo de 1974. (Mimeo). 



\title{
ParaguaI: SituaÇÃo da FORMAÇÃO E MERCADO DE TRABALHO NA ÁREA DA SAÚDE
}

\author{
Alicia Arnau \\ Célia Regina Pierantoni
}

\section{INTRODUÇÃo}

O Paraguai, como todos os países da América Latina, enfrenta uma crise de transição do seu modelo de saúde. É um país eminentemente jovem, onde quase $50 \%$ da população tem menos de 15 anos, com altos índices de natalidade e fertilidade, elevadas taxas de mortalidade infantil, com uma importante população rural ( $54 \%$ da população total) e com significativa proporção vivendo em comunidades espalhadas e com dificuldades de comunicação.

O Ministério de Saúde Pública e Bem-Estar Social (MSPBS) enuncia, em seu discurso, a prioridade nas ações de promoção e prevenção em saúde; no entanto, a maior parte de seus recursos financeiros e humanos são alocados na prestação de serviços assistenciais. Para isto, conta com unidades assistenciais de diferentes níveis de complexidade em todo o território nacional.

Há dois anos, aproximadamente, está em debate o tema da descentralização, provocando situações de reacomodação orgânica e funcional nos níveis central e regional. Os serviços de saúde encontram-se em processo de reorganização, com o desenvolvimento de iniciativas que visam a normatiza- 
ção da assistência, estabelecendo os tipos e a natureza dos serviços, bem como a definição de perfis ocupacionais.

Neste período de transição democrática é notória a intencionalidade política de fortalecer a assistência através da Rede Nacional de Saúde, enfrentando-se, no entanto, com limitações importantes, tanto para a alocação de recursos, como na capacidade técnica, que permitiria a implementação desta vontade de mudança.

Envolvido num contexto de descentralização sobredimencionado burocraticamente, com limitações financeiras e técnicas, o sistema de saúde apresenta dois níveis estratégicos de gestão: um nível central, com limitações técnicas para realizar o processo de reforma estrutural; e um nível regional, composto de quinze regiões sanitárias, que realizam a prestação de serviços através de hospitais de terceiro, quarto e quinto nível, junto com os centros e postos de saúde.

Nos programas e subprogramas é nítida a atribuição da função de condução a médicos e das funções operativas a outros profissionais, como a enfermeira. Ao médico atribui-se, além do seu papel clássico de diagnóstico e terapêutica, também o gerenciamento das instituições; à licenciada em enfermagem, as tarefas de condução, capacitação de auxiliares e de supervisão regional; e ao pessoal auxiliar, grupo de baixo nível educativo e de estrato social pobre, os serviços de auxiliar de enfermagem e atividades gerais (limpeza etc.).

Embora tenham sido implementados cursos de Saúde Pública e Administração de Serviços, há carência de pessoal capacitado para a função de condução.

O MSPBS considera a capacitação como uma estratégia básica para a mudança no modelo assistencial. Com a cooperação da OPS/OMS, foi analisado o modelo de capacitação utilizado, tendo ficado demonstrado que este se realizava de forma episódica, com base nas necessidades do nível central. O estudo permitiu, ainda, que a capacitação seja reorientada segundo os princípios da educação permanente, cujo desenvolvimento na rede de serviços é até agora incipiente.

O Ministério incorpora tecnologia de acordo com os níveis de complexidade, da básica a avançada, sem avaliação prévia, o que conduz a uma incorporação acrítica, incompleta e com déficits na sua manutenção técnica.

Na Previdência Social (PS), observa-se uma estrutura organizacional e funcional caracterizada pelos níveis central e regional, ambos desenvolvendo um trabalho cooperativo entre as unidades de saúde, independente do seu grau de complexidade.

Embora a PS tenha se mantido historicamente isolada, no período democrático atual verificam-se assinaturas e desenvolvimento de acordos de cooperação com outras instituições prestadoras de serviços e formadoras de recursos humanos em saúde. 
Para o desenvolvimento e aplicação progressiva da política desenhada pelo Conselho Nacional de Saúde, estabeleceram-se estratégias de ação, com diferentes componentes programáticos.

Isto inclui linha de cooperação interinstitucional no campo da assistência médica, capacitação de pessoal e desenvolvimento de projetos de pesquisa. O objetivo deste empreendimento é obter maior eqüidade entre os diferentes prestadores - logrando, assim, uma cobertura assistencial mais eficiente -, fortalecer os serviços de assistência médica e melhorar a produção médico-cirúrgico e laboratorial.

O Hospital das Forças Armadas estabelece cooperação com outras unidades que também pertencem à Saúde Militar, bem como com outras instituições assistenciais e de formação.

A divisão de trabalho apresenta dois níveis de segmentação: de um lado, o determinado pela hierarquia militar e, por outro, a hegemonia no setor de condução da gestão médica. Possui sistema de capacitação permanente em serviço para o grupo de assistência, enquanto o grupo de gestão capacita-se fora do hospital.

Tanto o grupo de gestão, quanto o de assistência, tem a preocupação com a organização de um novo hospital, tendo em conta que os orçamentos não têm incluído financiamento para recursos humanos e tecnologia.

No Hospital Policial ocorre, da mesma forma, a dupla segmentação que referimos para o Hospital das FFAA: pela hierarquia policial e pela hegemonia médica. Deve-se assinalar, contudo, que as organizações assistencial e administrativa são incipientes, embora se estejam criando novas unidades de prestação de serviços.

O Hospital das Clínicas, por sua vez, iniciou recentemente a centralização da administração dos recursos financeiros oriundos do pagamentos por serviços prestados. As diferentes cátedras apresentam, historicamente, a característica de "feudos", com seus próprios sistemas assistencial, financeiro, administrativo e docente. Está em curso um diálogo para a mudança entre os diversos setores, apesar da resistência apresentada principalmente pelos professores mais antigos.

A Cruz Vermelha Paraguaia criou o primeiro Manual de Normas e Procedimentos da instituição, que inclui tanto o pessoal de assistência quanto de administração e de serviços.

Nas instituições privadas o modelo organizacional é diversificado e expressa a forma específica que adquire, em cada uma, o relacionamento entre os usuários e os profissionais.

Assim, no setor privado de pré-pagamento, a escolha dos profissionais pelos usuários fica restrita àqueles que figuram na relação da empresa, segundo o tipo e a natureza dos serviços (especialidades) que prestam.

$\mathrm{Na}$ medicina privada, a cooperação entre os médicos ocorre de diferentes formas. Um exemplo é o do profissional de maior prestígio, que esta- 
belece, informalmente, um sistema de complementariedade com outros especialistas na prestação de serviços, pois é acompanhado de uma equipe de trabalho constituída de ajudantes, anestesistas, pediatras etc.

Embora estas empresas não tenham se envolvido na capacitação profissional, atualmente estão se estabelecendo, na área privada, residências em subespecialidades (casos dos sanatórios Bautista e Mignone).

\section{MERCADO DE TRABALHO}

O número de profissionais que cada instituição emprega tem relação direta com a cobertura que oferece. Assim, o maior empregador de profissionais de saúde é o Ministério de Saúde Pública e Bem-Estar Social, que atende cerca de $65 \%$ da população. Em seguida, em ordem decrescente, encontram-se a Previdência Social, que se encarrega dos assalariados do país, com uma cobertura de $16 \%$ do total; a Previdência Militar, que assiste aos militares e suas famílias e atua nas emergências nacionais, oferecendo uma cobertura de 10\%; o Hospital de Clínicas, entidade docente de graduação e pós-graduação da Universidade Nacional de Assunção, que atende a $2 \%$ da população, e outras instituições menores e as empresas particulares de atenção que se encarregam de $7 \%$ da cobertura total.

Número de Cargos Oferecidos pelo Ministério de Saúde Pública e Bem-Estar Social

\begin{tabular}{lrrrr}
\hline Categorias & Regiões & Hosp. Esp. & Central & Total \\
& & & & \\
Médicos & 762 & 786 & 56 & 1.607 \\
Odontólogos & 200 & 36 & 3 & 239 \\
Químicos & 60 & 102 & 11 & 173 \\
Lic. Enf. e Obst. & 441 & 100 & 17 & 588 \\
Aux. em Saúde & 1.586 & 493 & 24 & 2.103 \\
Aux. Obst. Rural & 204 & 2 & - & 206 \\
\hline
\end{tabular}

Fonte: OPAS. 


\section{Número de Cargos Oferecidos pelo Instituto de Previdência Social}

\begin{tabular}{lrrr}
\hline Categorias & Central & Regional & Total \\
\hline Médicos & 611 & 262 & 873 \\
Odontólogos & 92 & 51 & 143 \\
Químicos & 93 & 14 & 107 \\
Lic. Enf. e Obst. & 132 & 26 & 159 \\
Técnicos & 148 & 167 & 315 \\
Auxiliares & 1.056 & 460 & 1.516 \\
\hline
\end{tabular}

Fonte: OPAS.

Número de Cargos Oferecidos por Outras Instituições Paraguaias

\begin{tabular}{lcccc}
\hline Categorias & $\begin{array}{c}\text { Hospital de } \\
\text { Clínicas } \\
\text { (U.N.A.) }\end{array}$ & $\begin{array}{c}\text { Previdência } \\
\text { Militar }\end{array}$ & $\begin{array}{c}\text { Previdência } \\
\text { Policial }\end{array}$ & $\begin{array}{c}\text { Cruz } \\
\text { Vermelha } \\
\text { Paraguaia }\end{array}$ \\
\hline Médicos & 820 & 102 & 123 & 82 \\
Odontólogos & 6 & 38 & 38 & 2 \\
Químicos & 44 & 28 & 16 & 9 \\
Lic. Enf. e Obst. & 118 & 13 & 12 & 23 \\
Técnicos & 41 & 15 & 23 & 9 \\
Auxiliares & 308 & 117 & 37 & 89 \\
\hline
\end{tabular}

Fonte: OPAS.

Estas instituições apresentam várias características em comum, bem como particularidades em relação ao sistema de admissão, contratação e remuneração dos funcionários.

Os critérios utilizados para fixar o montante salarial no setor público e na Previdência Social estão fortemente condicionados por critérios estabelecidos pelo Ministério da Fazenda, com um teto orçamentário para cada categoria. Esta situação denota a falta de normas de classificação de cargos que levem em conta as funções, atividades e responsabilidades dos trabalhado- 
res em saúde. $A$ isso soma-se a falta de uma relação hierárquica que defina claramente as regras do jogo entre empregador e empregado.

O salário abrange diferentes vínculos empregatícios, com a mesma modalidade empregada tanto para o pessoal permanente quanto para o interino contratado.

A forma de remuneração através do pagamento por tempo ou salário é a única utilizada pelas previdências públicas (Ministério da Saúde, Hospital de Clínicas, FFAA, IPS etc). As outras modalidades de previdência privada e seguros de saúde adotam uma forma de contratação mista: além do tempo, paga-se também por produtividade.

Existem, em algumas instituições, certas formas de incentivo - Categorias monetário ou não - algumas das quais são mencionadas a seguir.

Na Previdência Social, no início de cada ano escolar, é feita a entrega do $14^{\circ}$ salário aos funcionários, como incentivo e apoio à escolarização dos filhos. Também é usual, nas instituições do setor, o fornecimento de automóveis e combustivel aos funcionários dos escalões superiores.

No Hospital Nacional (Ministério da Saúde), um hospital de grande complexidade situado a $36 \mathrm{Km}$ da capital, além do fornecimento de veículos e combustivel ao pessoal dos escalöes superiores, abona-se meia passagem do transporte de todos os funcionários.

Até o início do ano de 1994, o pessoal das Forças Armadas, assim como o da Polícia, recebia um complemento salarial correspondente a uma refeição para o funcionário e sua família; esse complemento variava segundo o número de integrantes de cada núcleo. Atualmente, esse tipo de incentivo foi substituído por uma remuneração monetária extra-salarial, que varia segundo a família de cada funcionário.

Outras instituições, como o Hospital de Clínicas e a Cruz Vermelha Paraguaia, não oferecem qualquer tipo de estímulo. No entanto, parece-nos importante destacar que nenhum funcionário da Cruz Vermelha Paraguaia recebe um salário menor do que o mínimo estabelecido pelo governo paraguaio.

Nas instituições particulares de pré-pagamento existem sistemas de incentivos monetários, com o pagamento de prêmios a determinados profissionais por boa atuação, no final de cada ano; esses e outros métodos de apoio ao funcionário não são padronizados, e fazem parte de acordos informais entre empregadores e empregados.

E importante observar que o Censo Nacional de 1993 permitiu determinar os dados relativos ao número de profissionais das categorias aqui focalizadas atuando em Assunção, a saber: 


\begin{tabular}{lrrr}
\hline Categorias & Central & Regional & Total \\
\hline Médicos & 1.242 & 642 & 1.884 \\
Cirurgiões & 202 & 82 & 284 \\
Odontólogos & 232 & 393 & 625 \\
Técnicos & 202 & 234 & 436 \\
Fisioterapeutas & 31 & 90 & 121 \\
Lic. Enf. e Obst. & 90 & 773 & 836 \\
Auxiliares & 133 & 1.177 & 1.310 \\
\hline Total & 2.132 & 3.391 & 5.523 \\
\hline
\end{tabular}

Fonte: OPAS.

\section{SISTEMA FORMADOR E SUAS INSTITUIÇÕES}

\section{Medicina}

No Paraguai, a formação de médicos está a cargo de duas escolas de Medicina: Faculdade de Ciências Médicas da Universidade Nacional de Assunção e Faculdade de Medicina de Villarrica da Universidade Católica Nossa Senhora de Assunção.

No período compreendido entre 1980 e 1992, observa-se uma diminuição importante do número de matriculados no primeiro ano (taxa de crescimento de 0,079 em um periodo de 13 anos). Conseqüentemente, o número de matrículas totais diminuiu (com uma tendência estável e levemente decrescente).

Em 1980 egressaram 110 homens (62\%) e 65 mulheres (38\%), e em 1991 titularam-se 67 homens (58\%) e 49 mulheres (42\%), ou seja, um leve aumento na proporção de mulheres (4\%) em 12 anos.

\section{Faculdade de Clênclas Médicas (UNA)}

A FCM/UNA, centenária casa de estudos, iniciou suas atividades no ano de 1889 e, desde então, tem formado numerosas turmas de médicos.

$O$ ingresso de alunos à $F M C / U N A$ é feito logo após a conclusão da educação secundária, mediante a apresentação dos documentos requeridos para a inscrição ao exame de ingresso preparado pela unidade docente. Os exames de admissão, e tudo o que diz respeito a eles, estão a cargo do Comitê de Admissão da Faculdade.

O exame de admissão é obrigatório e tem vagas limitadas, estabelecidas pelo Conselho Universitário Superior; consiste em perguntas sobre Ma- 
temática, Física, Química e Biologia, sendo utilizada a metodologia da múltipla escolha. As provas são corrigidas pelo Conselho de Admissão, que envia ao Conselho Diretor da Faculdade os resultados e os currículos escolares. $\mathrm{O}$ Conselho Diretor elabora o relatório final e o remete ao Conselho Universitário Superior, para homologação.

O curso tem duração de seis anos, findos os quais a FMC outorga um certificado de conclusão. $O$ aluno apresenta esse Certificado de Estudos à Reitoria da UNA, para que esta possa expedir o Diploma de Estudos que o habilita como Médico-Cirurgião.

O Conselho Diretor da FMC, através de Resolução de 1989, estabeleceu a obrigatoriedade de um período rotativo como médico-interno; na prática, porém, isso não é cumprido, tendo se transformado numa opção pessoal e de pós-graduação, condição indispensável somente para os que desejam realizar uma carreira docente.

As razões que levaram a isso são numerosas, e entre elas estão as enormes dificuldades orçamentárias da Faculdade, que não tem condições para pagar salários a todos os alunos durante seu período de internato. Devemos também ter em conta a pressão das associações estudantis dos alunos, que desejam ingressar no mercado de trabalho imediatamente ou iniciar a formação nas residências médicas.

Os programas de estudos vêm sofrendo leves variações; há alguns anos, foram incluídas matérias sobre saúde pública e houve uma certa intenção de acesso a um discurso de caráter mais social, que não teve continuidade.

A formação segue um modelo biológico, embora insista-se na qualidade da relação médico-paciente; no entanto, o número elevado de doentes e a escassez de recursos disponíveis tornam muito difícil o acesso dos estudantes a ações comunitárias ou à análise dos componentes emocionais e sócioambientais da assistência.

Na graduação, a Faculdade de Ciências Médicas é encarregada da concepção, elaboração e avaliação dos cursos. O espaço de prática e aprendizado dos alunos limita-se às aulas e ao Hospital de Clínicas, que é o órgão assistencial da Faculdade.

\section{Faculdade de Medicina de Villarrica (UCA)}

A Faculdade de Medicina de Villarrica (UCA) encontra-se a $200 \mathrm{~km}$ da Capital. Foi criada na área rural do país para oferecer aos jovens do interior condições de seguirem a carreira médica, com ênfase na Medicina Rural. Foi reconhecida pelo Poder Executivo em 1989, tendo seus currículos homologados com os da Faculdade de Ciências Médicas da UNA, sem no entanto perder a identidade de um programa próprio da Universidade Católica. Essa homologação permitiu a rotação dos alunos nos programas do Hospital de 
Clínicas da FCM. Do corpo docente, $80 \%$ vêm da FCM/UNA e $20 \%$ são profissionais locais.

O currículo da Faculdade de Medicina de Villarrica prevê seis anos de estudos, com as práticas assistenciais sendo realizadas no Hospital Espírito Santo, órgão assistencial da Universidade Católica. Finalizada a programação estabelecida, a Reitoria da UCA expede o Diploma de Médico Cirurgião.

\section{Pós-Graduação}

Segundo os estatutos da $\mathrm{FCM}$, o internato rotativo corresponde a graduação, embora, na prática, tenha se transformado em pós-graduação com as características opcionais. Os estudantes que desejam continuar uma residência dentro da FCM ou continuar a carreira docente universitária no âmbito da mesma faculdade são os que cumprem o internato rotativo.

As instituições públicas e privadas e da Seguridade Social realizam um trabalho de capacitação, oferecendo residências médicas nas diferentes especializações; por isso, diante da falta de coordenação das atividades, o Conselho Nacional de Saúde encarregou seu Comitê de Recursos Humanos, presidido pelo Decano da Faculdade de Ciências Médicas, da análise e regulamentação do setor. Durante dois anos as instituições formadoras e prestadoras de serviços reuniram-se, resultando daí um Programa Nacional de Residências Médicas, com um anteprojeto de lei que aguarda envio ao Parlamento Nacional.

A pós-graduação, em nível nacional, ficou reduzida às residências médicas e à busca de serviços especializados, pois inexistem escolas de pós-graduação e escolas de graduação que emitam certificados de especialização.

\section{Odontologia}

A Faculdade de Odontologia da UNA foi criada em 1938. As condições de admissão e o regulamento interno da faculdade são similares ao descrito no texto relativo à Faculadade de Ciências Médicas.

O curso tem a duração de cinco anos, ao término dos quais emite-se um Certificado de Estudos que permite ao aluno iniciar os trâmites junto à Reitoria da UNA, que o habilita ao exercício profissional mediante o Diploma de Doutor em Odontologia.

A Faculdade forma profissionais não-especializados, com condições de desempenhar adequadamente a prática cotidiana. Trata-se de uma faculdade eminentemente manual - o trabalho é aprendido através da prática contínua e supervisionada. É importante destacar que o número cada vez maior de pacientes, assim como o instrumental escasso e ultrapassado, criam a realidade que enfrentam tanto os estudantes quanto os profissionais docentes; apesar disso, os profissionais diplomados contam com boa inserção no mercado de trabalho nacional. 
Há um debate corrente sobre a inclusão de mais um ano no currículo, por haver excesso de horas de trabalho em alguns anos. Essa inclusão possibilitaria a existência de um internato rotativo, com passagem pelo interior do país.

A Faculdade de Odontologia da UNA era a única formadora de odontólogos até o ano de 1992, quando foi criada uma faculdade particular, no âmbito do Círculo Paraguaio de Odontólggos (gremial-científico).

Em referência ao número de matrículas no primeiro ano, observa-se uma tendência estável e levemente crescente desde 1983. A taxa de crescimento entre 1980 e 1992 foi de $6 \%$. A taxa de crescimento de formados é de 0,026 . Estudo realizado recentemente mostra que os matriculados no primeirọ ano provêm da classe média, são comerciantes etc., em geral de áreas urbano-metropolitanas. A feminização é outro traço dominante nesta profissão.

\section{Pós-Graduação}

A formação de pós-graduação em Odontologia é realizada a partir de prática, em cursos particulares de atualização ou cursos de especialização no exterior.

\section{Farmácia e Bioquímica}

A Faculdade de Bioquímica da UNA foi fundada em 1949. As condições de admissão e o regulamento interno da Faculdade são similares aos descritos no texto correspondente à $\mathrm{FCM}$.

O curso tem a duração de seis anos, ao término dos quais emite-se um Certificado de Estudos que permite ao aluno iniciar os trâmites junto à Reitoria da UNA, que o habilita ao exercício profissional mediante o Diploma de Doutor em Bioquímica. Essa Faculdade forma profissionais práticos, com boa inserção no mercado profissional.

As Faculdades de Química e Farmácia da UCA encontram-se no interior do país - uma em Villarrica, a $200 \mathrm{~km}$ da Capital, e a outra, na Ciudad del Este, a $328 \mathrm{~km}$ da Capital. Em ambas, o curso tem a duração total de cinco anos, findos os quais a UCA expede o Diploma de Químico Farmacêutico.

\section{Pós-Graduação}

A formação de pós-graduação em Bioquímica se realiza a partir da prática, em cursos particulares de atualização ou cursos de especialização no exterior. 


\section{Licenciatura em Enfermagem}

\section{Escola Andres Barbero}

A Escola foi criada em 1939 pelo Ministério de Saúde Pública e Bem-Estar Social sob o nome de Escola de Visitadores de Higiene. No ano de 1941, recebeu o nome de Escola Polivalente de Visitadores de Higiene, formando enfermeiros hospitalares, obstetras rurais e nutricionistas. Em 1952 estabeleceu-se a Licenciatura em Enfermagem, Obstetricia e Serviço Social, e em 1964 a Escola foi incorporada à Universidade Nacional de Assunção. Entre 1984 e 1991, a Enfermagem desvinculou-se da Obstetrícia, com a conseqüente diversificação dos currículos; atualmente ela é subordinada à Faculdade de Ciências Médicas da UNA.

O procedimento de admissão é similar ao de outras instituições da Universidade Nacional de Assunção. Os cursos de Enfermagem e Obstetrícia têm duração de cinco anos. A análise de seu processo histórico permite-nos observar que o número de diplomados em Enfermagem decresce entre 1980 e 1985, em parte por causa da divisão das carreiras, mas sobretudo porque a Obstetrícia goza de melhor inserção no mercado de trabalho, assim como de maior autonomia profissional. De 1986 a 1992, essa tendência mostra-se estável, embora errática.

\section{Licenciatura em Enfermagem e Obstetricia}

A Universidade Católica Nossa Senhora da Assunção possui unidades formadoras em Assunção, Encarnação e Villarrica.

$O$ ingresso a essas unidades é feito a partir do sistema estabelecido pela UCA. Os alunos, em sua maioria, são jovens do interior. O curso tem duração de cinco anos, ao cabo dos quais o aluno recebe o título de graduado em Enfermagem e Obstetricia.

\section{Pós-Graduação}

A Universidade Católica possui a Escola de Pós-Graduação em Enfermagem. A capacitação em serviços é o mecanismo habitual de formação, salvo nos casos de alunos que buscaram especializações formais no estrangeiro.

\section{Pessoal Auxiliar}

A formação de auxiliares compete ao Ministério de Saúde Pública e Bem Estar Social, através do Centro de Formação de Auxiliares de Enfermagem e de Auxiliares em Obstetrícia Rural. 
Somam-se a esta formação instituições de serviços, como o Hospital de Clínicas e as Secções Coloradas (políticas). Estas últimas estão sendo regulamentadas pelo Ministério da Saúde, exigindo-se o cumprimento de requisitos básicos para a formação. A tendência dos auxiliares de enfermagem formados é levemente decrescente desde 1980.

\section{Planejamento Educacional}

O planejamento educacional vem ocorrendo historicamente de forma separada entre as instituições formadoras e utilizadoras, em especial o MSPBS.

$\mathrm{Na}$ gestão atual, as autoridades universitárias e do Ministério chegaram a um acordo de trabalhar conjuntamente na área de recursos humanos em saúde. Como resultado deste acordo, desenvolveram-se programas e ações de capacitação em nível de pós-graduação (saúde pública, materno-infantil etc.).

Na graduação, apesar do entendimento comum da necessidade de meIhorar o processo de articulação, não foram obtidos avanços importantes, exceto no caso do projeto da XIII Região Sanitária, financiado pelo Fundação Kellogg.

A cooperação técnica da OPS contribuiu para que algumas Escolas (Enfermagem, Auxiliares e Odontologia) desenvolvam mudanças curriculares. A Faculdade de Ciências Médicas não modificou sua estrutura curricular; ela se debate com problemas financeiros e de organização interna da docência e da prestação de serviços.

\section{Regulamentaçōes}

A rede universitária é a que permite, em nível nacional, a outorga de títulos profissionais. Ambas as universidades (Nacional e Católica) possuem estatutos e regulamentos para sua organização e funcionamento.

Existe uma tendência à abertura de novas escolas de formação em saúde. Há dez anos foi criada no interior do país, visando a descentralização, a Faculdade de Ciências Médicas de Villarrica, da Universidade Católica. Mais recentemente, foram criadas uma Faculdade de Odontologia e, para outras profissões, como Enfermagem, abrem-se instituições de formação técnica terciária. O pessoal técnico é formado basicamente pelo MSPBS.

Não existem, nacionalmente, nem espaços nem mecanismos de avaliação integral ou controle social da educação em saúde.

\section{Serviço Social}

A FCM estabeleceu um internato rotatório obrigatório nas quatro especialidades básicas em serviços da área metropolitana, com um estágio rural. Houve, em anos recentes, uma mobilização de estudantes contra a obrigato- 
riedade do serviço social, invocando-se questões de remuneração, condições programáticas e de supervisão etc.

A licenciatura em Enfermagem estabelece um serviço social melhor aceito por prestadores e estudantes.

\section{DISTRIBUIÇÃO GEOGRÁFICA}

O Censo Nacional de 1985 mostra a grande concentração dos Recursos Humanos em saúde na capital e grandes cidades. No caso dos médicos, quase $80 \%$ desenvolvem sua prática na área metropolitano de Assunção. A Região Oriental (Ciudad del Este, Encarnación e Medio Oriental) é polo de atração no interior. A Região Ocidental, com baixa densidade populacional, déficit de estradas, aridez e temperaturas elevadas, beneficia-se apenas de serviços militares de assistência.

Em Odontologia, a concentração é semelhante para os dentistas $(80 \%$ estão na área metropolitana), enquanto $62 \%$ dos técnicos encontram-se no interior.

O pessoal de enfermagem de nível superior tem $81 \%$ concentrado na área da capital, que acolhe também $45,5 \%$ do pessoal auxiliar. A enfermagem obstétrica (niveis técnico e auxiliar) tem apenas $29 \%$ do pessoal na capital, pois o mercado de melhor inserção encontra-se no interior. Quanto ao pessoal técnico, $52,8 \%$ encontra-se na capital, o mesmo ocorrendo com pessoal de farmácia.

Não existem estudos sobre migração interna de profissionais, embora se possa inferir que Assunção é pólo de atração demográfica poderoso, tanto para a formação e a capacitação, quanto para o exercício profissional.

\section{CONTROLE DO EXERCÍCIO PROFISSIONAL E DAS ESPECIALIDADES}

O controle das profissões ou ocupações em nível nacional, em especial a regulação do exercício profissional, inclusive dos níveis técnico e auxiliar, está enunciado no Código Sanitário.

O controle do exercício da prática médica está a cargo do Ministério da Saúde, através do Departamento de Controle Profissional que estabelece os requisitos básicos para a habilitação para o exercício profissional de médicos técnicos e auxiliares. O Departamento conta com uma organização mínima, com um chefe que é advogado e uma composição não situada na estrutura de gestão de recursos humanos, o que limita sua ação.

Os procedimentos para a habilitação são simples. Para médicos nacionais, consiste apenas na apresentação do título original e fotocópia, documento de identidade e pagamento de taxa de cerca de US $\$ 22,00$.

No caso de formados no exterior, intervém na habilitação a Reitoria da Universidade Nacional de Assunção, que revalida o título (custo de US\$ 
$550,00)$, em trâmite que dura entre 3 meses e 1 ano e que exige, além disso, documentação de imigração e visto de residência de 1 ano, índice analítico de matérias, certificado de ética do país de origem e a taxa de US $\$ 22,00$ do Ministério da Saúde.

Em ambos os casos, a duração da habilitação é de cinco anos, com renovação exigida ao final deste período.

Os médicos estrangeiros habilitados provêm principalmente da Argentina, Brasil, Peru, Bolívia, Chile e Uruguai. Alguns profissionais nacionais realizam sua formação de pós-graduação em países latino-americanos, Estados Unidos ou em países europeus, como Espanha, França, Bélgica e Alemanha.

No caso de médicos oriundos de países asiáticos (China, Coréia etc.), exige-se informações curriculares minudentes, ficando a revalidação por conta da Universidade Nacional. Para profissionais de Bioquímica, Psicologia e Odontologia exige-se o mesmo procedimento.

Com respeito a técnicos e auxiliares, reconhece-se uma ampla e variada gama de ocupações em saúde, como técnicos em Radiologia, Odontologia, Laboratório, Enfermagem, Obstetrícia, Hemoterapia, Anestesia, Fisiatria, Massagem, Ótica, Podologia etc. Nestes casos a validação do título é feita pelo Ministério das Relações Exteriores e não pelo Ministério da Saúde.

Mais recentemente, o Departamento de Controle Profissional vem intervindo na regulamentação de ocupações, tendo regulado o exercício dos óticos. É importante notar que existe, no país, um amplo mercado de óticas em crescimento, pelo que conjuntamente a Associação de Óticas do Paraguai e o Ministério da Saúde regulamentaram o exercício desta ocupação.

Com respeito à regulação e controle das espeçialidades médicas, está em tramitação no Poder Legislativo - aguardando sanção da Câmara dos Deputados - a Lei da Colegiação Médica, que regulará a especialização médica. A causa da demora é o artigo que trata da obrigatoriedade da colegiatura.

O Conselho Nacional de Saúde e, dentro deste, o Comitê Nacional de Recursos Humanos, convocou o Sindicato Médico, Sociedades Científicas, Faculdade de Medicina e a Coordenação do Ministério da Saúde para delimitar e regulamentar a especialização médica, em especial o processo de formação e a acreditação de especialidades básicas.

É provável que a médio e longo prazo, com a aprovação da nova Constituição, as leis do Código Sanitário e da Colegiação sejam modificadas, buscando coerência com a Carta Magna nacional.

É incipiente, mas progressivo, que as associações científicas e sindicais intervenham na questão dos especialistas, o que facilitará o reconhecimento entre seus pares, bem como a elaboração de pauta para tal. 


\section{ESQUEMAS E DISPOSITIVOS INFORMAIS DE NEGOCIAÇÃO DE CONFLITOS}

As associações de organização de interesses em nível das profissões e/ou ocupações em saúde têm estado fortemente condicionados pelos momentos históricos vividos pelo país.

Os 35 anos do regime patrimonialista não permitiram a associação e/ou sindicalização livre dos funcionários nacionais do setor saúde, mas sim a tutela pelo Estado. Apesar disso e da existência da lei do funcionário público, os profissionais se organizaram em nível das instituições provedoras de serviços. Em alguns casos, foram focos de resistência ao regime do General Stroessner, no que cabe mencionar, particularmente, o Hospital de Clínicas (Universidade) e outros. Os mecanismos associativos lideraram a mobilização em resistência ao regime.

Depois do Golpe de Estado de três de fevereiro de 1989 e das eleições, o país encaminha-se para um governo de transição, com liberdades de expressão e associação, embora tenha sido lenta a retirada dos obstáculos jurídicos à associação.

Observa-se, neste período, a tendência ao estabelecimento de associações gremiais (em hospitais públicos), por profissões (médicos, enfermeiros, bioquímicos etc.), tendo sido constituída a Federação de Profissionais de Saúde.

A nova Constituição explicita, no artigo 96, o direito à organização em sindicatos, sem autorização prévia. As ações políticas neste período foram orientadas para obter reinvidicações setoriais (salariais, de condições de trabalho, plano de cargos etc.) 



\section{Aneros}

\section{Tratado para a Constituição de um Mercado Comum entre a Argentina, o Brasil, o Paraguai e o Uruguai}

A República Argentina, a República Federativa do Brasil, a República do Paraguai e a República Oriental do Uruguai, doravante denominados "Estados Partes";

Considerando que a ampliação das atuais dimensões de seus mercados nacionais, através da integração, constitui condição fundamental para acelerar seus processos de desenvolvimento econômico com justiça social;

Entendendo que esse objetivo deve ser alcançado mediante o aproveitamento mais eficaz dos recursos disponíveis, a preservação do meio ambiente, o melhoramento das interconexões físicas, a coordenação de políticas macroeconômicas da complementação dos diferentes setores da economia, com base nos princípios de gradualidade, flexibilidade e equilíbrio;

Tendo em conta a evolução dos acontecimentos internacionais, em especial a consolidação de grandes espaços econômicos, e a importância de lograr uma adequada inserção internacional para seus países;

Expressando que este processo de integração constitui uma resposta adequada a tais acontecimentos;

Conscientes de que o presente Tratado deve ser considerado como um novo avanço no esforço tendente ao desenvolvimento progressivo da integração da América Latina, conforme o objetivo do Tratado de Montevidéu de 1980; 
Convencidos da necessidade de promover o desenvolvimento científico e tecnológico dos Estados Partes e de modernizar suas economias para ampliar a oferta e a qualidade dos bens de serviços disponíveis, a fim de meIhorar as condições de vida de seus habitantes;

Reafirmando sua vontade política de deixar estabelecidas as bases para uma união cada vez mais estreita entre seus povos, com a finalidade de atcançar os objetivos supramencionados;

Acordam:

\section{Capítulo I \\ Propósito, Princípios e Instrumentos}

Artigo $1^{\mathbf{Q}}$ - Os Estados Partes decidem constituir um Mercado Comum, que deverá estar estabelecido a 31 de dezembro de 1994, e que se denominará "Mercado Comum do Sul" (MERCOSUL).

Este Mercado Comum implica:

A livre circulação de bens, serviços e fatores produtivos entre os países, através, entre outros, da eliminação dos direitos alfandegários e restrições não-tarifárias à circulação de mercado de qualquer outra medida de efeito equivalente;

O estabelecimento de uma tarifa externa comum e a adoção de uma política comercial comum em relação a terceiros Estados ou agrupamentos de Estados e a coordenação de posições em foros econômico-comerciais regionais e internacionais;

A coordenação de políticas macroeconômicas e setoriais entre os Estados Partes - de comércio exterior, agrícola, industrial, fiscal, monetária, cambial e de capitais, de serviços, alfandegária, de transportes e comunicações e outras que se acordem -, a fim de assegurar condições adequadas de concorrência entre os Estados Partes; e

O compromisso dos Estados Partes de harmonizar suas legislações, nas áreas pertinentes, para lograr o fortalecimento do processo de integração.

Artigo $2^{\mathbf{0}}$ - O Mercado Comum estará fundado na reciprocidade de direitos e obrigações entre os Estados Partes.

Artigo $3^{\circ}$ - Durante o período de transição, que se estenderá desde a entrada em vigor do presente Tratado até 31 de dezembro de 1994, e a fim de facilitar a constituição do Mercado Comum, os Estados Partes adotam um Regime Geral de Origem, um Sistema de Solução de Controvérsias e Cláusulas de Salvaguarda, que constam como Anexos II, III e IV ao presente Tratado.

Artigo $4^{\circ}$ - Nas relações com terceiros países, os Estados Partes assegurarão condições eqüitativas de comércio. Para tal fim, aplicarão suas legislações 
nacionais, para inibir importações cujos preços estejam influenciados por subsídios, dumping ou qualquer outra prática desleal. Paralelamente, os Estados Partes coordenarão suas respectivas políticas nacionais com o objetivo de elaborar normas comuns sobre concorrência comercial.

Artigo $5^{\mathfrak{l}}$ - Durante o período de transição, os principais instrumentos para a constituição do Mercado Comum são:

a) um Programa de Liberação Comercial, que consistirá em reduções tarifárias progressivas, lineares e automáticas, acompanhadas da eliminação de restrições não-tarifárias ou medidas de efeito equivalente, assim como de outras restrições ao comércio entre os Estados Partes, para chegar a 31 de dezembro de 1994 com tarifa zero, sem barreiras não-tarifárias sobre a totalidade do universo tarifário (Anexo l);

b) a coordenação de políticas macroeconômicas, que se realizará gradualmente e de forma convergente com os programas de desgravação tarifária e eliminação de restrições não-tarifárias, indicados na letra anterior;

c) uma tarifa externa comum, que incentive a competitividade externa dos Estados Partes; $\mathrm{e}$

d) a adoção de acordos setoriais, com o fim de otimizar a utilização e mobilidade dos fatores de produção e alcançar escalas operativas eficientes.

Artigo $6^{0}$ - Os Estados Partes reconhecem diferenças pontuais de ritmo para a República do Paraguai e para a República Oriental do Uruguai, que constam no Programa de Liberação Comercial (Anexo I).

Artigo $7^{\mathbf{0}}$ - Em matéria de impostos, taxas e outros gravames internos, os produtos originários do território de um Estado Parte gozarão, nos outros Estados Partes, do mesmo tratamento que se aplique ao produto nacional.

Artigo $\mathbf{8}^{\mathbf{0}}$ - O Estados Partes se comprometem a preservar os compromissos assumidos até a data de celebração do presente Tratado, inclusive os Acordos firmados no âmbito da Associação Latino-Americana de Integração, e a coordenar suas posições nas negociações comerciais externas que empreendam durante o período de transição. Para tanto:

a) evitarão afetar os interesses dos Estados Partes nas negociações comerciais que realizem entre si até 31 de dezembro de 1994;

b) evitarão afetar os interesses dos demais Estados Partes ou os objetivos do Mercado Comum nos Acordos que celebrarem com outros países membros da Associação Latino-Americana de Integração durante o período de transição; 
c) realizarão consultas entre si sempre que negociem esquemas amplos de desgravação tarifária, tendentes à formação de zonas de livre comércio com os demais países membros da Associação Latino-Americana de Integração; e

d) estenderão automaticamente aos demais Estados Partes qualquer vantagem, favor, franquia, imunidade ou privilégio que concedam a um produto originário de ou destinado a terceiros países não-membros da Associação Latino-Americana de Integração.

\section{Capítulo II \\ Estrutura Orgânica}

Artigo $9^{0}$ - A administração e execução do presente Tratado e dos Acordos específicos e decisões que se adotem no quadro jurídico que o mesmo estabelece durante o período de transição estarão a cargo dos seguintes órgãos:

a) Conselho do Mercado Comum; e

b) Grupo do Mercado Comum.

Artigo $10^{\mathbf{0}}$ - O Conselho é o órgão superior do Mercado Comum, correspondendo-lhe a condução política do mesmo e a tomada de decisões para assegurar o cumprimento dos objetivos e prazos estabelecidos para a constituição definitiva do Mercado Comum.

Artigo $11^{2}$ - O Conselho estará integrado pelos Ministros de Relações Exteriores e os Ministros de Economia dos Estados Partes.

Reunir-se-á quantas vezes estime oportuno, e, pelo menos uma vez ao ano, o fará com a participação dos Presidentes dos Estados Partes.

Artigo $12^{\circ}$ - A Presidência do Conselho se exercerá por rotação dos Estados Partes e em ordem alfabética, por período de seis meses.

As reuniões do Conselho serão coordenadas pelos Ministérios de Relações Exteriores e poderão ser convidados a delas participar outros ministros ou autoridades de nível ministerial.

Artigo $13^{\circ}$ - O Grupo Mercado Comum é o órgão executivo do Mercado Comum e será coordenado pelos Ministérios das Relações Exteriores.

O Grupo Mercado Comum terá faculdade de iniciativa. Suas funções serão as seguintes:

velar pelo cumprimento do Tratado; 
- tomar as providências necessárias ao cumprimento das decisões adotadas pelo Conselho;

- propor medidas concretas tendentes à aplicação do Programa de Liberação Comercial, à coordenação de política macroeconômica e à negociação de Acordos frente a terceiros; $\mathrm{e}$

- fixar programas de trabalho que assegurem avanços para o estabelecimento do Mercado Comum.

O Grupo Mercado Comum poderá constituir os Subgrupos de TrabaIho que forem necessários para o cumprimento de seus objetivos. Contará inicialmente com os Subgrupos mencionados no Anexo V.

$O$ Grupo Mercado Comum estabelecerá seu regime interno no prazo de sessenta (60) dias de sua instalação.

Artigo $14^{\circ}$ - O Grupo Mercado Comum estará integrado por quatro membros titulares e quatro membros alternos por país, que representem os seguintes órgãos públicos:

- Ministério das Relações Exteriores;

- Ministério da Economia ou seus equivalentes (áreas de indústria, comércio exterior e/ou coordenação econômica); e

- Banco Central.

Ao elaborar e propor medidas concretas no desenvolvimento de seus trabalhos, até 31 de dezembro de 1994, o Grupo Mercado Comum poderá convocar, quando julgar conveniente, representantes de outros órgãos da Administração Pública e do setor privado.

Artigo $15^{\mathbf{0}}$ - O Grupo Mercado Comum contará com uma Secretaria Administrativa cujas principais funções consistirão na guarda de documentos e comunicações de atividade do mesmo. Terá sua sede na cidade de Montevidéu.

Artigo $16^{\circ}$ - Durante o período de transição, as decisões do Conselho do Mercado Comum e do Grupo Mercado Comum serão tomadas por consenso e com a presença de todos os Estados Partes.

Artigo $17^{\circ}$ - Os idiomas oficiais do Mercado Comum serão o português e o espanhol e a versão oficial dos documentos de trabalho será a do idioma do país sede de cada reunião.

Artigo $18^{\circ}$ - Antes do estabelecimento do Mercado Comum, a 31 de dezembro de 1994, os Estados Partes convocarão uma reunião extraordinária com o objetivo de determinar a estrutura institucional definitiva dos órgãos 
de administração do Mercado Comum, assim como as atribuições específicas de cada um deles e seu sistema de tomada de decisões.

\section{Capítulo III \\ Vigência}

Artigo $19^{\circ}$ - O presente Tratado terá duração indefinida e entrará em vigor trinta (30) dias após a data do depósito do terceiro instrumento de ratificação. Os instrumentos de ratificação serão depositados ante o Governos dos demais Estados Partes. O Governo da República do Paraguai notificará ao Governo de cada um dos demais Estados Partes a data de entrada em vigor do presente Tratado.

\section{Capítulo IV}

\section{Adesão}

Artigo $\mathbf{2 0}^{\mathbf{0}}$ - O presente Tratado estará aberto à adesão, mediante negociação, dos demais países membros da Associação Latino-Americana de Integração, cujas solicitações poderão ser examinadas pelos Estados Partes depois de cinco (5) anos de vigência deste Tratado.

Não obstante, poderão ser consideradas antes do referido prazo as solicitações apresentadas por países membros da Associação Latino-Americana de Integração que não façam parte de esquemas de integração sub-regional ou de uma associação extra-regional.

A aprovação das solicitações será objeto de decisão unânime dos Estados Partes.

\section{Capítulo V \\ Denúncia}

Artigo $21^{\circ}$ - O Estado Parte que desejar desvincular-se do presente Tratado deverá comunicar essa intenção aos demais Estados Partes de maneira expressa e formal, efetuando no prazo de sessenta (60) dias a entrega do documento de denúncia ao Ministério das Relações Exteriores da República do Paraguai, que o distribuirá aos demais Estados Partes.

Artigo $2^{\circ}$ - Formalizada a denúncia, cessarão para o Estado denunciante os direitos e obrigaçōes que correspondam à sua condição de Estado Parte, mantendo-se os referentes ao programa de liberação do presente Tratado e outros aspectos que os Estados Partes, juntos com o Estado denunciante, acordem no prazo de sessenta (60) dias após a formalização da denúncia. Esses direitos e obrigações do Estado denunciante continuarão em vigor por um período de dois (2) anos a partir da data da mencionada formalização. 


\section{Capítulo VI \\ Disposições Gerais}

Artigo 23ํㅡ - O presente Tratado se chamará "Tratado de Assunção".

Artigo $24^{\circ}$ - Com o objetivo de facilitar a implementação do Mercado Comum, estabelecer-se - á Comissão Parlamentar Conjunta do MERCOSUL. Os Poderes Executivos dos Estados Partes manterão seus respectivos Poderes Legislativos informados sobre a evolução do Mercado Comum, objeto do presente Tratado.

Feito na cidade de Assunção, aos 26 dias do mês de março de mil novecentos e noventa e um, em um original, nos idiomas português e espanhol, sendo ambos os textos igualmente autênticos. O Governo da República do Paraguai será o depositário do presente Tratado e enviará cópia devidamente autenticada do mesmo aos Governos dos demais Estados Partes signatários e aderentes.

Pelo Governo da República Argentina

Carlos Saul Menem

Guido Di Tella

Pelo Governo da República Federativa do Brasil

Fernando Collor

Francisco Rezek

Pelo Governo da República do Paraguai

Andres Rodrigues

Alexis Frutos Vaesken

Pelo Governo da República Oriental do Uruguai

Luis Alberto Lacalle Herrera

Hector Gros Espiell

\section{Regulamento da Comissão Parlamentar Conjunta do MERCosuL}

Em Montevidéu, capital da República Oriental do Uruguai, no dia 6 de dezembro de 1991, na Sala das Sessões da Assembléia Geral, as delegações de parlamentares da República Argentina, da República Federativa do Brasil, da República do Paraguai e da República Oriental do Uruguai, integrantes dos Estados Partes signatários do Tratado de Assunção, declaram formalmente aprovado o Regulamento da Comissão Parlamentar Conjunta do MERCOSUL e proclamam a sua vontade inequívoca de dar ao processo de integração, iniciado por seus respectivos países, o apoio que surge da representação emanada da soberania popular.

Os representantes dos Parlamentos dos Estados signatários do Tratado de Assunção que cria o Mercado Comum do Sul, com o propósito de: 
- estabelecer a união cada vez mais estreita entre os povos do sul da América, a partir da nossa região;

- garantir mediante uma ação comum o progresso econômico e social, eliminando as barreiras que dividem nossos países e nossos povos;

- favorecer as condições de vida e emprego, criando condições para um desenvolvimento auto-sustentável que preserve nosso entorno e que se construa em harmonia com a natureza;

- salvaguardar a paz, a liberdade, a democracia e a vigência dos direitos humanos;

- fortalecer o espaço parlamentar no processo de integração, com vistas à futura instalação do Parlamento do MERCOSUL; e

- apoiar a adesão dos demais países latino-americanos ao processo de integração e suas instituições.

Resolvem aprovar o seguinte Regulamento.

Artigo $1^{0}$ - Fica estabelecida a Comissão Parlamentar Conjunta do MERCosul, conforme determina o Artigo $24^{\circ}$ do Tratado de Assunção, assinado em 26 de março de 1991, entre os Governos da República Argentina, República Federativa do Brasil, República do Paraguai e República Oriental do Uruguai, que se regerá por este Regulamento.

\section{Dos Membros e sua Composição}

Artigo $2^{\mathbf{Q}}$ - A Comissão será integrada por até sessenta e quatro (64) parlamentares de ambas as Câmaras; até dezesseis (16) de cada Estado Parte, e igual número de suplentes, que serão designados pelos respectivos Parlamentos nacionais, de acordo com seus procedimentos internos.

A duração do mandato de seus integrantes será determinada pelos respectivos Parlamentos, desde que este não seja inferior a dois anos, com o intuito de favorecer a necessária continuidade.

A Comissão só poderá ser integrada por parlamentares no exercício do seu mandato.

\section{Funções e Atribuições}

Artigo $3^{\mathbf{0}}$ - A Comissão terá caráter consultivo, deliberativo e de formulação de propostas.

Suas atribuições serão:

a) acompanhar a marcha do processo de integração regional expresso na formação do Mercado Comum do Sul - MERCOSUL - e informar os congressos nacionais a esse respeito; 
b) desenvolver as ações necessárias para facilitar a futura instalação do Parlamento do MERCOSUL;

c) solicitar aos órgãos institucionais do MERCOSUL, informações a respeito da evolução do processo de integração, especialmente no que se refere aos planos e programas de ordem política, econômica, social e cultural;

d) constituir Subcomissões para a análise dos temas relacionados com o atual processo de integração;

e) emitir recomendações sobre a condução do processo de integração e da formação do Mercado Comum, as quais poderão ser encaminhadas aos órgãos institucionais do MERCOSUL;

f) realizar os estudos necessários à harmonização das legislações dos Estados Partes, propor normas de direito comunitário referentes ao processo de integração e levar as conclusões aos Parlamentos nacionais;

g) estabelecer relações com entidades privadas nacionais e locais, com entidades e organismos internacionais e solicitar informação e o assessoramento que julgue necessário sobre assuntos do seu interesse;

h) estabelecer relações de cooperação com os Parlamentos de terceiros países e com outras entidades constituídas no âmbito dos demais esquemas de integração regional;

i) subscrever acordos sobre cooperação e assistência técnica com organismos públicos e privados, de caráter nacional, regional, supranacional e internacional;

j) aprovar o orçamento da Comissão e gestionar ante os Estados Partes o seu funcionamento; $\mathrm{e}$

k) sem prejuízo dos itens anteriores, a Comissão poderá estabelecer outras atribuições dentro do marco do Trabalho de Assunção.

\section{Das Subcomissões}

Artigo $4^{0}$ - Criam-se as seguintes Subcomissões:

1. de Assuntos Comerciais;

2. de Assuntos Aduaneiros e Normas Técnicas;

3. de Políticas Fiscais e Monetárias;

4. de Transporte;

5. de Política Industrial e Tecnológica;

6. de Política Agrícola;

7. de Política Energética;

8. de Coordenação de Políticas Macroeconômicas;

9. de Políticas Trabalhistas;

10. do Meio Ambiente;

11. de Relações Institucionais e Direito da Integração; e 
12. de Assuntos Culturais.

Outras Subcomissões poderão ser criadas, assim como suprimidas algumas existentes.

A Mesa Diretora fixará as competências das Subcomissões, mediante propostas das mesmas.

As Subcomissões se reunirão sempre que necessário para a preparação dos trabalhos. A participação dos parlamentares de cada Estado Parte nas Subcomissões terá o mesmo caráter oficial que a desempenhada na Comissão Parlamentar.

Artigo $5^{\mathbf{Q}}$ - Cada Subcomissão será integrada por dois (2) parlamentares de cada Estado Parte e seus suplentes. As Subcomissões elegerão suas próprias autoridades, seguindo os critérios estabelecidos no Artigo $16^{\circ}$.

\section{Das Reuniões}

Artigo $6^{0}$ - As reuniões da Comissão serão realizadas, em cada um dos Estados Partes, de forma sucessiva e alternada.

Ao Estado Parte onde se realize cada sessão ou reunião corresponderá a Presidência.

Artigo $7^{\mathbf{0}}$ - A Comissão se reunirá:

a) ordinariamente, pelo menos duas vezes ao ano, em data a ser determinada; e

b) extraordinariamente, mediante convocação especial assinada pelos quatro (4) Presidentes.

As convocações indicarão dia, mês, hora e local para a realização das reuniões, assim como a pauta a ser discutida, devendo a citação ser nominal, enviada com antecedência mínima de trinta (30) dias, mediante correspondência com registro postal, ou outro meio seguro.

Em caso de força maior, se uma reunião programada não puder ser realizada no país previsto, a Mesa Diretora da Comissão estabelecerá a sede alternativa.

Artigo $\mathbf{8}^{0}$ - Terão validade as sessões da Comissão com a presença das delegações parlamentares de todos os Estados Partes.

Convocada uma sessão, se um dos Estados Partes não puder comparecer por razões de força maior, os restantes poderão reunir-se, desde que para deliberar e decidir seja obedecido o disposto no Artigo 13 e.

Artigo $9^{0}$ - As sessões da Comissão serão públicas, exceto quando expressamente se decida pela sua realização em forma reservada. 
Artigo $10^{\circ}$ - As sessões serão abertas pelo Presidente da Comissão e o Secretário-Geral ou quem o substitua, conforme este regulamento.

Artigo $11^{\circ}$ - As sessões da Comissão serão iniciadas, salvo decisão em contrário, com a leitura e discussão da ata da reunião anterior que, uma vez aprovada, será assinada pelo Presidente e pelo Secretário-Geral.

Artigo $12^{\circ}$ - Nas atas das sessões devem constar as recomendações aprovadas pela Comissão.

Artigo $13^{\circ}$ - As decisões da Comissão serão tomadas por consenso das delegações de todos os Estados Partes, expressas pelo voto da maioria de seus integrantes acreditados pelos respectivos Parlamentos.

Artigo $14^{\mathfrak{Q}}$ - Os temas submetidos à consideração da Comissão serão distribuídos simultaneamente a quatro relatores, um por cada Estado Parte, os quais os estudarão a fim de emitir opinião a respeito. Os relatores disporão de um prazo comum de trinta (30) dias para emitir seus relatórios por escrito, que serão distribuídos às demais delegações da Comissão pelo menos quinze (15) dias antes da data de realização da sessão.

Artigo $15^{\circ}$ - Sobre a matéria apreciada, a Comissão poderá emitir recomendações, cuja forma final será objeto de deliberação de seus membros.

\section{Da Mesa Diretora}

Artigo $16^{\circ}$ - A Mesa Diretora será composta de quatro (4) Presidentes, pertencentes um a cada Estado Parte, que se alternarão a cada seis (6) meses, assim como de um (1) Secretário-Geral e três (3) Secretários alternos, também pertencentes um a cada Estado Parte que se alternarão da mesma forma. A Mesa Diretora será eleita em sessão ordinária para mandato de dois (2) anos.

Ao Presidente e a cada um dos três (3) Presidentes alternos corresponde um (1) Vice-Presidente, que pertencerá ao mesmo Estado Parte.

O Presidente e o Secretário-Geral devem pertencer ao mesmo Parlamento nacional.

A Presidência da Comissão poderá instituir um Grupo de Apoio Técnico, como órgão consultivo especial.

As autoridades serão eleitas pelos respectivos Parlamentos.

Artigo $17^{\circ}$ - No caso de vacância definitiva em qualquer das listas dos cargos da Mesa Diretora, a ocupação destes se efetuará por eleição na sessão seguinte àquela em que se deu vaga, salvo se faltarem menos de sessenta (60) dias para o término dos respectivos mandatos. 
Artigo $\mathbf{1 8}^{\mathbf{0}}$ - Em caso de vacância definitiva de um membro da Comissão, o grupo nacional tomará as devidas providências para a sua substituição por outro parlamentar, o qual cumprirá o mandato pelo período que restar.

Artigo $19^{\circ}$ - Ao Presidente da Comissão compete:

a) dirigir e ordenar os trabalhos da Comissão;

b) representar a Comissão;

c) dar conhecimento à Comissão de toda a matéria recebida;

d) designar relatores mediante proposta das delegações parlamentares, para as matérias a serem discutidas;

e) instituir grupos de estudo para o exame de temas apontados pela Comissão;

f) resolver as questões de ordem;

g) convocar as reuniões da Mesa Diretora e da Comissão e presidi-las;

h) assinar as atas, recomendações e demais documentos da Comissão;

i) gestionar doações, contratos de assistência técnica e outros sistemas de cooperação, gratuitamente, ante organismos públicos ou privados, nacionais e internacionais; $\mathrm{e}$

j) praticar todos os atos necessários ao bom desempenho das atividades da Comissão.

Artigo $20^{\circ}$ - Nos casos de ausência ou impedimento, o Presidente será substituído pelo respectivo Vice-Presidente.

Artigo $21^{\circ}$ - Ao Secretário-Geral da Comissão compete:

a) assistir a Presidência na condução dos trabalhos da Comissão;

b) atuar como secretário nas reuniões da Comissão e elaborar as respectivas atas;

c) preparar a redação final das recomendações da Comissão e sua tramitação;

d) custodiar e arquivar a documentação da Comissão; e

e) coordenar o funcionamento dos grupos de estudo instituídos.

Artigo $22^{\circ}$ - Os Secretários-Adjuntos assistirão o Secretário-Geral ou Alternos quando estes o solicitarem e os substituírem, assim como, nos casos de ausência, impedimento ou vacância.

A Comissão poderá criar uma Secretaria Permanente. 
Artigo $2^{0}$ - A Mesa Diretora terá poder executivo para instrumentar o estudo das políticas deliberadas pela Comissão. Terá ainda, a seu cargo, o relacionamento direto com os órgãos institucionais do MERCOSUL e transmitirá ao plenário da Comissão toda informação que receba destes.

\section{Das Disposições Gerais}

Artigo $24^{\varrho}$ - São idiomas oficiais da Comissão o espanhol e o português.

Artigo $25^{\circ}$ - Este regulamento entrará em vigor a partir da data de sua aprovação, ad referendum da ratificação dos Parlamentos dos Estados Partes cujas normas constitucionais assim o exijam.

\section{Anexo V}

\section{Subgrupos de Trabalho do Grupo Mercado Comum}

O Grupo Mercado Comum, para fins de coordenação das políticas macroeconômicas e setoriais, constituirá, no prazo de trinta (30) dias após sua instalação, os seguintes Subgrupos de Trabalho:

Subgrupo 1: Assuntos Comerciais

Subgrupo 2: Assuntos Aduaneiros

Subgrupo 3: Normas Técnicas

Subgrupo 4: Políticas Fiscal e Monetária Relacionadas com o Comércio

Subgrupo 5: Transporte Terrestre

Subgrupo 6: Transporte Marítimo

Subgrupo 7: Política Industrial e Tecnológica

Subgrupo 8: Política Agrícola

Subgrupo 9: Política Energética

Subgrupo 10: Coordenação de Políticas Macroeconômicas

\section{Nota:}

- Resolução MERCOSUL/GMC/RES. no 11/199 1(I), criou o Subgrupo de Trabalho $\mathrm{n}^{\mathrm{O}} 11$ - Assuntos Trabalhistas.

- Resolução MERCOSUL/GMC/RES. ne 11/199 2, modificou o nome do Subgrupo de Trabalho no 11 para Relações Trabalhistas, Emprego e Seguridade Social. 